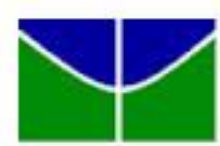

\title{
UnB
}

UNIVERSIDADE DE BRASÍLIA

FACULDADE DE EDUCAÇÃO

Programa de Pós-Graduação em Educação

Mestrado Profissional em Política Pública e Gestão da Educação Profissional e Tecnológica

DOCÊNCIA NA EDUCAÇÃO PROFISSIONAL E TECNOLÓGICA: INFLUÊNCIA DA FORMAÇÃO NO PROCESSO ENSINO-APRENDIZAGEM 


\title{
Rosilândia Ferreira de Aguiar
}

\section{DOCÊNCIA NA EDUCAÇÃO PROFISSIONAL E TECNOLÓGICA: INFLUÊNCIA DA FORMAÇÃO NO PROCESSO ENSINO-APRENDIZAGEM}

\begin{abstract}
Dissertação apresentada ao Programa de Pós-graduação em Educação-modalidade Mestrado Profissional da Universidade de Brasília-UnB, como requisito parcial para obtenção do Título de Mestre em Educação na Área de Concentração: Políticas Públicas e Gestão da Educação Profissional e Tecnológica e na Linha de Pesquisa: Formação de Professores.
\end{abstract}

Orientadora: Dra. Olgamir Francisco de Carvalho

\section{Brasília-DF}


Ficha catalográfica elaborada automaticamente, com os dados fornecidos pelo(a) autor(a)

Aguiar, Ronilandia Ferreira de

Docéncia na Bducação Profienional e Tecnol6gica: influencia da formaç̄o no procenso ensino aprendizagem / Roailandia Ferreira de Aguiar; orientador Olganir Prancieco de Carvalho. -Braailia, 2016.

$147 \mathrm{p}$.

Dismertaç̄̄o (Meatrado - Meatrado Profimsional en Educação) - Univeraidade de Brasflia, 2016.

1. Relação Bducaç̄̄o e Trabalho. 2. Caracterfinticas do Trabalhador do afculo XXI. 3. Pormaçäo e Docencia : dearion e realidades. 4. Trajet6ria hiet6rica da formaçäo docente para EPT. 5. Perfil docente e atuaç5̄ na BPT: novon preasuposton. I. Francisco de Carvalho, Olgamir, orient. II. Titulo. 


\section{DOCÊNCIA NA EDUCAÇÃO PROFISSIONAL E TECNOLÓGICA: INFLUÊNCIA DA FORMAÇÃO NO PROCESSO ENSINO-APRENDIZAGEM}

Banca Examinadora:

Profa. Dra. Olgamir Francisco de Carvalho (Orientadora) UnB/Faculdade de Educação

Profa. Dra. Maria da Conceição da Silva Freitas

UnB/Faculdade de Educação

Prof. Dr. Wilson Conciani

Instituto Federal de Brasília-IFB

Prof. Dr. Erlando da Silva Rêses

UnB/Faculdade de Educação

\section{Brasília}


Ao meu companheiro, Rômulo Lima, Aos meus filhos, Karolíney e Weslley de Aguiar Brasil, A minha neta, Karina Brasil 


\section{Agradecimentos}

É chegada a hora de agradecer a todos aqueles que estiverem ao meu lado na concretização de mais esta conquista em minha vida.

Agradeço, primeiramente, a Deus, por ter me dado força para persistir nessa jornada de estudos e proteção entre tantas idas e vindas à Universidade de Brasília.

À minha amiga Rêjane Andrade pela acolhida em Brasília.

Aos meus familiares e amigos, por muitas vezes, ter deixado de participar junto a eles de momentos de lazer em virtude de dedicar-me à realização desta conquista.

Ao meu companheiro Rômulo Lima pelo apoio e compreensão em todas as fases de realização deste estudo e, em nenhum momento, se ressentir da solidão.

Agradeço aos meus filhos, Karolíney e Weslley de Aguiar Brasil, pelo carinho, compreensão e pela constante força e orações para que concluísse este trabalho.

A minha netinha, Karina Brasil, apesar da pouca idade, cinco aninhos, mas de uma compreensão formidável pelos momentos que não pude estar com ela.

Agradeço, de forma especial, a Professora Olgamir Carvalho, por ter acreditado na proposta deste trabalho e, de forma segura, prestado a devida orientação.

Aos Professores da Pós-Graduação em Educação da UnB, especificamente do Mestrado Profissional, Berrnardo Kipnis, Remi Castioni, Olgamir Francisco de Carvalho e Albertina Mitjáns Martinez, pela forma proveitosa na condução das aulas.

Agradeço a gentileza dos professores Maria da Conceição, Wilson Conciani, Erlando Rêses por ter participado como membros avaliadores deste trabalho.

Agradeço aos colegas da turma do Mestrado Profissional que de forma unida e enriquecedora complementava essa formação com relatos e trocas constantes de experiências de vida e principalmente de atividades e ações desenvolvidas nos Institutos Federais.

Agradeço a gestão do IFPA/Campus Conceição do Araguaia por conceder autorização para realização desta pesquisa e aos docentes e discentes que aceitaram participar colaborando com informações que subsidiaram este estudo

Enfim, agradeço a todos os servidores da Instituição que contribuíram direta ou indiretamente para que este estudo fosse realizado.

Minha eterna Gratidão a todos! 


\section{Um Bom Professor, um bom começo}

A base de toda conquista é o professor

A fonte de sabedoria, o professor Em cada descoberta, cada invenção Todo bom começo tem um bom professor

No brilho de uma ferrovia (um bom professor) No bisturi da cirurgia (um bom professor)

No tijolo, na olaria, no arranque do motor Tudo que se cria tem um bom professor

No sonho que se realiza (um bom professor) Cada nova ideia tem um professor O que se aprende, o que se ensina (um professor)

Uma lição de vida, uma lição de amor

Na nota de uma partitura, no projeto de arquitetura

Em toda teoria, tudo que se inicia Todo bom começo tem um bom professor Tem um bom professor.

(Composição de Max Haetinger para o vídeo criado em 2011 para uma campanha de Valorização do Professor a pedido do Movimento Todos pela Educação) 


\section{RESUMO}

Este estudo propôs analisar a formação docente para atuação na Educação Profissional e Tecnológica (EPT) e a influência dessa formação no processo ensino-aprendizagem no âmbito dos cursos técnicos subsequentes no contexto de um Instituto Federal. Diante da Expansão da Rede Federal, a demanda por professores tem aumentado e observa-se diferentes perfis de formação dos docentes que estão atuando nos Institutos Federais que, em sua grande maioria, possuem o curso de bacharelado e qualificação a nível de mestrado e doutorado, sem formação voltada para o ensino. Esta pesquisa foi desenvolvida no Instituto Federal de Educação, Ciência e Tecnologia do Pará, Campus Conceição do Araguaia e teve uma abordagem qualitativa, caracterizada como um estudo de caso, realizada com os dois perfis de professores (licenciados e bacharéis) e também com alunos dos cinco cursos técnicos subsequentes. Utilizou-se para a coleta de dados vários instrumentos como análise documental, entrevistas e questionários. O referencial teórico perpassa de um recorte panorâmico dos principais acontecimentos históricos que marcaram a Educação Brasileira, aspectos da educação profissional como forma de buscar compreender suas origens e também desvelar as realidades e desafios no campo da docência e da formação, bem como, mergulhar na trajetória histórica de formação docente na EPT. A realidade do nosso país tem mostrado que ainda hoje não possui uma política pública consolidada de formação docente para atuação nesta modalidade da educação. Todavia, percebe-se que tem havido alguns debates e discussões nesse campo por pesquisadores que tem enveredado estudos sobre esta temática. Embora constate-se que nos próprios documentos legais exista indicações de formação de cunho emergencial, fragmentado e, por vez estanques que acabam não surtindo resultados efetivos na prática pedagógica. Neste novo tempo, àquela formação numa perspectiva disciplinar, fragmentada, sem estabelecer interação das ações e significações, com certeza, comprometerá a formação do profissional cidadão. Os dados indicaram que a maioria dos docentes, mesmo os licenciados, demostraram encontrar algumas limitações por se tratar da especificidade da EPT, para qual não obteve formação, mas, principalmente, a dificuldade se torna maior por parte dos bacharéis que nem sequer tiveram formação para atuarem no ensino. Portanto, isso nos faz perceber a necessidade de haver formação para os docentes que atuam na EPT, no sentido de capacitá-lo com o conhecimento específico da área, capacitá-los para atuar como docentes, com os saberes próprios da docência, metodologias diversificadas que favoreçam a transposição didática dos conteúdos bem como conhecimentos da área de psicologia educacional que lhes dê suporte para realizar a docência, superar os conflitos e sanar as dificuldades de aprendizagem de forma mais efetiva e significativa. No entanto, para quem está na docência, mas não obteve essa formação para trabalhar com a EPT, caberá à instituição promover a formação continuada proporcionando momentos de reflexão crítica para aprimoramento e aperfeiçoamento da prática pedagógica.

Palavras-chave: Educação Profissional e Tecnológica. Docência. Prática Pedagógica. 


\begin{abstract}
The present study proposes to examine teacher training to operate in Professional Education and Technology (EPT) and the influence of such training in the teaching-learning process in the context of subsequent technical studies within the context of a Federal Institute. Faced with the expansion of the Federal Network, the demand for teachers has waxed and observed different profiles of training of teachers who are working in the Federal Institutes that, for the most part, have the course Bachelor and qualification level of master's and doctorate, without training focused on teaching. This research was developed at the Federal Institute of Education, Science and Technology of Pará, Campus Conceição do Araguaia and had a qualitative approach, characterized as a case study, carried out with the two teachers profiles (graduates and graduates) and with students' following five technical courses. It was used for the collection of data several tools such as document analysis, interviews and questionnaires. The theoretical framework runs through a scenic cutout of the major events that shaped Brazilian Education, aspects of education as a way to try to understand their origin and also uncover the realities and challenges in the field of teaching and training, as well as diving in the trajectory history of teacher training in the EPT. The reality of our country has shown that it still does not have an established public policy of teacher training to work in this mode of education. However, it is clear that there has been some debate and discussion in the field by researchers who have delved into studies on this subject. Although it appears that in their own legal documents there, indications emergency nature of training, fragmented, and tight time that ends up not having effective results in teaching practice. At this new age, to that training in a disciplinary, fragmented perspective without setting interaction of actions and meanings surely undermine the formation of the professional citizen. The data indicated that the majority of teachers, even university graduates have shown find some limitations because it is the specificity of the EPT, for which did not get training, but mainly the difficulty becomes greater by the graduates who had not even trained to act in teaching. Therefore, it makes us perceive the need for training for teachers who work in EPT, to empower you with the specific knowledge of the area, enabling them to act as teachers with the teaching of own knowledge, diverse methodologies promote the didactic transposition of content and knowledge of educational psychology area to give them support to carry out teaching, overcome conflicts and counteract the difficulties of learning more effective and meaningful way. However, for those who are in teaching, but did not get this training to work with the EPT, it will be up to the institution to promote continuing education providing moments of critical reflection for improvement and improvement of pedagogical practices.
\end{abstract}

Keywords: Professional and Technological Education. Teaching. Pedagogical Practice. 


\section{LISTA DE ILUSTRAÇÕES}

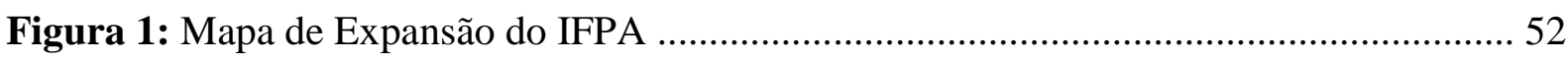

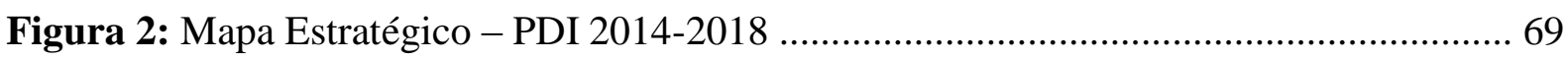

Figura 3: Layout criado do Laboratório Pedagógico....................................................... 126

\section{LISTA DE GRÁFICOS}

Gráfico 1: Faixa etária dos docentes do IFPA/CDA 65

Gráfico 2: Motivo da escolha do curso técnico pelos alunos 111

\section{LISTA DE QUADROS}

Quadro 1: Levantamento geral dos cursos ofertados no IFPA/CDA 53

Quadro 2: Demonstrativo de Matrículas dos cursos técnicos subsequentes 53

Quadro 3: Formação mínima exigida para o candidato a professor 62

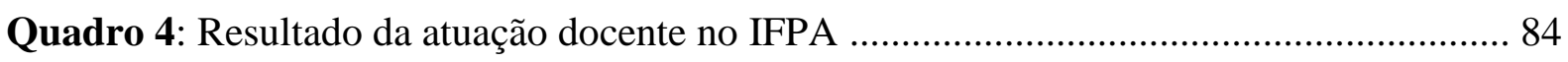

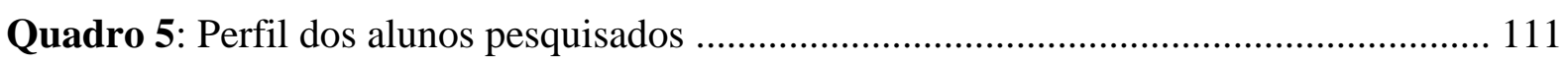

Quadro 6: Aspectos a serem analisados na percepção dos discente .................................. 112

\section{LISTA DE TABELAS}

Tabela 1: Cursos ofertados, matrícula e concluintes de 2001 a 2015 .................................... 54

Tabela 2: Perfil docente do IFPA/CDA (Formação inicial e Continuada) .............................66 


\section{LISTA DE ABREVIATURAS E SIGLAS}

CDA- Conceição do Araguaia

CEFET - Centro de Educação Federal e Tecnológica.

CGP - Coordenação de Gestão de Pessoas.

DCN - Diretriz Curricular Nacional

DCNs- Diretrizes Curriculares Nacionais

EBTT - Ensino Básico, Técnico e Tecnológico

EPT - Educação Profissional e Tecnológica

EPTNM - Educação Profissional Técnica de Nível Médio

IDH - Índice de Desenvolvimento Humano

IF - Instituto Federal de Educação, Ciência e Tecnologia

IFs - Institutos Federais de Educação, Ciência e Tecnologia

IFPA - Instituto Federal de Educação, Ciência e Tecnologia do Pará.

IFPA/CDA - Instituto Federal de Educação, Ciência e Tecnologia do Pará/Campus Conceição do Araguaia

PCN- Parâmetros Curriculares Nacionais

PDI - Plano de Desenvolvimento Institucional

PDC - Plano de Desenvolvimento do Campus

PPP - Projeto Político Pedagógico

PPC - Projeto Pedagógico do Curso

PPCs - Projetos Pedagógicos dos Cursos

PNE- Plano Nacional de Educação.

LDB - Lei de Diretrizes e Bases da Educação

LDBs - Leis de Diretrizes e Bases da Educação

LDBEN - Lei de Diretrizes e Bases da Educação Nacional

LP - Laboratório Pedagógico

TAE - Técnico em Assuntos Educacionais

TCLE - Termo de Consentimento Livre e Esclarecido

TPE -Todos pela Educação

UNESCO - Organização das Nações Unidas para a Educação, a Ciência e a Cultura.

RSC - Reconhecimento de Saberes e Competência 
INTRODUÇÃO .....................................................................................................................................12

1 EDUCAÇÃO BRASILEIRA E SUA CONTEXTUALIZAÇÃO HISTÓRICA .............16

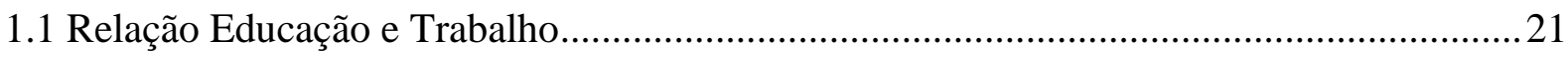

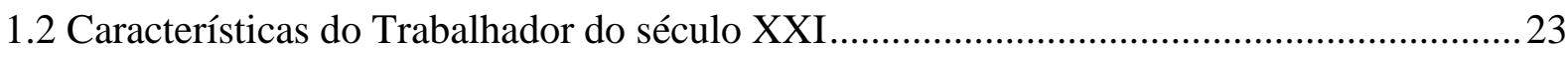

1.3 Educação Profissional e Tecnológica-EPT ……………………………………………....24

2 FORMAÇÃO E DOCÊNCIA： DESAFIOS E REALIDADES …......................................27

2.1 Trajetória histórica de formação docente para a EPT...........................................................32

2.2 Perfil docente e atuação na EPT: novos pressupostos.......................................................42

3 PROCEDIMENTOS METODOLÓGICOS DA PESQUISA................................................49

3.1 Caracterização da Instituição e Município - lócus da pesquisa ..............................................50

3.2 Sujeitos da pesquisa e Instrumentos de Coleta de dados ....................................................56

3.3 Procedimentos para a análise dos dados ............................................................................... 60

4 RESULTADOS E ANÁLISE DOS DADOS COLETADOS ................................................61

4.1 Exigência de Formação para compor o corpo docente.............................................................61

4.2 Dados do perfil e itinerário formativo dos docentes do IFPA/CDA ……………………....66

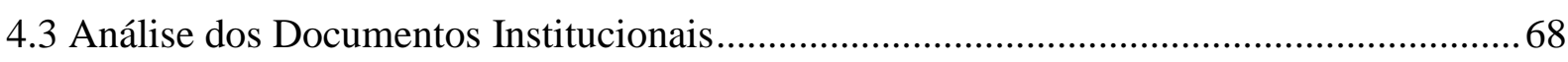

4.4 Dados e análise relativo às entrevistas com os docentes ...................................................... 73

4.5 Dados e análise da pesquisa realizada com os alunos dos cursos técnicos subsequentes 111

5 PRODUTO TÉCNICO .....................................................................................119

5.1 Laboratório Pedagógico: espaço de formação docente e integração de saberes .................119

5.2 Proposta de criação do Laboratório Pedagógico do IFPA/CDA...........................................123

CONSIDERAÇÕES FINAIS.......................................................................................................129 


\section{INTRODUÇÃO}

Esta pesquisa tem como objeto de estudo a formação docente para atuação na Educação Profissional e Tecnológica (EPT) e a influência dessa formação no processo de ensino-aprendizagem dos alunos dos cursos técnico subsequente do Instituto Federal de Educação, Ciência e Tecnologia do Pará/IFPA-Campus Conceição do Araguaia.

A escolha por esta temática se deu em relação aos desafios encontrados durante a nossa vivência profissional no Instituto Federal de Educação, Ciência e Tecnologia do Pará/IFPA-Campus Conceição do Araguaia, no qual sou concursada e efetivada, desde o ano de 2008, no cargo de Técnica em Assuntos Educacionais/TAE. Esta função tem nos proporcionado vivenciar diversas situações no cotidiano escolar que, a princípio, causou certo estranhamento, ou seja, embora a minha formação acadêmica seja em pedagogia, esta modalidade de ensino não foi contemplada durante esta formação.

Dessa forma, vislumbramos estudar e compreender melhor esse contexto da docência na EPT, ainda que se constate que em relação ao papel do professor, em linhas gerais e, no âmbito da educação propedêutica, respeitando suas especificidades e público alvo de cada modalidade de ensino, o papel do professor, o "como ensinar". De certa forma, tem uma peculiaridade semelhante, cuja função principal do professor se recai na promoção de uma mediação para que aconteça o aprendizado.

Entretanto, se faz oportuno salientar que na Educação Profissional, esse "ensinar" se constitui em uma dimensão mais ampla e por que não dizer que o mesmo assume uma conotação diferenciada, pois perpassa por um conjunto de desafios que exige dos professores saberes diversos relacionados à docência que, minimamente, perpassam pelo domínio de conteúdo específicos da área de atuação, metodologias diferenciadas para a transposição didática dos conteúdos e, além disso, noções de filosofia, antropologia, psicologia e sociologia cultural que lhes dê embasamento e favoreça a condução do seu trabalho pedagógico, bem como estar sintonizado com as tendências do mundo do trabalho, acompanhar os avanços científicos e tecnológicos, da sua área de formação, como das áreas que possa vir atuar como docente na Instituição.

Nesse sentido e, diante da realidade nos Institutos Federais, o papel do professor se torna cada vez mais desafiador, pois ao ingressar nessas Instituições, o profissional possui uma atuação verticalizada, ou seja, o professor se inscreve no concurso público com probabilidade de atuação nos diversos cursos, pois o concurso se refere ao provimento de 
cargo efetivo da carreira de Magistério do Ensino Básico, Técnico e Tecnológico (EBTT). Em outras palavras, deixa claro que a atuação do professor se efetivará, de acordo com a oferta no Campus, dos diversos níveis de ensino (Ensino Básico, Técnico e Tecnológico). Isso, com certeza, vai exigir do professor saberes diferenciados e certa habilidade em promover um aprendizado mais amplo, os quais deverão agregar-se a formação acadêmica desses alunos à preparação para o mundo do trabalho. Diante disso, percebe-se que a EPT acontece em uma dimensão maior do que a educação exclusivamente propedêutica.

Ademais, no ano de 2012, em virtude do nosso trabalho na Instituição, tivemos a iniciativa de realizar um diagnóstico com os alunos que já haviam concluído os cursos técnicos subsequentes. Então, executou-se um projeto de pesquisa intitulado "Gestão dos Egressos do IFPA/CDA", cuja finalidade era obter um feedback sobre o grau de satisfação dos alunos, em relação ao ensino ofertado e dos conhecimentos adquiridos no IFPA/CDA.

Esta pesquisa mostrou um número significativo de alunos que considera que o ensino ficou a desejar pela ausência de aulas práticas, de laboratórios, visitas técnicas e equipamentos específicos da área técnica e, sobretudo, instrução, acompanhamento para a realização do estágio curricular obrigatório.

No ano de 2014, mediante o ingresso no Mestrado Profissional e, diante do que havíamos constatado nesta pesquisa, surgiu a oportunidade de estar refletindo mais detalhadamente sobre alguns aspectos e, decidiu-se, compreender melhor o perfil dos docentes de EPT do Campus Conceição do Araguaia, seu processo formativo, sua atuação e trajetória profissional bem como as práticas pedagógicas no ensino técnico subsequente.

Para nortear nossa compreensão, a princípio, partimos de alguns questionamentos: até que ponto a formação dos professores repercute no seu fazer pedagógico? As aulas são fundamentadas através de que referenciais metodológicos? Quais as concepções dos docentes e dos discentes em relação aos processos de ensino-aprendizagem? Responder a essas questões possibilitou uma compreensão de como se dão essas práticas e se as mesmas corroboram para atender as necessidades formativas de seus discentes.

Provavelmente, o fato dos professores possuírem uma formação inicial em nível de bacharelado e, somente esta formação, talvez faça com que eles encontrem dificuldades em realizar estratégias metodológicas diversificadas em sua prática pedagógica, relacionar a teoria com a prática de forma didática, considerando os perfis dos alunos e, portanto, ritmos de aprendizado diferentes.

Considerando a delimitação da pesquisa, a hipótese apresentada no parágrafo 
anterior, este estudo se orienta, basicamente, pela seguinte questão: Em que medida a formação do professor de Educação Profissional e Tecnológica influencia no processo ensino-aprendizagem de seus alunos, no âmbito dos cursos técnicos subsequentes do IFPACampus Conceição do Araguaia? Diante de tal questionamento, elaborou-se os seguintes objetivos que delineiam os estudos:

\section{Objetivo Geral:}

- Analisar a formação docente na Educação Profissional e Tecnológica e sua influência no processo de ensino-aprendizagem dos alunos do curso técnico subsequente no contexto do IFPA/CDA.

\section{Objetivos Específicos:}

- Construir o perfil de formação dos docentes do IFPA/CDA;

- Identificar a percepção dos docentes sobre a sua formação e as implicações na prática pedagógica;

- Analisar as repercussões das práticas pedagógicas no processo ensino-aprendizagem, conforme o perfil de formação docente;

- Identificar a percepção dos discentes sobre o processo ensino-aprendizagem

- Criar um Laboratório Pedagógico como espaço institucionalizado de formação docente e integração de saberes.

Esta dissertação está estruturada em cinco capítulos: No primeiro capítulo, faz-se um panorama dos principais acontecimentos que marcaram a Educação Brasileira do período colonial até o século XXI; aspectos da relação educação e trabalho; características do trabalhador do século XXI e também a definição, aspectos legais e pedagógicos sobre a Educação Profissional.

No segundo capítulo, aborda-se sobre os desafios e realidades da formação e docência; Trajetória histórica de formação docente para a Educação Profissional e Tecnológica e, por último, novos pressupostos do perfil docente e atuação na EPT.

O terceiro capítulo apresenta os procedimentos metodológicos da pesquisa: caracterização do município e da Instituição-lócus da pesquisa; Sujeitos, instrumentos de coleta de dados e os procedimentos utilizados para a análise. O quarto capítulo apresenta os resultados e a análise dos dados coletados. 
O quinto capítulo apresenta a proposição de um produto técnico derivado da revisão teórica e da análise dos dados coletados na pesquisa, isto é, uma sugestão de intervenção com um pequeno esboço de como poderá ser implementado pela gestão do Campus, a criação de um espaço institucional, denominado de "Laboratório Pedagógico". Esta sugestão de criar este espaço foi em decorrência dos resultados desta pesquisa onde todos os professores alegaram não possuir este momento de reflexão sobre sua prática pedagógica e, além disso, esse espaço será utilizado para realizações de formações contínuas mediante cursos de capacitações e aperfeiçoamentos, mesas redondas, discussões, entre outros, com o intuito de instrumentalizar ainda mais o fazer pedagógico dentro da instituição. Maiores detalhes no próprio capítulo.

Por fim, são apresentadas as considerações e as referências utilizadas que fundamentaram esta dissertação. 


\section{EDUCAÇÃO BRASILEIRA E SUA CONTEXTUALIZAÇÃO HISTÓRICA}

A educação brasileira, ao longo de sua trajetória histórica, tem passado por sucessivas reformas e mudanças, quase sempre decorrentes de momentos históricos impregnado de uma intencionalidade de adaptação às necessidades econômicas, políticas e sociais do país. Este é um fato que pode ser constatado desde quando iniciou a escolarização.

Os primeiros ensinamentos foram oferecidos pelos missionários católicos, que após sua chegada ao Brasil, em 1549, fundaram as escolas de primeiras letras, mas com a missão principal de formar sacerdotes, oferecendo instrução humanística à elite colonial, aos filhos dos colonos e, aos índios, foi oferecida a catequização. Aos habitantes primitivos da colônia portuguesa, no século XVI, a educação oferecida carregava uma intencionalidade primordial de doutrinação, de propagar os valores e a fé católica imposta pela Companhia de Jesus para formar novos adeptos ao Catolicismo, que estava ameaçado pela Reforma Protestante e, entre outras intenções, tornar o índio mais dócil para ser aproveitado como mão de obra.

Por vez, o modelo de educação durante a idade média, disseminou-se como um modelo de educação tradicional por ter perpassado por várias gerações e também pela característica desse ensino, o qual acontecia de forma autoritária, rígido e centrado na figura do professor - que, à época, era o senhor da verdade, não havendo clima de relação dialogada entre professor e alunos na construção do conhecimento e isso, nos leva a pensar que, esta postura se instalava para que exatamente não houvesse nenhuma argumentação contrária e ou questionadora de tais imposições. Transmitiram, segundo Azevedo (1963, p.93), "quase na sua integridade, o patrimônio de uma cultura homogênea, a mesma língua, a mesma religião, a mesma concepção de vida e os mesmos ideais de homem culto".

Seguindo esse raciocínio, o modelo de educação Jesuítica, conservadora, enciclopédica pautados nos dogmas da Igreja e elitista, foi prolongado por um período de mais de dois séculos - XVI e XVII e, não obstante, a educação brasileira possui uma herança cultural adquirida nessa sua raiz embrionária, que ainda hoje, em nossas escolas, observamos resquícios e questões que originam desta formatação inicial da nossa educação.

Com a expulsão dos Jesuítas, em 1759, pelo Marquês de Pombal, o governo Português passou a assumir a Educação, criando o ensino público, gratuito e laico. Porém, somente em 1772, foram de fato instituídas as escolas de aulas régias, para que fossem contratados os primeiros professores e esses passariam por um exame para demonstrar que sabiam ler, escrever, contar e um mínimo de doutrina cristã. 
Baseando na historiografia, podemos dizer que o perfil social desses primeiros professores se configurava como professores pobres e pessoas mais velhas que não tinham outra ocupação a fazer. Então, procuravam uma forma de ganhar algum dinheiro ensinando o básico: ler, escrever e contar. Outro fato também que nos chamou a atenção foi que, se não conseguiam passar nesses exames para ensinar nas escolas, davam aulas em suas próprias casas e cobravam o mínimo, como forma de ganhar algum dinheiro. Disso, podemos extrair que, desde muito cedo, houve uma certa desvalorização da profissão docente e uma certa separação estrutural no processo educativo. Nesse sentido, uma escola para a burguesia e outra para o povo.

Por outro lado, o século XIX foi permeado de muitos embates políticos, a começar pelo processo de independência do Brasil, o qual propiciou o poder das províncias que foram se constituindo. Foi nesse momento, que houve a elaboração da primeira constituição, em 1824, e nela foram reforçadas algumas peculiaridades normativas e, no caso da educação, a questão da institucionalização das escolas, contratação dos professores entre outras.

Em 15 de outubro de 1827, houve então a primeira Lei Geral de ensino, a qual passou a permitir as mulheres a participarem da instrução oferecidas nas escolas, porém, com ensinamentos diferenciados aos dos homens, ou seja, às mulheres destinava-se apenas o aprendizado da leitura, da escrita, doutrina e prendas domésticas, não cabiam a elas a instrução da matemática, apenas a contagem de alguns números.

Com o Ato Adicional de 1834, que foi uma emenda à constituição, foram introduzidas algumas mudanças significativas no processo educacional. Umas delas foi a questão da descentralização do ensino primário, passando às províncias a responsabilidade na sua condução do ensino, incluída aí a educação profissional e a responsabilização da formação dos professores. Ficando o ensino secundário e ensino superior a cargo do governo central. Segundo Saviani (2011):

[...] O Ato Adicional de 1834 teve o propósito de descentralizar a instrução primária conferindo maior grau de autonomia às províncias, o que lhes permitiria maior margem de criatividade e adequação da instrução às suas necessidades e características específicas. Mas não foi propriamente isso o que ocorreu (SAVIANI,2011, p.4).

Percebemos que mesmo com a autonomia conferida aos provincianos, nada foi alterado em relação à legislação para instrução pública, segundo Castanha (2007) "as províncias seguiram as orientações dos centros mais desenvolvidos, especialmente da Corte e Província do Rio de Janeiro, reproduzindo nas respectivas legislações provinciais os mesmos 
princípios e dispositivos do centro irradiador". Nesse contexto histórico, percebe-se que faltava, então, o Estado (nação) assumir a responsabilização pela educação de fato.

Já a partir do século XX, os rumos da educação brasileira passaram a ser discutidos por vários setores da sociedade organizada, que questionavam o tradicionalismo pedagógico imposto pela igreja e seguido nas escolas bem como a restrição do público atendido. Ou seja, o movimento da escola nova propôs uma nova estruturação da educação ao qual propunha a eliminação do dualismo escolar, dando oportunidades a todos participarem do processo de escolarização do elementar ao superior.

Em uma abordagem geral, podemos dizer que, o marco das mudanças introduzidas na área da educação emergiu com o manifesto dos pioneiros da educação nova, em 1932, o movimento escolanovista brasileiro, encampado pelos principais educadores da época ao qual tiveram a adesão de um total de 26 assinaturas nessa carta (sendo 23 de homens e 03 assinaturas de mulheres).

Os principais protagonistas desse movimento foram Anísio Teixeira, Francisco Campos, Fernando Azevedo, Cecília Meirelles que não só conclamavam para que tivesse oportunidades iguais a todas as classes, mas que houvesse uma estruturação da educação, mas uma estruturação renovada, voltada para a formação do cidadão como um todo e para a transformação da sociedade mesmo que para isso aglutinasse diferentes educadores católicos e liberais, conforme Vidal (2013) discrimina sua constituição:

\footnotetext{
[...] a Escola Nova constituiu-se no país como uma fórmula, com significados múltiplos e distintas apropriações produzidas no entrelaçamento de três vertentes: a pedagógica, a ideológica e a política.[...] Assim, o documento emergiu como parte do jogo político pela disputa do controle do Estado e de suas dinâmicas, e, portanto, como elemento de coesão de uma frente de educadores que, a despeito de suas diferenças, articulava-se em torno de alguns objetivos comuns, como laicidade, gratuidade e obrigatoriedade da educação. Ademais, ele também foi representante de um grupo de intelectuais que abraçava um mesmo projeto de nação, ainda que com divergências internas. (VIDAL, 2013, p. 577)
}

Vale ressaltar que foi nessa época que se deu a criação do Ministério dos Negócios da Educação e Saúde Pública (1930), criado pelo presidente Getúlio Vargas; a nova constituição 1934, estabelecendo além da gratuidade, a obrigatoriedade da educação elementar. Nessa época, também que se percebeu a necessidade de elaborar um Plano Nacional de Educação que implementasse diretrizes para uma educação renovada opondo-se à educação tradicional.

Saviani nos ajuda a compreender este novo processo da seguinte maneira: 
[...] a "Escola Nova" organizou-se basicamente na forma de escolas experimentais ou como núcleos raros, muito bem equipados e circunscritos a pequenos grupos de elite. No entanto, o ideário escolanovista, tendo sido amplamente difundido, penetrou nas cabeças dos educadores acabando por gerar consequências também nas amplas redes escolares oficiais organizadas na forma tradicional. Cumpre assinalar que tais consequências foram mais negativas que positivas uma vez que, provocando o afrouxamento da disciplina e a despreocupação com a transmissão de conhecimentos, acabou por rebaixar o nível do ensino destinado às camadas populares as quais muito frequentemente têm na escola o único meio de acesso ao conhecimento. Em contrapartida, a "Escola Nova" aprimorou a qualidade do ensino destinado às elites. (SAVIANI, 1985, p. 14).

Percebemos que houve investidas na maneira como o conhecimento era concebido e isso levou a propor um novo método de ensino, uma nova forma de aprender foi disseminada, mesmo que esta iniciativa tenha favorecido a uma camada da população não deixou de atingir outros setores da educação e instigou, de certa forma, ao marco da renovação no campo educacional.

Lourenço Filho elucida como se configura esta nova tendência pedagógica:

[...] aprende-se observando, pesquisando, perguntando, trabalhando, construindo, pensando e resolvendo situações problemáticas apresentadas, quer em relação a um ambiente de coisas, de objetos e ações práticas, quer em situações de sentido social e moral, reais ou simbólicos. (LOURENÇO FILHO, 1978, p. 151).

Diante do processo de industrialização que implantava no Brasil, houve, então, a necessidade de formar mão de obra para o mercado produtivo. Esse ciclo capitalista instalado fez com que a população da cidade fosse ampliada e o acesso à escola passou a ser uma necessidade para atender a lógica do mercado emergente.

Diante da primeira revolução industrial, as máquinas passaram a ser o centro do processo produtivo, onde os trabalhos que antes eram feitos manualmente, mas que demandavam tempo e esforço físico, passaram a ser executados pelas máquinas com um certo grau de precisão e rapidez. Consequentemente, houve ampliação do número de pessoas desempregadas. Podemos sintetizar que foi a partir daí que o trabalho humano intelectual passou a se desenvolver articulado com as máquinas e a escola assume essa responsabilidade de formar pessoas críticas, criativas, inteligentes, e inovadoras para atuar produtivamente neste novo contexto.

Por outro lado, o inadmissível, nestes tempos modernos, seria a perpetuação da passividade, a reprodução. O processo ensino-aprendizagem nesse século XXI exige pessoas pensantes e criativas, com espírito empreendedor e coletivo e com capacidade para 
compreender e conviver com a diversidade cultural e, obviamente, a formação conteudista ou mesmo fragmentada por disciplinas que não dialogam entre si, não conseguirá formar esse novo cidadão. Segundo Rehem,

O quadro de transformações em processo no mundo do trabalho impõe novas exigências educacionais, requer um novo perfil de trabalhador para enfrentar os desafios. Neste novo cenário do mundo do trabalho, a educação tem papel preponderante a realizar, considerando as novas implicações da relação educaçãotrabalho, sobretudo no que se refere aos impactos sobre a relação entre educação e empregabilidade (REHEM, 2009, p. 51).

Sendo assim, convém que a educação, seja transformada e que seja assegurado aos alunos um conhecimento fundamentado nos quatro pilares da educação conforme descrito no período de (1992-1996) pela Comissão Internacional sobre Educação para o século XXI, relatório entregue a Organização das Nações Unidas para a Educação, a Ciência e a cultura UNESCO denominado por "Educação: um tesouro a Descobrir", tendo como autor o economista e político francês Jacques Delors, que presidiu esta comissão internacional sobre a educação para o Século XXI. Os quatro pilares do conhecimento ficaram assim descritos no respectivo relatório da comissão:

\footnotetext{
Aprender a conhecer, combinando uma cultura geral, suficientemente ampla, com a possibilidade de estudar, em profundidade, um número reduzido de assuntos, ou seja: aprender a aprender, para beneficiar-se das oportunidades oferecidas pela educação ao longo da vida.

Aprender a fazer, a fim de adquirir não só uma qualificação profissional, mas, de uma maneira mais abrangente, a competência que torna a pessoa apta a enfrentar numerosas situações e a trabalhar em equipe. Além disso, aprender a fazer no âmbito das diversas experiências sociais ou de trabalho, oferecidas aos jovens e adolescentes, seja espontaneamente na sequência do contexto local ou nacional, seja formalmente, graças ao desenvolvimento do ensino alternado com o trabalho.

Aprender a conviver, desenvolvendo a compreensão do outro e a percepção das interdependências - realizar projetos comuns e preparar-se para gerenciar conflitos - no respeito pelos valores do pluralismo, da compreensão mútua e da paz.

Aprender a ser, para desenvolver, o melhor possível, a personalidade e estar em condições de agir com uma capacidade cada vez maior de autonomia, discernimento e responsabilidade pessoal. Com essa finalidade, a educação deve levar em consideração todas as potencialidades de cada indivíduo: memória, raciocínio, sentido estético, capacidades físicas, aptidão para comunicar-se (DELORS, 2010, p.31, grifos meus).
}

Dentro do contexto pedagógico, os quatros fundamentos da educação para este século XXI devem caminhar juntos, eles se complementam, existem entre eles uma conexão recíproca, de relacionamento e permuta que, faz o conhecimento do ser humano ser a base para seu desenvolvimento no decorrer de sua vida.

Historicamente, nesta mesma linha de raciocínio e, na condição de estabelecer novas práticas pedagógicas para uma educação transformadora, em setembro de 2010 houve a Conferência Internacional sobre os Sete Saberes necessários à Educação do Presente que 
perpassam por processos formativos que contemplem em seus ensinamentos tais saberes: (As cegueiras do conhecimento: o erro e a ilusão; Princípios do conhecimento pertinente; ensinar a condição humana; ensinar a identidade terrena; enfrentar as incertezas; ensinar a compreensão; à ética do gênero humano) E, por quatro dias em Fortaleza, Ceará, foram debatidos inspirados na obra do filósofo, sociólogo, historiador, francês Edgar Morin e surgiram alguns consensos e recomendações importantes às instituições educacionais, professores e alunos que servem de inspirações para formação na sociedade atual:

[...] é importante ter o pensamento complexo, ecologizado, capaz de relacionar, contextualizar e religar diferentes saberes ou dimensões da vida. A humanidade precisa de mentes mais abertas, escutas mais sensíveis, pessoas responsáveis e comprometidas com a transformação de si e do mundo. [...]. É fundamental criar espaços dialógicos, criativos, reflexivos e democráticos capazes de viabilizar práticas pedagógicas fundamentadas na solidariedade, na ética, na paz e na justiça social. [...] Uma educação que privilegie os Sete Saberes e seja pautada no desenvolvimento da compreensão e da condição humana, na cidadania planetária e na ética do gênero humano poderá colaborar para que os indivíduos possam enfrentar as múltiplas crises sociais, econômicas, políticas e ambientais que colocam em risco a preservação da vida no planeta.[...] uma educação transformadora que esteja centrada na condição humana, no desenvolvimento da compreensão, da sensibilidade e da ética, na diversidade cultural, na pluralidade de indivíduos, e que privilegie a construção de uma conhecimento transdisciplinar, envolvendo as relações indivíduo $\leftrightarrow$ sociedade $\leftrightarrow$ natureza. Esta é a condição fundamental para a construção de um futuro viável para as gerações presentes e futuras (MORIN, 2011, p. 13).

Notamos que, se faz necessário uma ruptura paradigmática transformadora na forma de conduzir o conhecimento dessas novas gerações. Um ensino tradicional, de práticas conservadoras, conduzido de forma fragmentada, na ordem inflexiva e rígida, já não atende ao processo de construção do conhecimento nem tão pouco colabora com a formação cidadã exigida na contemporaneidade.

\subsection{Relação Educação e Trabalho}

Antônio Gramsci (1891-1937), filósofo italiano, desde muito tempo, já vislumbrava uma escola que não separasse a formação geral clássica da formação profissional. Ele defendia que fosse uma escola unitária, sendo assegurada pelo Estado, que promovesse uma formação mais humana e ética, na medida em que não segregaria nenhuma classe e que todos tivessem oportunidade de estudar e que a autonomia fosse respeitada:

Para Gramsci a escola unitária é escola de trabalho intelectual e manual (técnico, industrial); que seu objetivo é a formação dos valores fundamentais do humanismo, isto é, a autodisciplina intelectual e a autonomia moral 
necessárias tanto para os estudos posteriores como para a profissão; que a instrução das novas gerações e das gerações adultas se apresentam sempre para ele como uma série contínua; que para ele nenhuma profissão está privada de conteúdos e exigências intelectuais e culturais, e ainda, que a vida moderna implica num novo entrelaçamento entre ciência e trabalho. (MANACORDA, 1990, p. 163)

Manfredi (2002) também nos ajuda a entender esta questão da relação da educação trabalho e escola na contemporaneidade da seguinte forma:

\begin{abstract}
$\mathrm{Na}$ sociedade contemporânea, as rápidas transformações do mundo do trabalho, o avanço tecnológico configurando a sociedade virtual e os meios de comunicação incidem fortemente na escola, aumentando os desafios para torná-la uma conquista democrática e efetiva. Transformar práticas e culturas tradicionais e burocráticas das escolas que, por meio da retenção e da evasão, acentuam a exclusão social, não é uma tarefa simples nem para poucos. $\mathrm{O}$ desafio é educar as crianças e os jovens, proporcionando-lhes um desenvolvimento humano, cultural, científico e tecnológico, de modo que adquiram condições para enfrentar as exigências do mundo contemporâneo. (MANFREDI, 2002, p.94).
\end{abstract}

Neste sentido, percebe que a questão da educação profissional se configura como um importante aspecto da vida social e educacional, ou seja, o trabalho entra na formação como princípio educativo.

Kuenzer (1989) também defende a superação do aprendizado profissional estreito e que seja promovida uma educação geral preparando o estudante para qualquer atividade que venha exercer durante sua vida futura.

Assim, já não se sustentam propostas pedagógicas que separam as funções intelectuais das funções técnicas: pelo contrário, o que se exige do homem moderno é uma formação que lhe permita captar, compreender e atuar na dinamicidade do real, enquanto sujeito político e produtivo que, potencialmente dirigente, tenha conhecimento científico e consciência de seus direitos e deveres para dominar a natureza e transformar as relações sociais. (KUENZER, 1989, p.24).

Diante do processo de transformação produtiva vivido nestes últimos tempos, se observa que a educação profissional institucionalizada assume tamanha responsabilidade para a qualificação e mudança de comportamento desse novo trabalhador, tanto na dimensão da formação de competências como também da própria constituição de sua cidadania.

Carvalho, (2003) ajuda a elucidar a questão quanto diz que:

Sem dúvida, a educação profissional é um produto do processo de modernização e, como tal, sempre esteve submetida à tensão entre as necessidades do mercado de trabalho e as exigências do desenvolvimento pessoal, todavia, do ponto de vista do novo paradigma técnico-econômico, é consensual o reconhecimento de que o 
conhecimento constitui uma variável importante na explicação das novas formas de organização social e econômica, o que sinaliza para uma questão fundamental, do ponto de vista da educação e dos educadores, quanto à importância histórica de se produzir e distribuir o conhecimento (CARVALHO, 2003, p. 90).

O binômio educação/trabalho e trabalho/educação nos faz pensar que essa é uma condição singular do homem. O trabalho como princípio educativo, pois o homem se autoconstrói pelo trabalho, ou seja, estamos falando de processos educativos, formativos que transformam a realidade pessoal e profissional e, consequentemente, esta transformação melhora sua sobrevivência bem como contribui para o desenvolvimento do país nos seus mais diversos setores.

Sendo assim, subentende que a Instituição que oferta curso profissionalizante oportunize um ensino de qualidade e que este ensino tenha uma estreita articulação com as demandas sociais, regionais, locais e esteja em sintonia com as rápidas transformações advindas dos avanços científicos e tecnológicos. Por isso, a responsabilidade da educação profissional se amplia, uma vez que ela precisa estar articulada com os diversos níveis e modalidades da educação e também com as dimensões do trabalho, da ciência, da tecnologia e da cultura.

Partindo desse pressuposto, a educação profissional tendo como eixo fundante a questão da profissionalização do indivíduo, deve-se preocupar em não somente ensinar conteúdo das disciplinas técnicas e específicas, mas sobretudo oportunizar uma educação integral, valorizar este ser humano, compreendendo este aluno como um cidadão que necessita de formação tecnológica, cientifica e cultural.

\subsection{Características do Trabalhador do século XXI}

A Organização das Nações Unidas para a Educação, Ciência e Cultura - UNESCO, referendou as principais características do trabalhador do século XXI, cujas características explicitadas se assemelham com as necessidades da educação para este século. E, uma delas, de cunho formativo, se refere à questão da flexibilidade, ou seja, a formação do cidadão deve ter uma caracterização flexível, considerando a rapidez das transformações ocorridas na sociedade como um todo, não se aconselha fazer sempre a mesma coisa ou da mesma forma.

O ser humano se diferencia dos outros animais, porque ele tem a capacidade de melhorar a qualidade de vida, desenvolver plenamente suas potencialidades, tomar decisões, de criar, de produzir conhecimentos e de aprender por toda a vida. Já dizia Jean Piaget (1896- 
1980) “a vida é um constante hábito de aprendizagem” e John Dewey (1859-1952) “a educação não é uma preparação para a vida e sim a própria vida".

Considerando as exigências do trabalhador neste mundo contemporâneo, as quais perpassam por requisitos fundamentais, ente eles, além da responsabilidade que deve estar no topo, criatividade, capacidade de iniciativa, postura empreendedora, capacidade de tomar decisão, entre outros. Tudo isso, com certeza, vai exigir postura responsável para intervir na realidade e, não obstante, a sociedade precisa juntamente com o Estado pensar de forma consciente e crítica, estabelecendo políticas públicas na formação dos cidadãos brasileiros. Logo, a qualidade dessa educação profissional ofertada necessita estar na ordem de prioridades e ou preocupações do governo e também da sociedade como um todo.

\subsection{Educação Profissional e Tecnológica-EPT}

No século passado, a educação profissional, possuía uma denominação diferente, a qual era denominada de formação profissional, que, segundo Militao (2010, p. 133), citado por Ferreti (2010), enfatiza o "saber fazer" ao passo que a educação profissional dos tempos modernos valoriza, em tese, "a formação integral do profissional".

No Brasil, a denominação de educação profissional, é recente, segundo Ferreti (2010, p. 1) “A educação profissional refere-se aos processos educativos que tem por finalidade desenvolver formação teórica, técnica e operacional que habilite o indivíduo ao exercício profissional de uma atividade produtiva".

No âmbito legal, a Educação Profissional está caracterizada como uma modalidade educacional que, articulada com as diferentes formas de educação, conduz o cidadão ao "permanente desenvolvimento de aptidões para a vida produtiva" (Lei n 11.741/2008 alterou os dispositivos da LDB, $\mathrm{n}^{\circ}$ 9.394/96).

Assim, em seu artigo 39, a LDB 9.394/96, define a Educação Profissional Técnica e Tecnológica da seguinte forma: “A educação profissional e tecnológica, no cumprimento dos objetivos da educação nacional, integra-se aos diferentes níveis e modalidades de educação e às dimensões do trabalho, da ciência e da tecnologia”.

Nesse contexto, os currículos das escolas de educação profissional devem contemplar a preparação para a vida como um todo, a formação integral do ser humano, articulando os diversos saberes, contemplando transdisciplinarmente em seus ensinamentos "permanente desenvolvimento de aptidões para a vida produtiva" (BRASIL, 1996). 
A educação profissional possui uma relevância histórica desde as Escolas de Aprendizes Artífices, criadas, em 1909, pelo então Presidente do Brasil, Nilo Peçanha, passando pelas Escolas Técnicas, Agrotécnicas Federais, CEFET's e, atualmente no contexto dos Institutos Federais; Estes, conforme preconiza a Lei 11.892/2008 no artigo VI inciso I, "têm por finalidades e características formar e qualificar cidadãos com vistas na atuação profissional nos diversos setores da economia, com ênfase no desenvolvimento socioeconômico local, regional e nacional" (BRASIL, 2008).

No ano de 2004, houve uma reorganização da Educação profissional no Brasil, na Política Educacional do Governo do presidente Lula, através do Decreto 5.151/2004, o qual manteve a educação profissional como etapa formativa própria, porém possibilita à oferta nas diferentes formas:

I- Integrada, oferecida somente a quem já tenha concluído o ensino fundamental, sendo o curso planejado de modo a conduzir o aluno à habilitação profissional técnica de nível médio, na mesma instituição de ensino, contando com matrícula única para cada aluno;

II-Concomitante, oferecida somente a quem já tenha concluído o ensino fundamental ou estejam cursando o ensino médio, na qual a complementaridade entre a educação profissional técnica de nível médio e o ensino médio pressupõe a existência de matrículas distintas para cada curso [...];

III - Subsequente, oferecida somente a quem já tenha concluído o ensino médio (BRASIL,2004, grifos meus).

Posteriormente, houveram novas alterações instituídas através da Lei 11.741/2008 que propunha "redimensionar, institucionalizar e integrar as ações da educação profissional técnica de nível médio, da educação de jovens e adultos e da educação profissional e tecnológica” (BRASIL, 2008). Esta lei provocou modificações suprimindo e inserindo novos itens da LDB n9394/96, em destaque, a introdução da forma integrada da educação profissional com o ensino médio no capítulo que trata da Educação Básica, na Seção IV-A “Da Educação Profissional Técnica de Nível Médio", e seus quatros artigos (36-A, 36-B, 36C, 37-D) permitindo uma ampliação de possibilidade de acesso à essa modalidade de ensino configurando uma maior democratização da educação.

Por ser uma modalidade de ensino abrangente, a EPT possui diversos cursos em variados níveis, a saber:

(I) Formação inicial e continuada ou qualificação profissional;

(II) Educação profissional técnica de nível médio e

(III) Educação profissional tecnológica de graduação e pós-graduação (parágrafo $2^{\circ}$, incisos I, II e III). 
Essa descrição nos faz compreender que esta modalidade de ensino, além de sua caracterização específica voltada ao mundo do trabalho, dentro da sua objetividade, também faz parte da educação básica, conforme conteúdo descrito no caput do art. $2^{\circ}$ da LDB9.394/96, reforça este caráter da EPT de qualificação para o trabalho quando diz que a educação tem como finalidade: “... o pleno desenvolvimento do educando, seu preparo para o exercício da cidadania e sua qualificação para o trabalho” (Brasil, 1996).

Neste sentido, basicamente a concepção da educação fica explicitada no binômio exercício da cidadania-preparação para o trabalho, o que não desautoriza ou menospreza seu caráter propedêutico, mas no sentido de formação geral do educando em seus diferentes aspectos. 


\section{FORMAÇÃO E DOCÊNCIA: DESAFIOS E REALIDADES}

[...] ensinar não é transferir conhecimento, mas criar as possibilidades para a sua produção ou a sua construção (Freire, 2014, p.24).

Segundo Veiga (2008), a utilização do termo docência, como atividade profissional é algo novo nos discursos sobre a educação. Seu registro na língua Portuguesa é datado de 1916. Segundo a pesquisadora, "no sentido etimológico, docência, tem suas raízes no latim docere, que significa ensinar, instruir, mostrar, indicar, dar a entender”. E no sentido formal, "docência é o trabalho dos professores" os quais compreendem uma diversidade de trabalhos correlatos ao processo de ensinar. Do ponto de vista legal, a LDB 9394/96 estabelece no art.13 quais são esses trabalhos formais:

\footnotetext{
[...]participar da elaboração da proposta pedagógica; elaborar e cumprir plano de trabalho; zelar pela aprendizagem dos alunos; estabelecer estratégias de recuperação para os alunos de menor rendimento; ministrar os dias letivos e horas-aulas estabelecidos, além de participar integralmente dos períodos dedicados ao planejamento, a avaliação e ao desenvolvimento profissional; colaborar com as atividades de articulação da escola com as famílias e a comunidade (BRASIL,1996).
}

$\mathrm{Na}$ atual conjuntura econômica-social-política, a educação tem vivido um desafio muito grande que se trata da formação de sujeitos para conviver nesta sociedade globalizada e, não obstante, o trabalho do professor, a docência assume uma dimensão gigantesca, tamanha sua relevância no processo de construção do conhecimento frente à diversidade e adversidades encontradas no cotidiano das instituições de ensino.

Portanto, segundo Veiga (2008) “o exercício da docência envolve saberes específicos, os saberes pedagógicos e os saberes construídos nos espaços da experiência". E, logicamente, como afirma a pesquisadora:

\footnotetext{
A docência requer formação profissional para seu exercício: conhecimentos específicos para exercê-lo adequadamente ou, no mínimo, a aquisição das habilidades e dos conhecimentos vinculados à atividade docente para melhorar sua qualidade (VEIGA, 2008 p. 14).
}

A profissão docente se caracteriza por ser uma profissão difícil, complexa e, sem sombra de dúvida, uma profissão de tamanha responsabilidade e, esta responsabilização se verifica mediante sua função de estar sempre à frente de processos educativos que promovam transformações, que produzam conhecimentos, formação de valores e contribua para a 
formação da cidadania. Gatti (2011) nos ajuda compreender sobre a formação de professores na contemporaneidade:

\begin{abstract}
A formação de professores nesse contexto torna-se uma questão que merece novas considerações e outros posicionamentos: conhecimentos disciplinares sólidos, visão humana e seus destinos, consciência quanto aos processos de alienação social e busca de caminhos, lidar com as representações e as necessidades espirituais das pessoas, criação de formas de comunicação diferenciada com as crianças e jovens conhecimentos, saberes, didática, valores. (GATTI, 2011 p. 12).
\end{abstract}

Nessa perspectiva, as reflexões de Pimenta (2012, p. 15) corroboram com este estudo quando enfatizam a questão de estar repensando a formação inicial e contínua dos professores a partir da prática docente e pedagógica nos seus contextos escolares, "contrapondo a corrente de desvalorização profissional do professor e às concepções que consideram o professor como técnico reprodutor de conhecimentos e ou monitor de programas pré-elaborados". Ainda segundo a pesquisadora, "cada vez mais se torna necessário o seu trabalho enquanto mediação nos processos constitutivos da cidadania dos alunos, para o que concorre a superação do fracasso e das desigualdades escolares".

Segundo Pimenta ${ }^{1}$ as pesquisas realizadas pelos pesquisadores Pico Nez (1991), Pimenta (1994), Leite (1995):

[...]têm demonstrado que os cursos de formação inicial, tem desenvolvido um currículo formal com conteúdo e atividades de estágios distanciados da realidade das escolas, numa perspectiva burocrática e cartorial que não dá conta de captar as contradições presentes na prática social de educar, pouco têm contribuído para gestar uma nova identidade do profissional docente.[...] No que se refere à formação contínua, a prática mais frequente tem sido de realizar cursos de suplência e ou atualização dos conteúdos de ensino (PIMENTA, 2012, 16-17).

Em contrapartida, o que realmente se espera desses cursos de formação inicial e ou na forma continuada que eles colaborem na construção da identidade do professor, ou seja, colabore para o exercício da atividade docente.

Dada a natureza do trabalho docente, espera-se que os cursos de formação "desenvolva nos alunos conhecimentos e habilidades, atitudes e valores que lhes possibilitem permanentemente irem construindo seus saberes-fazeres[...]a partir das necessidades e desafios que o ensino como prática social lhes coloca no cotidiano".2

O professor se torna se não o principal, mas um dos principais responsáveis pela

\footnotetext{
1 ibid., p.16

2 ibid., p.18-19
} 
qualidade do ensino ministrado nas instituições e, diante deste mundo globalizado, de intensas transformações, as condições de trabalho, valorização e, especificamente, a formação desse profissional que vai formar outros profissionais e contribuir com o desenvolvimento socioeconômico e cultural do país, necessita ser remodelada constantemente e estar no topo das prioridades das políticas públicas de formação, bem como, principalmente, no topo dos debates e ações reflexivas das Instituições que formam esses profissionais para atuarem na área da educação.

Nesse contexto, a identidade da profissão do professor precisa ser transformada, possuir novas características para responder às novas exigências socioculturais. Para Paulo Freire (2014) existem saberes demandados pela prática educativa em si mesma, independentemente da posição política ou ideológica, da postura progressista ou conservadora do educador. A formação docente pensada por ele se refere a uma formação que leve a uma prática educativa transformadora. E, para isso, o professor deve partir de alguns saberes fundamentais. Saber-se que, ensinar exige: pesquisa; criticidade; estética e ética; rigorosidade metódica; respeito aos saberes do educando; corporificação das palavras pelo exemplo; risco, aceitação do novo e rejeição a qualquer forma de discriminação; reflexão crítica sobre a prática e o reconhecimento e a assunção da identidade cultural ${ }^{3}$.

A constituição da identidade do professor se respalda em um repertório de saberes que vão se constituindo e se reelaborando. Segundo Pimenta (2012), os saberes da docência se constituem em saberes da experiência, saberes do conhecimento e saberes pedagógicos.

Os saberes da experiência vão sendo construídos sobre o que é ser professor, seja pela experiência de quando estiveram enquanto alunos, seja por meio da experiência, socialmente acumulada, e ou por aqueles produzidos no próprio cotidiano docente mediante a reflexão da prática entre seus pares.

Os saberes do Conhecimento são os saberes específicos de uma determinada área ou subárea do conhecimento que tenha sido cursada na graduação. Fundamentalmente, o professor deve se questionar para que ensinar e qual será o significado daquele conhecimento na vida de seus alunos. No entanto, esse saber precisa ser compreendido na sua dimensão sistêmica de ser. O professor e o aluno precisam saber que o conhecimento não se reduz a informação, essa, é o primeiro estágio do conhecimento. Segundo Pimenta ${ }^{4}$,

\footnotetext{
3 Ver obra de Paulo Freire: Pedagogia da Autonomia: sabres necessários a prática educativa onde são apresentadas reflexões sobre a relação educadores-educandos.

${ }^{4}$ ibid., p.23
} 
Conhecer implica um segundo estágio: o de trabalhar com as informações classificando-as, analisando-as e contextualizando-as. O terceiro estágio tem a ver com a inteligência, a consciência ou sabedoria. Inteligência tem a ver com arte de vincular conhecimento de maneira útil e pertinente, isto é, de produzir novas formas de progresso e desenvolvimento; consciência e sabedoria envolve reflexão, isto é, capacidade de produzir novas formas de existência, de humanização.

Os saberes pedagógicos não se restringem somente aos saberes didáticos, onde se pressupõe que a didática ofereça técnicas a serem aplicadas em toda e qualquer situação para que o ensino dê certo. Os saberes pedagógicos são construídos a partir das necessidades pedagógicas e articulados com os saberes da experiência e saberes científicos ou do conhecimento.

Corroborando com esta reflexão, Rios (2010) complementa, quando diz que a práxis docente considerada da melhor qualidade é aquela que se confirma a existência das dimensões técnicas, estética, política e ética e que haja um relacionamento recíproco entre elas. Nesse sentido, não basta dominar os conteúdos da área de formação e ou atuação, se faz necessário pensar criticamente no valor efetivo desses conceitos, exercer a criatividade para o bem-estar coletivo, ter comprometimento político na ação docente no sentido de colaborar com uma vida mais digna e solidária.

Abrindo um parêntese e fazendo uma retrospectiva na história da educação, vimos que as práticas pedagógicas desenvolvidas no contexto da escola tradicional basicamente se davam na imposição da disciplina, as aulas aconteciam de forma descontextualizada, os procedimentos e instrumentos pedagógicos eram limitados. Predominava o métodopedagógico expositivo, onde os alunos, sentados em carteiras enfileiradas, se prestavam a ouvir atentamente as exposições e ou explicações do professor, limitando, assim, a possibilidade de interação e troca de informações pelos presentes em sala de aula.

A escola tradicional atendia aos preceitos da burguesia de manter os indivíduos com sua autonomia isolada e estéril.

[...] o insucesso da escola tradicional decorreria de seu modo de funcionar, pois ela está organizada com base em conteúdos livrescos, exames e provas reprovações e relações autoritárias. Busca-se, então, outro tipo de escola, abrindo espaços e tempos que venham atender às necessidades básicas de aprendizagem [...] tomadas como eixo do desenvolvimento humano. (LIBÂNEO, 2012, P.17)

Nos tempos remotos, reinava a obediência extrema e a passividade dos alunos, embora saiba que, pedagogicamente, a função do professor consiste em criar condições e possibilidades para que o aluno aprenda. $\mathrm{E}$ aos alunos cabe a percepção de sua participação na 
construção do seu próprio saber.

Essa retrospecção mesmo que limitada ao tempo, nos faz pensar sobre o motivo que levaram tantos pesquisadores como Lev Vygotsky (1896-1934), Henri Wallon (1879-1962), Jean Piaget (1896-1980), Paulo Freire (1921-1997) e David Ausubel (1918-2008) a pesquisarem sobre novas concepções de ensino, apontando os caminhos que levam os alunos a aprenderem e sobre o papel dos educadores como mediadores do conhecimento. E como dizia Paulo Freire (2014, p.40) "É pensando criticamente a prática de hoje ou de ontem que se pode melhorar a próxima prática".

A concepção do processo ensino-aprendizagem, na visão desses autores, deu lugar a propostas de novas teorias psicopedagógicas, as quais, de maior destaque nos dias atuais, são as de abordagem construtivista e sócio interacionista, na qual o professor identifica a forma como o aluno adquire conhecimento e o mesmo vai se modificando suas estruturas cognitivas através da construção desse conhecimento, ou seja, o processo de aquisição e construção do conhecimento pelo aluno passa a fazer parte do processo dialético do ofício do professor.

\begin{abstract}
A invasão do construtivismo em nossa sociedade é uma realidade da qual não podemos fugir. A escola tradicional - que sofreu inúmeras transformações ao longo de sua existência e que, paradoxalmente, continua resistindo ao tempo -, dia-a-dia, vem sendo questionada sobre sua adequação aos padrões de ensino exigidos pela atualidade, mas ao mesmo tempo é retentora da grande maioria das escolas do nosso país (LEÃO,1999, p. 188).
\end{abstract}

Rubem Alves (1933 - 2014) falando sobre a escola ideal e o papel do professor nos diz que "[...] a transformação da educação no Brasil ela passa por dentro dos pensamentos e dos sentimentos dos professores. O professor é o ponto central de qualquer programa de transformação do ensino brasileiro".

A pedagogia contemporânea tem o entendimento de que o professor não é o único detentor do conhecimento. Àquela pedagogia centrada no professor e não no aluno são práticas pedagógicas que se caracterizam cada vez mais como obsoletas, tradicionais e, não colabora para a produção do conhecimento de forma significativa. Evidencia-se que, a pedagogia deve estar centrada no processo ensino-aprendizagem, que o ensinar e o aprender aconteça através de processos interativos de reflexão, no qual teremos professor que deseja ensinar e aluno que deseja aprender.

Tardif e Lessard (2011), quando discutem sobre a escola como organização do trabalho docente, nos ajuda a compreender melhor este processo de mudança afirmando que:

[...] a ação pedagógica não pode nunca se limitar a coerção e ao controle autoritário, porque ela exige, para ter êxito uma certa participação dos alunos e, de algum modo, seu "consentimento" [...] sua "motivação". [...]. Ninguém pode forçar alguém a 
aprender (embora se possa forçá-lo a fazer de conta que aprende ou submetê-los ao símbolo exteriores da aprendizagem). Mesmo aí, parece que estaríamos lidando com os traços constitutivos da ação pedagógica em ambiente escolar: a escola e a classe são ambientes abertos, no seio dos quais os docentes nunca controlam totalmente seu objeto de trabalho. Ensinar é lidar com um "objeto humano", um ser humano sempre, ao menos em parte, subtraído a ação do trabalhador. [...] o trabalhador precisa contar com uma certa participação do seu "objeto" para atingir seus objetivos. Essa participação dos alunos das "estratégias de motivação" que empenham uma boa parte do ensino (TARDIF \& LESSARD, 2011, p. 67).

Para esses autores, o trabalho docente tem em sua prática os elementos para as interações dos variados sujeitos no contexto escolar, ou seja, à docência como profissão de interações humanas que suscita em processos reflexivos, investigativos rumo à produção de conhecimentos. "O que mobiliza um aluno, o que o introduz em uma aprendizagem, o que lhe permite assumir as dificuldades da mesma [...] é o desejo de saber e a vontade de conhecer" (MEIRIEU,1998, p. 86).

Freire (2014) também se refere à dimensão estética do processo ensino aprendizagem que deve ser movido por um desejo, vivido com alegria, sem abrir mão do rigor, da ética, seriedade e da simplicidade em relação ao saber da competência e complementa:

[...] ]ensinar não é transferir conhecimentos, conteúdos, nem formar é ação pela qual um sujeito dá forma, estilo ou alma a um corpo indeciso, acomodado. Não há docência sem discência, as duas se explicam e seus sujeitos, apesar das diferenças que os conotam, não se reduzem à condição de objeto um do outro. Quem ensina aprende ao ensinar e quem aprende ensinar ao aprender (FREIRE, 2014, p. 25).

\subsection{Trajetória histórica de formação docente para a EPT}

Historicamente, a origem da Educação profissional foi marcada por uma dualidade estrutural: escola acadêmica para os privilegiados e escola profissionalizante para as classes populares. Esta distinção resultou por algum tempo, em oposições marcantes na estrutura social e da formação dos cidadãos, onde uns eram preparados para o trabalho manual e outros para o trabalho intelectual.

Constatamos, através desta concepção de dualidade, que esse caráter foi se constituindo conotações de perfis diferenciados para o professor de cursos profissionalizante, como apontado no excerto a seguir:

[...] uma névoa que denotava a falta de perfis esperados para a Educação Profissional. Em princípio, na escola profissionalizante, bastava ao professor saber fazer o "ofício" a ser ensinado. $\mathrm{Na}$ prática, as qualidades pedagógicas eram 
secundárias em face dos conteúdos, havendo muito maior improvisação na escola profissional que na acadêmica. (CARNIELLI, GOMES e CAPANEMA, apud PONTES, 2008, p 12).

Peterossi (1994), ao falar da trajetória da formação do professor do ensino técnico, faz a seguinte constatação que serve de reflexão também para atualidade, "[...] muito mais do que uma história de sua formação encontra-se uma trajetória de não formação no sentido de que, a rigor, nunca houve uma proposta realmente consistente em relação a esses professores".

Desde o início do século XX, a educação profissional, nos moldes oferecidos pelas Escolas de Aprendizes e Artífices (1909), de caráter assistencialista, tinha, em sua origem, a intenção de oferecer alternativas para os "desvalidos da sorte", a adquirirem habilidades para o trabalho e, com isso, se ocuparem para fugir da ociosidade, do crime, das drogas, ou seja, a eles era destinado um ensino eminentemente prático e, seus professores, não tinham habilitação acadêmica, eram na sua grande maioria, operários recrutados diretamente das fábricas e oficinas. Outrora, bastava "saber fazer" para assumir a função de mestre, como eram chamados os professores da Educação Profissional.

Percebe-se, então, que a esses mestres professores, como eram chamados, faltava conhecimentos de base teórica, técnica e formação pedagógica e, na falta de uma regulamentação do trabalho pedagógico que desenvolviam, predominava nesses estabelecimentos o método imitativo de ensino (PETEROSSI, 1994, p. 32).

Todavia, essa realidade de carência de professores de ensino técnico habilitados em nível superior, e excepcionalmente em atendimento à exigência da Lei $\mathrm{n}^{\circ} 5.540 / 68$, levou o MEC, segundo Machado (2008), a ser autorizado, em 1969, a organizar e coordenar cursos superiores de formação de professores para o ensino técnico agrícola, comercial e industrial. Logo, em atendimento a esse pleito foi então criado através do decreto Lei 616/1969, O Cenafor - Centro Nacional de Aperfeiçoamento de Pessoal para a Formação Profissional, o qual tinha como finalidade:

A preparação e o aperfeiçoamento de docentes, técnicos e especialistas em formação profissional bem como a prestação de assistência técnica para a melhoria e a expansão dos órgãos de formação e aperfeiçoamento de pessoal existente no País. (BRASIL, 1969)

Entretanto, através da Portaria 432/71, a formação de professores para atender as "disciplinas específicas de $2^{\circ}$ grau" se configurou por cursos especiais, identificados por emergenciais, denominados de: Esquema I e Esquema II. Sendo que o curso de Esquema I, de complementação pedagógica, com carga horária de 600 horas, destinava - se a candidatos 
com graduação em nível superior relacionado à habilitação pretendida e era composto pelas disciplinas: Estrutura e Funcionamento do Ensino de $2^{\circ}$ grau, Psicologia da Educação, Didática e Prática de Ensino, esta última com 290 horas.

O curso de Esquema II, para candidatos habilitados em curso técnico de nível médio e equivaliam à licenciatura de nível superior por que habilitava os portadores de diplomas de técnico de nível médio ao magistério de $2^{\circ}$ Grau. Esses cursos abrangiam conteúdos propedêuticos, pedagógicos e da área técnica, e tinham como objetivo, suprir a carência de pessoal docente de nível superior em diversas regiões do país.

No plano legal, se percebe que havia uma preocupação, mas se tratava de instrumentalizar o professor para melhor exercer sua profissão, conforme descreve Raul Albino Pacheco Filho, ao se referir aos cursos do Esquema II:

[...] Equipes de professores universitários das disciplinas propedêuticas (Matemática, Química e Biologia) e das disciplinas específicas (Agricultura, Zootecnia e Economia e Administração Rural) foram coordenadas por psicólogos especializados em análise comportamental e em ensino individualizado, para elaborarem o material instrucional (textos de leitura, instruções, exercícios e avaliações) das diferentes disciplinas que compunham os referidos cursos. Dois cursos distintos foram elaborados: um para professores das disciplinas especializadas relacionadas à Agricultura e outro para professores das disciplinas específicas relacionadas à Zootecnia (FILHO, 1998, p. 3, grifos meus).

A partir da segunda LDB de $n^{\circ} 5.692 / 71$, se percebe a exigência da formação em nível superior para os professores das "disciplinas do $2^{\circ}$ grau". Diante dessas novas regulamentações houve a criação de cursos de graduação plena para a formação de professores das disciplinas específicas.

Assim, a Resolução n ${ }^{\circ}$ 03/77 possibilitou a oferta de cursos de licenciatura na área de Técnicas Agropecuárias, Técnicas Industriais, Técnicas Comerciais e de Serviços e Técnicas de Nutrição e Dietética. Os cursos de Esquema foram convertidos em Licenciatura, admitindo-se, entretanto, a continuidade dos primeiros em caráter emergencial em regiões com insuficiência de recursos humanos.

Contudo, apesar das novas leis e regulamentações, a formação do professor para o ensino técnico continuou tendo um caráter emergencial, onde cursos eram oferecidos em formas de programas e, desta forma, impedindo a constituição de saberes sistematizado da área, conforme destacado por Oliveira (2005):

[...] algo especial, emergencial, sem integralidade própria, que carece de marco regulatório e, por meio de programas, desenvolve-se, paradoxalmente, sem a superação das situações vigentes e ditas emergenciais, e sinalizando uma política de 
falta de formação. Aliás, essa falta de formação justifica-se pelo recorrente nãoreconhecimento de um saber sistematizado próprio da área (OLIVEIRA, 2005, p. 9).

Posteriormente, no ano de 1986, houve a extinção do CENAFOR e da Coordenação Nacional do Ensino Agrícola/COAGRI, sendo transferida sua responsabilidade de promover ações de formação de professores do ensino técnico para a Secretaria de Segundo Grau (SESG) do MEC. Assim, a formação de professores passou a ser realizada pelos primeiros CEFETs - Centros Federais de Educação tecnológica, em especial o do Estado de Minas Gerais e do Paraná que carregava uma tradição na oferta desses cursos.

Desta forma, ficou evidenciado que a integração da formação técnica contida no nível médio foi o divisor de águas no entendimento de que deveria ter uma exigência de uma formação mais sólida para os professores deste nível de ensino com a construção de um perfil específico para a área técnica com desdobramentos na natureza do trabalho pedagógico.

No cenário contemporâneo, com a promulgação da LDB 9.394/96 e mais precisamente a partir do Decreto 2.208/97, houve novas proposições sobre a formação de professores da Educação profissional - o qual previa que as disciplinas técnicas poderiam ser ministradas por professores, instrutores e monitores, selecionados em função de sua experiência profissional, tais professores deveriam ser preparados para o magistério, previamente ou em serviço, através de cursos regulares de licenciatura ou de programas especiais de formação pedagógica.

Nestes termos, a Portaria 646/97, que regulamentou o decreto citado anteriormente, definiu que caberia às Instituições Federais de Educação Tecnológica, quando autorizadas, desenvolver esses programas especiais.

Já o Decreto $n^{\circ}$ 2.406/97, que regulamentou a Lei $n^{\circ} 8.948 / 1994$, repassou para os Centros de Educação Tecnológica, concebidos como instituições especializadas de Educação Profissional, a poder ministrar não apenas programas especiais de formação pedagógica para as disciplinas de educação científica e tecnológica, mas também cursos de formação de professores e especialistas.

A Resolução $n^{\circ}$ 02/97 que dispõe sobre os programas, em caráter especial, de formação pedagógica de docentes para suprir a falta nas escolas de professores habilitados para o currículo do ensino fundamental, do ensino médio e da educação profissional em nível médio em determinadas disciplinas e localidades, estabeleceu em seu art. $3^{\circ}$ uma estruturação curricular articulada da seguinte forma: 
a) Núcleo Contextual, visando à compreensão do processo de ensino-aprendizagem referido à prática da escola, considerando tanto as relações que se passam no seu interior, com seus participantes, quanto as suas relações, como instituição, com o contexto imediato e o contexto geral onde está inserida.

b) Núcleo Estrutural, abordando conteúdos curriculares, sua organização sequencial, avaliação e integração com outras disciplinas, os métodos adequados ao desenvolvimento do conhecimento em pauta, bem como sua adequação ao processo de ensino-aprendizagem.

c) Núcleo Integrador, centrado nos problemas concretos enfrentados pelos alunos na prática de ensino, com vistas ao planejamento e reorganização do trabalho escolar, discutidos a partir de diferentes perspectivas teóricas, por meio de projetos multidisciplinares, com a participação articulada dos professores das várias disciplinas do curso. (BRASIL, 1997, grifos meus)

Convém também destacar, que no parecer no 37/2002 emitido pelo Conselho Nacional de Educação-CNE/Câmara de Educação Básica sobre a consulta formulada a respeito da formação e do exercício das atividades de docentes para a Educação Profissional de Nível Técnico, o conselheiro Ataíde Alves, fundamenta seu relatório com base em dispositivos legais, a saber:

[...] A rigor, à docência para a educação profissional não está completamente regulamentada. Os dispositivos legais e normativos em vigor constituem respaldo suficiente para um entendimento relativamente flexível e adequado às múltiplas e cambiantes necessidades da educação profissional. A LDB oferece a base legal ampla e mínima. As normas sobre licenciatura, inclusive sobre programas especiais de formação pedagógica, que, em linhas gerais destinam-se à educação básica, permitem adequações pertinentes à educação profissional. A propósito, cumpre lembrar que a Resolução CNE/CP 02/97, embora inclua a docência para a educação profissional de nível médio (a ser entendido como técnico) e de forma indireta, no artigo $9^{\circ}$, revogue a Portaria MEC 432/71 que regula os antigos Esquemas I e II, não leva em conta as necessidades específicas dessa modalidade educativa. Curiosamente, o Decreto 2.208/97, anterior a essa Resolução, dispondo também de forma genérica sobre a docência no ensino técnico (artigo $9^{\circ}$ ), já fazia referência expressa a "programas especiais de formação pedagógica" são os ajustes de percurso que a realidade nacional acabou impondo aos trabalhos do CNE. A portaria $n^{\circ} 432 / 71$ e o Decreto 2.208/97 foram pretexto e inspiração para uma Resolução destinada a oferecer, primordialmente, alternativa para a formação de professores para a educação básica. (BRASIL, 2002, grifos meus).

Portanto, nem na LDB nº 9.394/96, legislação educacional vigente, não há, de forma clara e direta, a exigência de requisitos legais para atuar como professor de EPT. Esta lei apenas deixa bem clara as diretrizes para a formação de docentes para atuar na educação básica e na educação superior. Porém, em relação a modalidade de Educação Profissional, constata-se que no Decreto $n^{\circ} 2.208 / 97$, a permissão para que professores da EPT pudessem ser inclusive instrutores, o que evidencia a caracterização desta tradição legal, da não exigência de formação docente para essa modalidade de ensino. 
Em contrapartida, a EPT também tem a Educação Básica em seu bojo de atendimento, atende alunos da Educação Básica ao Ensino Superior. Portanto, o entendimento que se faz é de que essa modalidade de ensino deveria orientar-se pela legislação preconizada para esses dois níveis de ensino em relação à contratação de seus professores.

Por outro lado, o processo formativo amplo e por muitas vezes complexo exige uma responsabilidade enorme sobre a figura do professor a quem cabe se munir de constructos científicos e de metodologias didático-pedagógicas para proporcionar uma aprendizagem significativa aos seus alunos, formando profissionais com competências e habilidades para o exercício de uma profissão e conjuntamente para o exercício pleno da cidadania.

Dentro das características e finalidades para quais foram criados os Institutos Federais, Lei nº 11.892/2008, se faz pertinente analisar as políticas de Formação do professor, principal responsável, na prática, para que esta expansão se estabeleça e se firme em condições concretas de funcionamento com qualidade

Nesse contexto, vale ressaltar que tem possibilidade de estar avançando nas discussões e proposições de formação para os profissionais da educação, pois no Plano Nacional de Educação - PNE 2014-2024, sancionado pela Presidente Dilma Rousseff no dia 25 de junho de 2014 através da Lei 13.005/2014, estabelece na meta de $n^{\circ} 15$ políticas de formação para os profissionais da educação, o qual versa em seu caput “... Garantir em regime de colaboração entre União, Estados, Distrito Federal e os Municípios, no prazo de I(um) ano da vigência deste, política de formação dos profissionais da educação”.

Para compreensão de quem seja esses profissionais da educação ressalta-se a nova redação dada através da Lei $n^{\circ} 12.014$, de 2009, conforme estabelecido nos incisos I.II. III do caput do artigo 61 da LDB 9.394/96,

I - professores habilitados em nível médio ou superior para a docência na educação infantil e nos ensinos fundamental e médio;

II - trabalhadores em educação portadores de diploma de pedagogia, com habilitação em administração, planejamento, supervisão, inspeção e orientação educacional, bem como com títulos de mestrado ou doutorado nas mesmas áreas;

III - trabalhadores em educação, portadores de diploma de curso técnico ou superior em área pedagógica ou afim. (Brasil, 2009, grifo meus).

Observamos, pela conjuntura da EPT, que se fez necessário incluir nesta lista como profissionais da educação, os trabalhadores do ensino técnico e tecnológico com a formação mínima exigida, ou seja, o curso a nível de bacharelado na área específica e ou eixo tecnológico de atuação do professor. 
A despeito da análise e reflexão para este estudo, eis o destaque a duas metas estabelecidas no PNE 2014-2024 que retratam sobre a formação para atuar como docente:

15.9) implementar cursos e programas especiais para assegurar formação específica na educação superior, nas respectivas áreas de atuação, aos docentes, com formação de nível médio na modalidade normal, não licenciados ou licenciados em área diversa da de atuação docente, em efetivo exercício.

15.13) desenvolver modelos de formação docente para a educação profissional que valorizem a experiência prática, por meio da oferta, nas redes federal e estaduais de educação profissional, de cursos voltados à complementação e certificação didáticopedagógica de profissionais experientes. (Brasil, 2014)

Por outro lado, no entanto, se observa que, diante do que está previsto no PNE 20142024, recém sancionado, nos termos da Lei 13.005/2014, a formação do professor, em exercício, da Educação Profissional, que não possui formação específica na área de atuação poderá ser oferecida em cursos e programas especiais e, neste caso, a implementação da formação continuada fica a cargo da gestão das Instituições que ofertam EPT.

Pelo exposto, evidencia-se que, em termos legais, ainda não foi consolidado uma política de formação inicial para àqueles futuros docentes da EPT que ainda não ingressaram nesta área de atuação. Embora, evidencia-se ser um campo que requer amplas discussões sobre o perfil requerido ao professor de EPT.

Ultimamente, têm surgido diferenciadas propostas. Machado (2008), em umas de suas discussões, enfatiza que o docente da EPT deve dar conta de três níveis de complexidade:

a) desenvolver capacidades de usar, nível mais elementar relacionado à aplicação dos conhecimentos e ao emprego de habilidades instrumentais;

b) desenvolver capacidades de produzir, que requer o uso de conhecimentos e habilidades necessários à concepção e execução de objetivos para os quais as soluções tecnológicas existem e devem ser adaptadas; c) desenvolver capacidades de inovar, nível mais elevado de complexidade relacionado às exigências do processo de geração de novos conhecimentos e novas soluções tecnológicas (MACHADO, 2008, p.15-16).

Diante deste cenário de expansão da Rede Federal com a criação dos Institutos Federais de Educação, Ciência e Tecnologia, evidencia ainda mais a necessidade de políticas públicas de formação para o docente da EPT, uma vez que a demanda de professores para atuarem nesta modalidade, se amplia e, não se observa nos dias de hoje, a exigência de uma formação ampliada e específica desse profissional para atender a demanda de cidadão que busca uma formação profissional. A despeito disso, nos dizeres de Costa, o MEC, pelo contrário: 
[...] por meio da SETEC, se propôs a regulamentar o acesso de professores, inclusive de nível médio, para atuar em programas, também reducionistas, de capacitação profissional, como é o caso do PRONATEC. Essas regulamentações emergenciais, explicitam status desprivilegiado em que se concebe a profissão docente na EPT [...]. (COSTA, 2012, p. 3).

Neste sentido, as Diretrizes Curriculares Nacionais-DCNs para Educação Profissional Técnica de Nível Médio, normatizadas pela Resolução no 6/2012, em seu título IV no caput do Art. 40, que trata da Formação Docente estabelece que:

\begin{abstract}
A formação inicial para a docência na Educação Profissional Técnica de Nível Médio realiza-se em cursos de graduação e programas de licenciatura ou outras formas, em consonância com a legislação e com normas específicas definidas pelo Conselho Nacional de Educação (BRASIL. 2012, grifo meus).
\end{abstract}

Daí decorre que, na própria Lei que estabelece as DCNs para esta modalidade de ensino, permite "outras formas" de formação inicial do professor que não seja curso de graduação e ou licenciatura. E o $\S 2^{\circ}$ do referido art. 40, introduz a estratégia de certificação profissional para a docência na EPT, as quais evidencia uma série de apontamentos e controvérsias muito bem ressaltadas por Pontes:

\begin{abstract}
A opção pela certificação poderá esvaziar iniciativas de formação de professores da EPT, atraindo-os com o objetivo imediatista de buscar apenas a sua certificação; A certificação se mostra, de saída, comprometida em sua qualidade, dada a ausência de marcos regulativos claros pela inexistência de Diretrizes Curriculares para a formação dos professores da EPT; Há o risco de pouco ou deficiente acompanhamento e monitoramento das iniciativas de certificação dada à natureza e complexidade de tal processo. - Tal iniciativa poderá prejudicar a consolidação de uma política de formação para os docentes da EPT para além de um caráter emergencial e fragmentado. A proposta de certificação vai de encontro a uma formação alinhada a uma educação profissional que assume como perspectiva a formação integral do estudante, como a proposta de Ensino Médio Integrado à Educação Profissional. (PONTES, 2014, p.96.)
\end{abstract}

Todas essas evidências e apontamentos de regulamentações emergenciais, advindo das "outras formas" de formação inicial, em que se observa a possibilidade da opção de certificação para esses professores, evidencia-se a compreensão do caráter da não priorização da formação docente para EPT e consequentemente ocasionando uma desvalorização da profissão.

Em contrapartida, depreende-se de todos estes aspectos de formação historicamente apresentados, sem dúvida que, a constatação que se faz não se refere apenas ao aspecto de exigência legal, mas a clara e evidente necessidade de investir em políticas públicas de 
formação para o docente de EPT, com vistas a redimensionar o processo ensinoaprendizagem, frente ao contexto atual nesta sociedade, marcada por intensas transformações.

Neste contexto, se tornam inegável e urgente que esta discussão sobre a formação do docente para EPT precisa estar no centro dos debates, não somente na esfera governamental, mas principalmente no meio acadêmico, conforme mencionado por Carvalho e Souza (2014), quando defendem a necessidade das faculdades de educação e dos cursos de pedagogia dialogarem sobre a formação do docente da EPT no Brasil, eis a constatação desses autores:

\begin{abstract}
A preocupação com a EPT está, portanto, ausente da formação do pedagogo propriamente dita, visto que tem seu foco no magistério da educação infantil e das séries iniciais do ensino fundamental. Esta ausência de preocupação com a EPT também está presente no âmbito das licenciaturas nos diversos campos do conhecimento científico e, seguramente, não faz parte do repertório epistemológico das faculdades de educação brasileiras. (CARVALHO \& SOUZA, 2014, p. 892).
\end{abstract}

Observa-se que as faculdades de educação têm muito a contribuir se agregassem em seus currículos das graduações e ou licenciaturas a questão da formação docente para atuação na EPT.

Nesse âmbito específico, os currículos, segundo Carvalho e Souza (2014), "poderia fazer-lhes compreender o processo educativo de maneira ampla [...]. Esses estudos seriam realizados nos núcleos especializados que abrangem vários domínios epistemológicos, relacionados à atividade educativa".

Não obstante, considerando a necessidade de uma formação ampliada do cidadão moderno e também a complexidade das atribuições designadas aos Institutos Federais, percebe-se a necessidade de um perfil diferenciado para esses professores, na perspectiva da formação geral/acadêmica na área específica em que vão atuar; experiência laboral e, evidentemente, uma formação pedagógica complementar e humanística que os capacite para melhor exercer a docência, uma vez que, a maioria deles, em especial os bacharelados, além do curso não ter tido esse enfoque voltado para a docência, os mesmos não pretendiam exercer a profissão de professor quando realizou a sua formação inicial. Para compreensão da finalidade do curso de bacharelado, Menezes (2002) define o curso como sendo um:

Curso de nível superior de graduação que o estudante realiza para obter formação profissional em uma área específica, além de conquistar o título de Bacharel. Esse título possibilita a continuidade dos estudos através de uma pós-graduação. $\mathrm{O}$ bacharelado, no entanto, não permite o exercício do magistério. Somente o curso de licenciatura, realizado de forma paralela ou após o bacharelado, permite ensinar em escolas de nível fundamental ou de nível médio (MENEZES, 2002, p. 18) 
Disso, se torna evidente que o Bacharelado é uma graduação que prepara o profissional para atuar numa determinada área específica e seu enfoque acadêmico é altamente científico, voltado para a pesquisa. Ao passo que, o curso de Licenciatura nas Universidades e Faculdades de Educação, em tese, deve possuir um enfoque voltado mais para as questões pedagógicas, onde a sua formação é para ser professor de determinada área do conhecimento, conforme definição de Licenciatura feita pela mesma pesquisadora (ibid),

\begin{abstract}
Curso que tem por objetivo formar professores para o ensino nos níveis fundamentais e médio [...] elas nasceram seguindo a fórmula em que as disciplinas de natureza pedagógica [...] estavam justapostas às disciplinas de conteúdo [...]. Um decreto complementar à LDB estabelece que as licenciaturas devem ter uma base comum e um currículo norteado por competências e fundamentado na associação entre teoria e prática. As faculdades precisariam, para isso, criar vínculos com os sistemas de ensino, participando do dia-a-dia das escolas e usando-as como objeto de estudo. (MENEZES, 2002, p. 24)
\end{abstract}

Ademais, no contexto dos Institutos Federais, a realidade revelada até então é a de que a maioria desses professores assumem a docência, sem ter passado por uma formação específica para ser professor. Logo, sua formação é predominantemente técnico-científica, de caráter eminentemente acadêmica e, na sua grande maioria, chegam aos Institutos com formação em nível de bacharelado, tecnólogos, outros com formação stricto sensu: os mestrados e ou doutorados que, em uma expressiva maioria, são na área técnica e científica, ou seja, também não tem esta finalidade de preparar professores.

Por outro lado, sabe-se que a formação docente não acontece da noite para o dia. Essa formação vai sendo constituída na própria experiência como professor, a qual se amplia e se caracteriza como processo formativo que, mediante a vivência na prática cotidiana de sala de aula, vão se materializando, se ajustando, se aperfeiçoando no aprender a ser professor.

Vale ressaltar que, essa experiência precisa ser sustentada, modificada através de momentos de reflexão assim como dizia Rui Canário apud Pacheco (2010) [...] "aprender a aprender com a experiência só é possível a partir da crítica e da ruptura com essa experiência, mas não parece ser essa a regra. Não aprendemos com a experiência e mantemos práticas absurdas". Ou seja, trocando em miúdos, a boa formação do professor, também se complementa com formação continuada e na própria atuação, o qual promoverá atitudes críticas e reflexivas, redirecionando a sua prática em sala de aula com vistas a promoção de um aprendizado significativo aos seus alunos.

No âmbito da formação docente, Kuenzer (1999) afirma que a articulação entre conhecimento científico e conhecimento tácito, ou seja, o conhecimento pedagógico e o da área de conteúdo, articulados entre si e articulados também com a experiência laboral 
(experiência docente e no exercício profissional na área que se ensina), fazem a diferença no processo didático na Educação Profissional.

Partindo dessas perspectivas, se faz urgente pensar em políticas públicas de formação docente para que as universidades, faculdades de educação contemple em suas graduações a possibilidade de atuação nesta modalidade de ensino, bem como as próprias instituições que ofertam EPT proporcionarem capacitações e reflexões pedagógicas constantes aos que já atuam nesses contextos e clamam por intervenções para melhorar o seu fazer pedagógico.

\subsection{Perfil docente e atuação na EPT: novos pressupostos}

O profissional docente assume importância crucial neste processo de formação cidadã. Para isso, há de se exigir um perfil diferenciado desse profissional, 'o docente da Educação Profissional e Tecnológica', ao qual se exige competências múltiplas para o seu "fazer pedagógico", capacidades de compreender o processo ensino-aprendizagem como forma de assegurar uma qualificação profissional técnica, mas, sobretudo, assegurar que sejam autônomos, reflexivos, críticos, sintonizados com as constantes mudanças ocorridas na sociedade e no mundo do trabalho.

Entretanto, como já fora abordado, a realidade dos Institutos Federais nos demonstra que a maioria desses professores assume a docência sem ter passado por uma formação específica para ser professor, ou seja, sua formação é predominantemente técnico-científica, de caráter eminentemente acadêmico.

Diante disso, as evidências podem sinalizar que, pelo fato de terem apenas a formação inicial no nível de bacharelado, os professores encontrem dificuldade em gerir a sala de aula, ou seja, em dominar estratégias diferenciadas de ensino que levam a situações de aprendizagens que efetivamente promovam as competências e habilidades do profissional técnico que a instituição pretende formar. Evidentemente, que esta dificuldade de gestão da sala de aula pode ser encontrada também por parte do licenciado que, em tese, obteve formação para assumir a docência, mas não com as especificidades da EPT, provavelmente encontrará dificuldades em conduzir o processo de ensino-aprendizagem nesta área técnica.

Porém, quando se fala em docência envolve mais dois elementos essenciais implícitos no processo educativo que são os alunos e o próprio conhecimento. Na atual conjuntura, o papel do professor se torna o de mediador do conhecimento, a sala de aula se torna um laboratório vivo de aprendizagens que vão acontecendo na medida em que o 
professor estabelece uma relação mais próxima com seus alunos e através de um conjunto de ações preferencialmente, pensadas, vai-se favorecendo a descoberta, a experimentação, comprovação, isto é, a troca de experiência entre professor-aluno-conhecimento e o mundo, contribuindo para o efetivo sucesso do processo ensino-aprendizagem. Lopes (1991), fala do planejamento de ensino numa perspectiva crítica de educação nos diz que:

[...] essa relação, inclusive, mostra-se como condição necessária para que, ao mesmo tempo em que ocorra a transmissão de conhecimentos, proceda-se a sua reelaboração com vistas à produção de novos conhecimentos. O resultado dessa relação dialética será a busca da aplicação dos conhecimentos aprendidos sobre a realidade no sentido de transformá-la [...] (LOPES, 1991 p. 24).

Portanto, nos faz pensar que o fazer pedagógico deve levar em consideração o contexto de vida dos alunos e da realidade que os cercam, dando sentido e significado àquilo que está sendo ensinado.

O professor, em sua prática pedagógica, precisa realizar a transposição didática que significa transformar o conhecimento científico obtido em sua graduação, modificando-o, de forma a torná-lo 'ensinável', dito de outra forma, o professor cria condições didáticas para que o aluno aprenda. Segundo Chevallard:

[...] a transposição didática é um processo pedagógico complexo, que implica na transformação do saber erudito ou científico em um saber possível de ser ensinado. Consiste em o professor fazer uma modificação cumulativa do saber acadêmico para que este possa ser compreendido pelo aluno. No entanto, sem reducionismo ou modificação de conceitos (CHEVALLARD, 1991, p. 32)

Assim, dominar os conteúdos da disciplina é importantíssimo, mas não se torna o único saber é preciso também dominar os saberes da ação pedagógica, a condução de sua disciplina, adequando o conteúdo às reais possibilidades cognitivas que irão influenciar diretamente na aprendizagem dos alunos. Em suma, necessário romper com o paradigma de que para ensinar basta saber, como se o domínio do conhecimento e a transposição didática desse mesmo conhecimento fossem aspectos similares e não exigissem diferentes abordagens.

Tardif (2000), se referindo aos saberes docentes, considera que:

[...]os professores de profissão possuem saberes específicos que são mobilizados, utilizados e produzidos no âmbito de suas tarefas cotidianas. São saberes que servem de base ao oficio de professor, são conhecimentos, saber-fazer, competências e habilidades que os professores mobilizam para realizar diversas tarefas, em sala de aula ou na escola (TARDIF, 2000, p.113). 
Nesta perspectiva, corrobora com o pensamento de Vasconcellos (2002) quando fala da questão da gestão da sala de aula, a qual precisa estar pautada em três princípios básicos: "que de fato o aluno aprenda, se desenvolva e seja feliz". Assim, o aluno se sente feliz, motivado e empolgado quando se vê, com condições de superar suas dificuldades e estar construindo seu conhecimento. Para isso, Vasconcellos (ibid) corrobora dizendo que:

\footnotetext{
A Educação Escolar é um processo coletivo, sistemático e intencional de interação com a realidade, através do relacionamento humano baseado no trabalho com o conhecimento e na organização da coletividade, cuja finalidade é colaborar na formação do educando na sua totalidade — consciência, caráter, cidadania-, tendo como mediação fundamental os saberes que possibilitam a emancipação humana (VASCONCELLOS, 2002, P.21).
}

Segundo Vasconcellos (ibid.), a gestão da sala de aula, compreende basicamente três grandes dimensões: A primeira é o relacionamento interpessoal que tem a ver com essa capacidade do professor se aproximar mais intimamente, com maior cuidado e profundidade, diante de uma dificuldade do aluno, seja em termos de aprendizagem ou de disciplina, isto é, a capacidade de uma relação mais próxima, olho no olho. A segunda é a organização da coletividade - diz respeito àquilo que costumamos chamar de disciplina. $\mathrm{E}$ a terceira é o trabalho com o conhecimento - envolve três aspectos básicos: mobilização para o Conhecimento (para conhecer o sujeito precisa querer); construção do conhecimento propriamente (o conhecimento envolve atividade, seja motora, perceptiva e/ou reflexiva, para poder se apropriar do objeto de conhecimento); elaboração e expressão da síntese do conhecimento (para que se feche o ciclo do conhecimento é essencial que, de alguma forma, o sujeito se expresse a respeito dele).

Ademais, o ofício de mediar o conhecimento exige uma entrega por parte dos professores que lidam diretamente com seres humanos em formação com a finalidade de superar o aspecto de repetidor de conteúdo para despertá-lo para o pensamento crítico e reflexivo, conforme salientado por Coelho:

O ofício de ensinar não é para aventureiros, é para profissionais, homens e mulheres que, além dos conhecimentos da área dos conteúdos específicos e da educação, assumem a construção da liberdade e da cidadania do outro como condição mesma de realização de sua própria liberdade e cidadania (COELHO, 1996, p.37).

O processo de ensino-aprendizagem, para ser bem-sucedido, deverá levar em consideração o processo de desenvolvimento cultural do ser humano, seu ritmo de aprendizados e, principalmente, não poderá acontecer dissociado da realidade social em 
virtude do crescimento das inovações tecnológicas e dos novos modos de organização de produção.

Oportuno salientar também que, a relação da formação do professor e o processo de ensino-aprendizagem se dão em contexto amplo, ou seja, existem variáveis que não dependem apenas do professor para que o aluno aprenda é preciso tempo, espaço e currículo adequado e, principalmente, de suporte Institucional que colabore na resolução de problemas e entraves.

Nessa concepção, promover o desenvolvimento é favorecer situações de aprendizagem, reconhecendo o que já foi alcançado e prover mecanismos e meios de investimentos para as etapas seguintes.

Assim, para aprimorar o processo de ensino-aprendizagem é necessário o desenvolvimento de habilidades, a busca por diferentes saberes possibilitando essa (re) construção, conforme revela Pimenta:

Por isso, a finalidade da Educação Escolar na sociedade tecnológica, multimídia e globalizada, é possibilitar que os alunos trabalhem os conhecimentos científicos e tecnológicos, permitindo que haja o desenvolvimento de habilidades para poder operá-los, revê-los e reconstruílos com sabedoria. O que implica analisá-los, confrontá-los e contextualizálos. Para isso, há que os articular em totalidades que permitam aos alunos irem construindo a noção de cidadania mundial (PIMENTA, 1999, p. 29).

Esses aspectos demonstram a necessidade do educador efetivar uma prática pedagógica atrativa, dinâmica que conduzam os educandos por caminhos diferentes e convergem para um ensino significativo e, especialmente que passem a adquirir uma visão de mundo mais integradora, conforme elucidado nas palavras do professor Coelho (1996) "Formação não é o simples repasse de informação. Para obter informação, nem é preciso ir à escola. Escola é para ensinar a pensar o mundo de forma mais crítica".

Constata-se que, diante da expansão da Educação Profissional e Tecnológica nestes últimos anos e a consequente ampliação do número de docentes exigidos para atender esta demanda, reforça e justifica ainda mais a necessidade de investir na formação de professores, formadores de profissionais, potencializando o senso de responsabilidade, solidariedade, afetividade e o sentimento de justiça, competências essas inerentes tanto à pessoa do docente como de qualquer outro profissional, assegurando sua efetiva inserção no mercado do trabalho diante do contexto social emergente. A professora e pesquisadora, Cleunice Rehem, em seu livro Perfil e Formação do Professor de Educação Profissional e Técnica, sinaliza essa necessidade de mudança: 
[...] a formação profissional centrada no ensino de técnicas, na transmissão de conhecimento, na fragmentação disciplinar, na dicotomia teoria/prática, na pedagogia de trabalho taylorista/fordista, nas séries metódicas, não dá conta de formar o novo profissional demandado (REHEM, 2009, p.24).

Neste sentido, só reforça a compreensão que a prática educativa é um fenômeno sociocultural que envolve relações humanas e momentos de incerteza que escapam à racionalidade técnica (executores de decisões impostas). Trocando em miúdos, a formação do professor, independentemente da modalidade de educação que irá atuar, precisa estar subsidiada de competências, habilidades, capacidade de decisão no sentido de produzir novos conhecimentos para a teoria e prática de ensinar. Nessa perspectiva, a formação inicial exerce influência diretamente no exercício da docência quando lhe possibilita condições de melhor compreensão, desenvolvimento e intervenção no processo de ensino e de aprendizagem. Carvalho e Souza (2014) nos ajuda entender melhor esta questão quando diz que:

O docente que possui formação técnico-pedagógica inicial, adquirida na graduação, pode compreender o processo de ensino e de aprendizagem de maneira complexa e abrangente, visualizando este processo por meio de conhecimentos técnicopedagógicos e metodologias próprias que o auxiliam na construção e no planejamento das atividades práticas a serem desenvolvidas diariamente na sala de aula (CARVALHO \& SOUZA, 2014, p. 892).

Portanto, diante do que já foi mencionado até agora, é notório a importância da formação pedagógica não só aos professores, mas também aos pedagogos que irão atuar nesta modalidade da educação. Entretanto, os autores (ibid) ao mesmo tempo em que reconhece essa importância, questionam em referência aos currículos dos cursos de Pedagogia: [...] "o atual formato curricular da licenciatura em pedagogia seria capaz de preparar o docente da EPT, contemplando as especificidades do exercício docente[...]? ". Ressalta-se que o encaminhamento dado pelos referidos autores foi de que a "é preciso que as faculdades de educação, além dos cursos de Pedagogia repensem sua relação com esta modalidade de ensino”. Nesse sentido, Carvalho e Souza (ibid., p. 893) consideram um bom ponto de partida e esclarece que:

[...]por meio dessa aproximação o currículo desenvolvido nas faculdades de educação e o curso de Pedagogia seriam alçados a incorporar compreensivamente as funções, as estruturas, os conhecimentos e as especificidades da modalidade de formação para a EPT. A partir de uma nova orientação epistemológica seriam organizados e realizados estudos para a compreensão crítica da história e da sociologia; da antropologia e da psicologia; da gestão e das políticas; da didática e das metodologias de ensino, no contexto de EPT (CARVALHO e SOUZA, 2014, 893). 
Diante do proposto, esse seria um novo formato de formação inicial que poderia amenizar as dificuldades do profissional, ao ingressar na docência no contexto da EPT. Porém, um outro apontamento se faz necessário, a proposição de uma formação continuada, para àqueles que já encontram em plena atividade e que não obtiveram na sua graduação nenhuma formação para a docência.

A despeito disso, o diretor de Políticas da SETEC, Luiz Augusto Caldas Pereira, assim se manifestou:

\begin{abstract}
A formação pedagógica para os profissionais que atuam ou atuarão como professores do conteúdo específico da EPT, exige em primeiro lugar, das instituições que se dispuserem a esta atribuição, o comprometimento com o fortalecimento de uma cultura do valor do trabalho educativo enquanto aspecto que deve perpassar os diferentes fazeres da escola e que se paute pela permanente reflexão sobre o sentido do porquê fazemos educação neste país, algo que certamente contribuirá para modificar o perfil do profissional não só docente, mas também os técnicos administrativos que atuam na EPT(PEREIRA, 2009, p. 6 ).
\end{abstract}

Essa fala só vem a confirmar o reconhecimento da necessidade de modificação da realidade apresentada, tanto dos docentes quanto dos técnicos administrativo que também não obtiveram formação para trabalhar com a EPT.

Neste sentido, o desenvolvimento de competências pedagógicas direcionada a esse público da EPT, deverá, especialmente, atender o desafio da qualidade do ensino ofertado nos IFs, pois essas instituições assumem um papel de suma importância para o avanço do país, no desenvolvimento de ciência e tecnologia aplicada, na qualificação do cidadão brasileiro, Portanto, prover as condições e meios para que os egressos dos cursos profissionalizantes tenham condições de enfrentar as mudanças tecnológicas, sociais e econômicas que afetam o mundo do trabalho, sua mobilidade profissional e empregabilidade, deverá estar no centro das atenções dessas instituições.

O aperfeiçoamento das práticas docentes promovendo autonomia e contextualização dos diversos saberes disciplinares, integrando os conhecimentos científicos aos pedagógicos direcionando para o fortalecimento de uma cultura do valor do trabalho educativo, parece ser a saída para atender a essa complexidade.

Acreditamos que a formação continuada dos docentes de EPT, oferecida na própria instituição em que trabalham e ou em outras instituições de ensino superior, deve possibilitar uma reflexão crítica sobre sua prática pedagógica, referendá-las em concepções teóricas e em saberes da experiência que as fundamentam, de forma a superar a racionalidade técnica, a fragmentação do ensino, as práticas emergidas em meio a improvisos e assim redimensionar o processo pedagógico na Instituição. 
Diante dessas características ampliadas e diversas do perfil desejado ao professor, percebe que a formação inicial não é absolutamente suficiente, mas é tão importante quanto a formação continuada para dar conta dos desafios que o docente enfrenta no seu cotidiano de sala de aula. E, além do mais, cabe às instituições a mesma compreensão que teve Araújo (2008):

As ações de formação não asseguram per se a qualificação profissional, por isto é fundamental que suas estratégias sejam vinculadas a processos de valorização profissional e que estes se materializem no respeito ao profissional docente, na remuneração "adequada", no estabelecimento de relações respeitosas, simétricas e democráticas. Não há nada mais desqualificante que um clima institucional que desvaloriza o trabalho docente (ARAÚJO, 2008, p. 62). 


\section{PROCEDIMENTOS METODOLÓGICOS DA PESQUISA}

Partindo dos objetivos traçados e da necessidade de analisar o objeto de estudo proposto, esta pesquisa demandou uma abordagem predominantemente qualitativa com caráter descritivo, paralelamente somado ao fato da pesquisadora se encontrar, em âmbito profissional, imersa neste campo investigativo e com possibilidade favorável de observação direta e interativa de boa parte deste cenário, descrevendo de forma detalhada e conduzindo o estudo com certo rigor e postura ética em relação aos resultados que serão emergidos.

Segundo Lüdke e André (1986, p.12), nos estudos qualitativos:

[...] há sempre uma tentativa de capturar as perspectivas dos participantes, isto é, a maneira como os informantes encaram as questões que estão sendo focalizadas. Ao considerar os diferentes pontos de vista dos participantes, os estudos qualitativos permitem iluminar o dinamismo interno das situações, geralmente inacessíveis ao observador externo.

De acordo com Creswell (2013, p.24) “[...] a pesquisa qualitativa pode ser melhor, porque o pesquisador visa explorar um problema, dar vozes aos participantes, mapear a complexidade da situação e comunicar as múltiplas perspectivas dos participantes".

Conforme a finalidade desta pesquisa, a mesma é classificada como uma pesquisa aplicada que segundo Gil (2010, p.26), "abrange estudos elaborados com a finalidade de resolver problemas identificados no âmbito das sociedades em que os pesquisadores vivem".

Em relação aos objetivos, este estudo se define, assim, como pesquisa descritiva, com o objetivo de descrever características de determinada população ou ainda identificar possíveis relações entre variáveis e também como pesquisa exploratória, pois este tipo de estudo "têm como propósito proporcionar maior familiaridade com o problema, com vistas a torná-lo mais explícito ou a construir hipóteses”. (GIL, 2010, p.27).

Menga (apud MARCONI E LAKATOS, 2011, p.271) afirma que o estudo qualitativo "é o que se desenvolve numa situação natural; é rico em dados descritivos, tem um plano aberto e flexível e focaliza a realidade de forma complexa e contextualizada".

Nessa perspectiva, a caracterização da pesquisa se constitui também, como um estudo de caso uma vez que a mesma será estudada numa realidade específica, ou seja, no contexto do IFPA/Campus Conceição do Araguaia. "Estudos de caso são aqueles nos quais o pesquisador explora em profundidade, um programa, um fato, uma atividade, um processo ou uma ou mais pessoas" (CRESWELL, 2010 p.32). 
Segundo Stake (apud ANDRÉ, 2013, p.97) "Estudo de caso não é uma escolha metodológica, mas uma escolha do objeto a ser estudado”. E ainda segundo André (2013, p. 97) “O conhecimento gerado pelo estudo de caso é diferente do de outros tipos de pesquisa porque é mais concreto, mais contextualizado e mais voltado para a interpretação do leitor”.

Gil (2010) colaborou na fundamentação desta caracterização quando diz:

Os estudos de caso requerem a utilização de múltiplas técnicas de coleta de dados. Isso é importante para garantir a profundidade necessária ao estudo e a inserção do caso em seu contexto, bem como conferir maior credibilidade aos resultados. (GIL, 2010, p. 119).

Entende-se, que a abordagem qualitativa proporciona melhores possibilidades de exploração de respostas aos objetivos propostos no estudo, utilizando-se para isso de diferentes técnicas de coleta de dados junto aos sujeitos da pesquisa.

\subsection{Caracterização da Instituição e Município - lócus da pesquisa}

Antes de contextualizar a Instituição se faz pertinente caracterizar o município onde a Instituição está instalada. O município de Conceição do Araguaia faz parte de uma das seis mesorregiões do Estado do Pará, o qual se localiza na região norte do Brasil. Este município se localiza especificamente na região sudeste do estado do Pará. Cidade centenária, atualmente com seus 118 anos de fundação, a qual foi fundada em 30 de maio de 1897, pelo religioso francês Frei Gil de Vila Nova.

Conceição do Araguaia está situada à margem esquerda do majestoso Rio Araguaia, fazendo divisa com o estado do Tocantins. O nome Conceição é português. Trata-se de uma homenagem à padroeira da localidade, Nossa Senhora da Conceição. Araguaia é expressão tupi que, segundo Theodoro Sampaio, significa "Rio do vale dos Papagaios". Possui uma população estimada de 46.395 habitantes, segundo dados do IBGE/2015. Sua população maior se concentra na zona urbana, porém, $28,72 \%$ pertencem à zona rural.

A economia do município gira em torno da agricultura e pecuária de corte com grande potencial para indústria na área do couro, possuindo possibilidades reais de crescimento e desenvolvimento. O Índice de Desenvolvimento Humano-IDH do município calculado no ano de 2010 era de 0,64. (IBGE, 2015). 
O Campus do Instituto Federal-IF será o lócus da pesquisa. Em âmbito nacional, essa denominação de Instituto Federal, ocorreu em 2008, em virtude da Lei 11.892/2008, que criou a Rede Federal de Ensino, e os define da seguinte forma:

[...] Art. 2o Os Institutos Federais são instituições de educação superior, básica e profissional, pluricurriculares e multicâmpus, especializados na oferta de educação profissional e tecnológica nas diferentes modalidades de ensino, com base na conjugação de conhecimentos técnicos e tecnológicos com as suas práticas pedagógicas [...] (BRASIL,2008).

As finalidades da Instituição ficaram estabelecidas nesta lei, dentre as quais destacamos as duas que mais interessa para este estudo:

[...] I - ofertar educação profissional e tecnológica, em todos os seus níveis e modalidades, formando e qualificando cidadãos com vistas na atuação profissional nos diversos setores da economia, com ênfase no desenvolvimento socioeconômico local, regional e nacional;

II - desenvolver a educação profissional e tecnológica como processo educativo e investigativo de geração e adaptação de soluções técnicas e tecnológicas às demandas sociais e peculiaridades regionais; [...] (BRASIL, op. cit.)

Nesse Contexto, o registro da história do IF, no estado do Pará, consta que o Instituto Federal de Educação, Ciência e Tecnologia do Pará-IFPA, foi criado a partir da união do Centro Federal de Educação Tecnologia do Pará-CEFET, das Escolas Agro técnicas de Castanhal e de Marabá, em decorrência do plano de expansão da Rede Federal de ensino.

O IFPA possui atualmente 18 (dezoito) Campi, o de Abaetetuba, Ananindeua, Altamira, Belém, Bragança, Breves, Cametá, Castanhal, Conceição do Araguaia, Itaituba, Industrial Marabá, Rural Marabá, Óbidos, Paragominas, Parauapebas, Santarém, Tucuruí e Vigia. Todos distribuídos nos municípios do Estado e subordinados a Reitoria do IFPA localizada em Belém, capital do Estado que dista aproximadamente a 1.100km do Campus Conceição do Araguaia, lócus da pesquisa.

Historicamente, a origem da implantação do Campus em Conceição do Araguaia, se deu em detrimento de ter sido, no primeiro semestre de 2001, implantado pelo Reitor Prof. Edson Ary, um "Centro Avançado", inicialmente, ofertando 01(uma) turma do Curso Técnico em Aquicultura, com 52(cinquenta e dois) alunos matriculados, funcionando em salas emprestada no prédio da Secretaria Municipal de Educação. Entretanto, os cursos foram interrompidos neste mesmo ano, segundo relatos dos gestores anteriores por motivos de descumprimento por parte da prefeitura municipal de sua coparticipação em disponibilizar a logística necessária para o funcionamento. No entanto, por força de reivindicações 
formalizadas pelos alunos junto a prefeitura e gestor do Centro Avançado. retornou-se às atividades no ano de 2005.

Diante do retorno das atividades, também consta que, no ano de 2006, foram ofertadas mais duas turmas do mesmo curso. Com o levantamento de dados, constata-se um dilatamento para a conclusão desse curso, pois todos os alunos dessas turmas, inclusive da primeira, de 2001, concluíram e foram certificados somente no ano de 2007, curso este, de duração regular prevista de 01 (um) ano e 1/2(meio) concluída no período de 06(seis) anos.

No início de 2008, em detrimento do Plano de Expansão da Rede Federal de Educação Profissional, o Centro Federal de Educação Tecnológica do Pará - CEFET/PA formaliza a criação da Unidade de Ensino Descentralizada-UNED no município de Conceição do Araguaia, a qual inicia suas atividades lançando quatro cursos técnicos de nível médio nas modalidades Subsequentes, a saber: Técnico em Agrimensura, Técnico em Agropecuária, Técnico em Edificações e Técnico em Saneamento. Porém, antes mesmo de findar o ano de 2008, através da Lei Federal nº 11.892 de 29/12/2008, as Unidades Descentralizadas de Ensino (UNED's), deixaram de existir com esta denominação e passaram a ser denominadas de Institutos Federais de Educação, Ciência e Tecnologia - IFs, vinculados ao Ministério da Educação, a qual em seu artigo $5^{\circ}$, inciso XX diz que esta criação se dará "mediante integração do Centro Federal de Educação Tecnológica do Pará e das Escolas Agrotécnicas Federais de Castanhal e de Marabá".

Nesse contexto, o Plano de Desenvolvimento do Campus, revela que a transição de UNED's para campus foi acompanhada de duas audiências públicas, a primeira já realizada no ano de 2008 quando foram definidos os quatro cursos citados anteriormente e, em detrimento da oferta desses cursos, se estimou a quantidade de profissionais que seriam necessários para compor o quadro de vagas para o primeiro concurso, este, realizado neste mesmo ano de 2008. A segunda audiência pública aconteceu em 2009, onde foram definidas as implantações dos cursos técnicos em Eventos, Segurança do Trabalho e os cursos superiores em Agronomia e Gestão Ambiental, a fim de suprir uma grande carência da região.

Neste período, esta Instituição de Ensino no Estado do Pará, o IFPA, já contava com 11(onze) campi, dentre eles o referido Campus Conceição do Araguaia e, no ano de 2014, o número de campi em funcionamento já saltou para 18 (dezoito) com mais 27(vinte e sete) Pólos e 39(trinta e nove) unidades remotas distribuídas nas regiões em que não tem a estrutura física dos Campi. Conforme representado na figura 1, o mapa, demarcando essa expansão. 


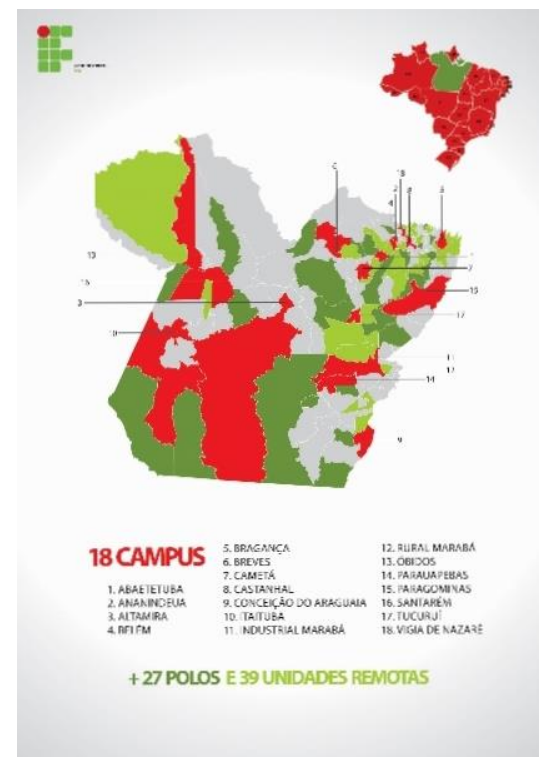

Fonte: site do IFPA,2015

A Instituição, IFPA/CDA, da forma como está concebida segundo o prescrito no seu PPP (2013) tem a missão de "Ofertar educação profissional e tecnológica nos seus diferentes níveis e modalidades, associados ao ensino, pesquisa e extensão, para a formação de cidadãos qualificados e comprometidos com a inclusão social e o desenvolvimento socioambiental regional" e sua visão em "ser referência em educação profissional e tecnológica nos diferentes níveis e modalidades de ensino”.

O campus Conceição do Araguaia está funcionando com um total de 74 (setenta e quatro) servidores, sendo 38 (trinta e oito) são servidores administrativos e 36 (trinta e seis) são docentes. Desses docentes - em relação a formação dos mesmos que faz parte do objeto de estudo - 29 (vinte e nove) possuem formação a nível de bacharelado; 06(seis) licenciados e 01(um) tecnólogo.

Em termos de infraestrutura predial, o campus conta com uma excelente infraestrutura, salas do bloco administrativo e pedagógico climatizadas (sendo 12 salas de aula amplas e arejadas com carteiras e quadro branco), biblioteca com um razoável acervo de livros, periódicos, computadores com acesso à internet; Auditório com capacidade para 250 (duzentos e cinquenta) pessoas sentadas, dois laboratórios de informática, área de convivência bem ampla, uma cantina, e o espaço do almoxarifado e alguns laboratórios de cursos. 
Atualmente, os cursos regulares, ofertados na instituição estão funcionando, distribuídos nos três turnos, atendendo aos dois níveis: Educação Profissional técnica de nível médio e Curso Superior como consta no Quadro1.

Quadro 1: Distribuição por nível, curso, modalidade, quantitativo de turmas de cada curso e seus respectivos turnos de funcionamento em 2015

\begin{tabular}{|c|c|c|c|}
\hline Níveis & Cursos & Modalidades & Turmas/Turnos \\
\hline \multirow{7}{*}{$\begin{array}{c}\text { Educação } \\
\text { Profissional } \\
\text { Técnica de } \\
\text { Nível Médio }\end{array}$} & & \multirow{2}{*}{$\begin{array}{l}\text { Técnico. Integrado } \\
\text { ao Ensino Médio }\end{array}$} & 01/Matutino-Vespertino \\
\hline & Técnico em Edificações & & (período Integral) \\
\hline & Técnico em Agrimensura & & 01/Vespertino \\
\hline & Técnico em Agropecuária & Técnicos & 01/Matutino \\
\hline & Técnico em Saneamento & Subsequentes & 02/Noturno \\
\hline & Téc. em Segurança do Trabalho & Ensino Médio & 02/Noturno \\
\hline & Técnico em Marketing & & 01/Vespertino e 01/Noturno \\
\hline \multirow{3}{*}{$\begin{array}{c}\text { Curso } \\
\text { Superior }\end{array}$} & Tecnólogo em Gestão Ambiental & \multirow{3}{*}{ Tecnologia } & 03/Matutino \\
\hline & Bacharel em Engenharia Agronômica & & 05/Matutino e \\
\hline & & & (período Integral) \\
\hline
\end{tabular}

Fonte: Dados da pesquisa/Secretaria Acadêmica do Campus, 2015.

Em relação ao quantitativo de alunos, elaborou-se um quadro com o número de matrícula inicial dos cursos técnicos subsequentes em andamento distribuídos por curso e turno de funcionamento.

\begin{tabular}{|l|c|c|c|}
\multicolumn{2}{|c|}{ Quadro 2: Distribuição por curso, turno, matricula inicial e alunos frequentes } \\
\hline \multicolumn{1}{|c|}{ Cursos } & Turno & $\begin{array}{l}\text { Matrícula } \\
\text { Inicial }\end{array}$ & $\begin{array}{l}\text { Alunos } \\
\text { frequentes dez/2015 }\end{array}$ \\
\hline Técnico em Agropecuária & Manhã & 37 & 17 \\
Técnico em Marketing & Tarde & 26 & 16 \\
Técnico em Segurança do trabalho & Noite & 40 & 26 \\
Técnico em Saneamento & Noite & 38 & 30 \\
Técnico em Marketing & Noite & 39 & 22 \\
\hline \multicolumn{2}{|c|}{ Total } & 180 & 111 \\
\hline
\end{tabular}

Fonte: Dados da pesquisa/Secretaria Acadêmica do Campus, 2015

Para obter um panorama geral, elaborou-se uma Tabela com quantitativo de alunos que já foram formados pelo IFPA/CDA, desde o ano que iniciou as atividades na Instituição. A Tabela 1, na sequência, representa a quantidade de alunos ingressantes por turma no ensino técnico subsequente, e seus respectivos quantitativos de concluintes. 
Tabela 1: Cursos ofertados por ano, turma, alunos e concluintes do IFPA/CDA de 2001 a 2015

\begin{tabular}{|c|c|c|c|c|c|c|}
\hline \multirow{3}{*}{$\begin{array}{c}\text { Ano de } \\
\text { oferta }\end{array}$} & \multicolumn{3}{|c|}{ Cursos ofertados } & \multicolumn{3}{|c|}{ Quantitativo de alunos } \\
\hline & \multirow[b]{2}{*}{ Denominação da turma } & \multicolumn{2}{|c|}{ Turmas } & \multirow[b]{2}{*}{ Ingresso } & \multicolumn{2}{|c|}{ Conclusão } \\
\hline & & Turma & Turno & & $\begin{array}{c}\text { Total de } \\
\text { concluintes }\end{array}$ & $\begin{array}{c}\text { Ano de } \\
\text { conclusão }\end{array}$ \\
\hline $2001 / 1$ & Aqüicultura & F1571NA & Noite & 52 & 19 & $2007 / 1$ \\
\hline $2006 / 2$ & Aqüicultura & F1571NB & Noite & 35 & 24 & $2007 / 2$ \\
\hline $2006 / 2$ & Aqüicultura & $\mathrm{F} 1571 \mathrm{NC}$ & Noite & 44 & 30 & $2007 / 2$ \\
\hline $2008 / 2$ & Edificações & F148MC & Manhã & 36 & 23 & $2010 / 1$ \\
\hline $2008 / 2$ & Saneamento & F1491MC & Manhã & 34 & 24 & $2010 / 1$ \\
\hline $2008 / 2$ & Agrimensura & F1661MN & Manhã & 36 & 33 & $2009 / 2$ \\
\hline $2008 / 2$ & Agropecuária & F351MC & Manhã & 31 & 14 & $2010 / 1$ \\
\hline $2008 / 2$ & Agropecuária & F351NC & Noite & 30 & 24 & $2010 / 1$ \\
\hline $2010 / 1$ & Segurança do trabalho & F109TD & Tarde & 40 & 31 & $2011 / 1$ \\
\hline $2010 / 1$ & Agrimensura & F1661TD & Tarde & 44 & 33 & $2011 / 1$ \\
\hline 2010/1 & Eventos & F1341TD & Tarde & 36 & 34 & $2011 / 1$ \\
\hline $2010 / 1$ & Eventos & F1341ND & Noite & 45 & 26 & $2011 / 1$ \\
\hline $2010 / 1$ & Edificações & F148ND & Noite & 45 & 26 & $2011 / 1$ \\
\hline $2010 / 1$ & Saneamento & F1491ND & Noite & 41 & 30 & $2011 / 1$ \\
\hline $2011 / 2$ & Saneamento & F1501MA & Manhã & 29 & 17 & $2013 / 1$ \\
\hline $2011 / 2$ & Agropecuária & F351MD & Manhã & 40 & 29 & $2012 / 2$ \\
\hline $2011 / 2$ & Segurança do trabalho & F109NE & Noite & 41 & 39 & $2013 / 1$ \\
\hline $2012 / 1$ & Edificações & F148ME & Manhã & 23 & 16 & $2013 / 1$ \\
\hline $2012 / 1$ & Segurança do trabalho & F109TE & Tarde & 40 & 31 & $2013 / 2$ \\
\hline $2012 / 1$ & Agrimensura & F1661TE & Tarde & 37 & 21 & 2013/1 \\
\hline $2012 / 1$ & Edificações & F148NE & Noite & 44 & 20 & 2013/1 \\
\hline $2012 / 1$ & Eventos & F1341NE & Noite & 40 & 28 & $2013 / 1$ \\
\hline $2013 / 2$ & Edificações & F148MF & Manhã & 38 & 24 & $2015 / 1$ \\
\hline $2013 / 2$ & Agropecuária & F351ME & Manhã & 37 & 28 & $2015 / 1$ \\
\hline $2013 / 2$ & Agrimensura & F1661TF & Tarde & 32 & 22 & $2015 / 1$ \\
\hline $2013 / 2$ & Saneamento & F1501NB & Noite & 41 & 33 & $2015 / 1$ \\
\hline $2014 / 1$ & Segurança do trabalho & F1091NF & Noite & 44 & - & - \\
\hline $2013 / 2$ & Agropecuária & F351MF & Manhã & 37 & - & - \\
\hline $2015 / 2$ & Marketing & F1971TA & Tarde & 26 & - & - \\
\hline $2015 / 1$ & Segurança do trabalho & F1091NG & Noite & 40 & - & - \\
\hline $2015 / 1$ & Saneamento & F1501NC & Noite & 38 & - & - \\
\hline $2015 / 1$ & Marketing & F1971NA & Noite & 39 & - & - \\
\hline & & & TOTAL & 1.215 & 679 & - \\
\hline
\end{tabular}

Fonte: Dados da pesquisa/Secretaria Acadêmica do Campus, 2015. 
Constatamos, pelos dados representados na Tabela 1, que o quantitativo de alunos concluintes do primeiro curso ofertado na Instituição, revela um percentual consideravelmente alto de evasão, em torno de 44,35\%, (percentual das três primeiras turmas ingressantes do ano 2001/2006). No Cômputo geral, desde as primeiras turmas até os concluintes de 2013, o percentual de evasão fica em torno de $34,39 \%^{5}$, ou seja, ainda continua um índice elevado e convém averiguar, apesar do foco deste estudo não estar direcionado a questão da evasão, mas, entretanto, poderá permitir ter uma noção geral da realidade apresentada.

Por outro lado, através do conhecimento desses dados, poderá estar sinalizando para que os profissionais da Instituição possam refletir sobre as possíveis causas, nas suas mais diferenciadas dimensões, se é de ordem da gestão e estrutura dos cursos, de oferta de cursos que não atende aos anseios dos alunos, de ordem financeira, incompatibilidade de horário em virtude do trabalho, se é de ordem pedagógica, por não ter adaptado ao ritmo do curso, por apresentar dificuldades de aprendizagem, entre tantos outros motivos e, assim, poder realizar um trabalho para reverter essa situação e implementar ações mais efetivas e diretivas de acompanhamento do cotidiano escolar, com ações pedagógicas e assistenciais, que impeça que o índice de evasão continue nessas proporções.

\subsection{Sujeitos da pesquisa e Instrumentos de Coleta de dados}

Segundo Chizzotti (2006, p. 51) "A coleta de dados é a etapa da pesquisa que exige um grande volume de tempo e trabalho para se reunir as informações indispensáveis à comprovação das hipóteses".

Foram analisados alguns documentos institucionais e os sujeitos da pesquisa foram os docentes e discentes dos cursos de Educação Profissional Técnica de Nível Médio, na modalidade de técnicos subsequentes. Embora, registra-se que, num primeiro momento realizou um levantamento junto a Coordenação de Gestão de Pessoas - CGP, para construir o perfil e itinerário formativo de todo o corpo docente da Instituição.

Logicamente, para dar início a esse levantamento de dados, realizou-se contato verbal e formal ${ }^{6}$ com a direção geral do Campus que se manifestou totalmente favorável com a proposta de estudo.

\footnotetext{
${ }^{5}$ Realizou-se este cálculo tirando a porcentagem do total de 1.035 alunos, dos anos de 2001 a 2013 , em virtude dos alunos matriculados nos anos subsequentes ainda não terem concluído, até o final da pesquisa.

${ }^{6}$ Ofício disponível no Apêndice "A".
} 
No mês de novembro do ano de 2014, foi dado início a coleta de dados, realizando, preliminarmente, o levantamento e registro de informações junto à Coordenação de Gestão de Pessoas - CGP, possibilitando a descrição e quantificação do número de professores para o delineamento e construção do perfil e itinerário formativo de todo o corpo docente.

Durante o ano de 2015, prosseguiu-se com a coleta e análise dos documentos institucionais: Plano de Desenvolvimento Institucional (PDI); Plano de Desenvolvimento do Campus (PDC); Projeto Político Pedagógico (PPP); Projeto Pedagógico dos Cursos (PPC), assim como leis, decretos, pareceres e editais de concurso para docentes que continham elementos que pudessem colaborar com o objeto de estudo e, por fim, foram analisados os Projetos Pedagógicos dos Cursos (PPC) de todos os cinco cursos técnicos subsequentes em andamento para averiguar se teria alguma referência sobre o objeto de estudo, principalmente para compreender as habilidades e competências delineadas para seus egressos, as quais possuem relação direta com o processo ensino-aprendizagem.

Em relação ao embasamento empírico junto aos docentes, a técnica de coleta de dados utilizada foi através de entrevistas semiestruturadas, as quais continham um roteiro préestabelecido realizado com 6 (seis) professores selecionados intencionalmente, sendo 3 (três) professores graduados, a nível de Bacharelado e 3 (três) professores com formação no formato de Licenciatura Plena, representando uma amostra igual aos dois perfis de formação que prontamente aceitaram participar da pesquisa assinando o TCLE ${ }^{7}$.

A seleção da caracterização dessa amostra, em relação aos dois perfis, se deu de forma intencional, em virtude da necessidade de coletar a percepção dos dois perfis de professores em relação a sua formação para atuar na Educação Profissional e Tecnológica. A seleção intencional da amostra, segundo Creswell (2013 p. 157), acontece quando leva em consideração que “[...] os participantes experienciaram o fenômeno central ou o conceito chave que está sendo explorado no estudo" E, ainda segundo este mesmo autor:

\footnotetext{
[...]a ideia que está por trás da pesquisa qualitativa é a seleção intencional dos participantes ou dos locais (ou dos documentos ou do material visual) que melhor ajudarão o pesquisador a entender o problema e a questão da pesquisa (CRESWELL, 2010, p.212).
}

Portanto, a escolha desse instrumento de pesquisa foi embasada na possibilidade de coletar, sem intermediação, ou seja, coletar as percepções diretamente na fonte, no caso, diretamente com os professores e alunos.

\footnotetext{
${ }^{7}$ O TCLE-Termo de Consentimento Livre e Esclarecido está disponível no Apêndice"C"
} 
A elaboração do roteiro das entrevistas foi embasada no referencial teórico e também com foco nos objetivos específicos delineados para este estudo de construir o perfil de formação dos professores bem como identificar as percepções dos mesmos sobre sua formação e as implicações na prática pedagógica.

Nesse contexto, o roteiro de entrevistas ${ }^{8}$ continha três eixos temáticos principais, com questões específicas que o professor abordaria livremente sobre seu universo pessoal e profissional, nos seguintes aspectos: I-Processo formativo, II-Atuação e trajetória profissional e as III-Práticas pedagógicas no ensino técnico subsequente e o contexto institucional. Optouse por gravar as falas dos professores, com consentimentos dos mesmos, para garantir uma maior preservação dos discursos. Além disso, permitir a interação com o entrevistado, bem como nortear, no momento da análise, a compreensão do fenômeno pesquisado.

Nesse contexto, as falas foram gravadas, utilizando-se, para isso, um aparelho celular que continha esta função em seus aplicativos. A duração de cada entrevista, variou-se em média de uma hora a uma hora e meia. Posteriormente, esses áudios foram transcritos na íntegra que, ao final, totalizaram 90 (noventa) páginas, as quais serviram para análise e sistematização dos resultados.

Para coletar as percepções dos alunos sobre o processo ensino-aprendizado adquirido na instituição, a princípio, pretendia-se realizar a técnica do grupo focal, tanto que foi elaborado o roteiro para reunião com esse grupo focal por entender que esta técnica facilitaria a espontaneidade nas falas e no relato de experiências quando desenvolvidas no contexto de um grupo com afinidades e características comuns. Porém, devido a Instituição se encontrar em greve, não foi possível reunir os alunos, embora, nas duas vezes em que se agendou uma reunião, num outro local, devido os alunos estarem impedidos de entrar no Campus, a reunião foi cancelada por motivos de incompatibilidade de horário entre os alunos. Assim, não sendo possível utilizar-se deste instrumento de coleta de dados previsto no projeto de qualificação, o qual foi substituído por questionário, que segundo Gil (1994) o define como uma:

[...] técnica de investigação, composta por um número mais ou menos elevado de questões apresentadas, por escrito, às pessoas, tendo por objetivo o conhecimento de opiniões, crenças, sentimentos, interesses, expectativas, situações vivenciadas, etc. (GIL, 1994, p. 124).

Definindo então nesse segundo momento, o questionário como sendo o instrumento de coleta de dados que seria aplicado aos alunos, elaborou-se as questões a partir do objetivo

\footnotetext{
${ }^{8}$ Disponível no Apêndice "D”
} 
proposto para o estudo de identificar a percepção dos discentes sobre o processo ensinoaprendizagem e também com a finalidade de estabelecer uma conexão entre a fala do professor e a percepção do aluno sobre o mesmo assunto em questão.

Esses questionários, foram enviados eletronicamente aos alunos, através da web, utilizando a ferramenta google drive que serviu para edição, formatação e envio desse formulário investigativo para os e-mails pessoais dos alunos.

Pertinente esclarecer que, inicialmente, para realizar este estudo junto aos alunos, recorreu-se a Secretaria Acadêmica da Instituição para levantamento nominal dos alunos dos cinco cursos técnicos subsequentes em funcionamento. A partir desses dados, construímos um quadro com nome, telefone, e-mail de 25 (vinte e cinco) alunos sorteados aleatoriamente, sendo 05 (cinco) alunos por curso. Após esse levantamento e definição dessa amostragem foi estabelecido contato através de ligações via celular, embora nem sempre conseguindo êxito com a totalidade da lista definida preliminarmente, em virtude de alguns celulares se encontrarem no momento desativados, fora de área de serviço entre outros contratempos.

No entanto, diante dos contatos bem-sucedidos ficou evidenciado a disponibilidade de 15 (quinze) alunos em contribuir com esse estudo que corresponde a um percentual de 13,51\% do total de alunos frequentes nos cursos técnicos subsequentes (Quadro 2). Após explanação geral do que se tratava, fez-se o convite e, nesse momento, encaminhou-se ao email pessoal a carta convite e o Termo de Consentimento Livre Esclarecido-TCLE ${ }^{9}$, no qual esclarecia que o fato de responder o questionário e enviar, postulava seu consentimento formal. O formulário ${ }^{10}$ teve um total de 15 (quinze) questões sendo, 07 (sete) perguntas fechadas, itens relacionados à identificação do participante, informações tais como: curso, módulo, nome, sexo, faixa etária, nível do último curso concluído e, se exercia alguma atividade profissional concomitante aos estudos e 08 (oito) questões abertas com assuntos específicos e direcionados para coletar informações sobre a percepção relacionada ao processo ensino-aprendizagem no contexto da Instituição.

Assim, este questionário, junto aos discentes, além de coletar as percepções dos mesmos sobre o processo ensino-aprendizagem também tinha a pretensão de, através dos cruzamentos de dados, relacionar com as falas dos professores, ou seja, analisar também as repercussões das práticas pedagógicas dos professores, conforme seu perfil de formação, na percepção dos alunos.

\footnotetext{
${ }^{9}$ Disponível no Apêndice "F".

${ }^{10}$ Disponível no Apêndice " $G$ ".
} 


\subsection{Procedimentos para a análise dos dados}

Nos documentos Institucionais utilizou o procedimento de leituras concentrando nos temas que se referiam aos aspectos da docência, temática central deste estudo. Para tanto, os dois principais temas a serem pesquisados nesses documentos foram: formação docente e ou formação pedagógica direcionada aos professores que estão atuando, bem como aos candidatos a assumir esse cargo em consequência da aprovação em concurso público. $\mathrm{O}$ apontamento delineado procurou compreender 'Como esse aspecto da formação e ou formação pedagógica desses docentes tem sido abordado, discutido nesses documentos'?

Em relação às entrevistas, partindo-se do pressuposto de que as opiniões dos professores poderiam variar sobre alguns questionamentos e conhecimentos específicos em relação às questões norteadoras do eixo temático relacionado às práticas pedagógicas no contexto institucional, utilizou-se estrategicamente a denominação dos dois perfis sendo: DB se referindo ao Docente Bacharel e DL para Docente Licenciado e o número após esta sigla ordenando sequencialmente e caracterizando em específico àquele sujeito entrevistado.

Segundo Bardin (2011) “[...] o que caracteriza a análise qualitativa é o fato da “inferência [...] ser fundada na presença do índice (tema, palavra, personagem, etc.!), e não somente a frequência da sua aparição, em cada comunicação individual”. Sendo assim, definiu-se a estratégia para identificar os dados das duas variáveis atendendo ao objetivo proposto de analisar as repercussões das práticas pedagógicas no processo ensinoaprendizagem, de acordo com a percepção de cada docente.

Para colaborar na análise do que foi observado e verbalizado nas entrevistas transcritas integralmente, elaborou-se, apenas para fins de tabulação, um quadro com a classificação dos indicadores que são as tematizações, as categorias de análises e a seleção dos possíveis depoimentos dos professores durante a entrevista que pudessem fazer parte da descrição dos resultados e da análise conforme cada perfil de professor pesquisado.

Em relação aos outros sujeitos da pesquisa, no caso, os alunos, a finalidade da análise se concentrou em identificar a percepção dos mesmos quanto ao processo ensinoaprendizagem ofertados na instituição. Assim, os dados foram tratados através da elaboração de quadros contendo o tema indicador, as categorias e subcategorias que foram analisadas através das respostas dos sujeitos da pesquisa e produzido o relatório conclusivo. Para caracterizar a origem das falas dos participantes, utilizou-se a denominação pela letra (A) seguida da numeração cronológica do total de participantes, sendo de A1 a A15. 


\section{RESULTADOS E ANÁLISE DOS DADOS COLETADOS}

Este capítulo se refere fundamentalmente sobre o tratamento dos resultados da pesquisa e terá um caráter mais descritivo e, por vez, explicativo dos fatos analisados, utilizando-se para isso, em algum momento, a transcrição de parte de textos de documentos bem como algumas falas dos entrevistados para sustentação fidedigna da real situação e análise do conteúdo das mesmas. Isso embasa o que dizem os autores sobre o fenômeno da formação docente e especificamente da formação docente em EPT.

Todo esse processo foi feito manualmente, com a pretensão de tratar as informações originais sem nenhuma redução, transformação ou abstração, ou seja, busca-se através deste procedimento qualitativo para tratamento dos dados obter uma visão do todo, e, por vez, retratar fielmente alguns aspectos da realidade do processo ensino-aprendizagem obtidas através dos protagonistas da pesquisa que são os professores e os alunos.

\subsection{Exigência de Formação para compor o corpo docente}

A intenção de propor este esse eixo temático, se origina de um dos objetivos específicos desse estudo, o qual propôs a construção do perfil de formação dos docentes do IFPA/CDA. Nesse contexto, para compreender melhor este estudo, buscou junto aos editais de concursos compreender como acontecia o processo de seleção e quais as exigências legais de formação dos candidatos, para compor o quadro de docente da Instituição.

Inicialmente, no âmbito da efetividade no serviço público, existe toda uma exigência legal para fazer parte do Quadro de Pessoal Permanente na Instituição. Outrossim, conforme o edital $\mathrm{n}^{\circ}$ 04, de 13 de maio de 2015, documento este analisado, o qual rege o Concurso Público, preconiza que o mesmo será executado pelo Instituto Federal de Educação, Ciência e Tecnologia do Pará - IFPA e compreenderá de 03 (três) etapas: sendo a primeira etapa, a Prova Objetiva, de natureza eliminatória e classificatória que abrange 40 (quarenta) questões que versarão sobre assuntos específicos de cada Área de Conhecimento, Legislação (administrativa do serviço público e educacional) e Língua Portuguesa; a segunda etapa, a Prova de Desempenho Didático também com a mesma natureza e a última, terceira etapa, a Prova de Títulos de natureza classificatória.

Esta seleção destina-se ao provimento de vagas de professores da Carreira do Ensino Básico, Técnico e Tecnológico - EBTT, na classe inicial, com o objetivo de preencher o 
Quadro de Pessoal Permanente dos diversos Campi deste Instituto. O item 2 deste edital prevê as informações do cargo e do local do Trabalho, conforme demonstrado no item abaixo:

\begin{abstract}
2.3. São atividades próprias do professor da Carreira de EBTT as pertinentes ao ensino, à pesquisa e à extensão que, indissociáveis, visem à aprendizagem, à produção de conhecimento, à ampliação e transmissão do saber e da cultura, às inerentes ao exercício das funções de direção, assessoramento, representação, chefia, coordenação e assistência na própria Instituição, integrando-se estas atribuições às definidas pela Lei ${ }^{\circ}$ 9.394/1996 para o cargo de professor, tais como: participar da elaboração da proposta pedagógica da Instituição; elaborar e cumprir plano de trabalho, segundo a proposta pedagógica da Instituição; zelar pela aprendizagem dos alunos; estabelecer estratégias de recuperação para os alunos de menor rendimento; ministrar os dias letivos e horas-aula estabelecidos, além de participar integralmente dos períodos dedicados ao planejamento, à avaliação e ao desenvolvimento profissional e colaborar com as atividades de articulação da escola com as famílias e a comunidade. Deverá atuar na educação básica e na educação profissional e tecnológica em seus diversos cursos, conforme previsto na legislação vigente (IFPA, 2015, p. 2)
\end{abstract}

Constata-se quão complexa, ampla e desafiadora é a função do professor quando ingressa na Instituição, a qual já prevê que sua atuação, de certa forma, acontecerá de forma verticalizada, pois atuará como docente em todos os níveis da EBTT, previsão esta, inclusive em acordo ao previsto na LDB 9.394/96, Capítulo III que trata especificamente e define a abrangência da Educação Profissional e Tecnológica. O art. $39^{11}$ diz que esta modalidade, [...] "no cumprimento dos objetivos da educação nacional, integra-se aos diferentes níveis e modalidades de educação e às dimensões do trabalho, da ciência e da Tecnologia". Os quais poderão ser organizados por eixos tecnológicos e abrangerá a educação básica (cursos de formação inicial ou continuada-FIC ou qualificação profissional e ensino médio integrado) cursos técnicos: (de educação profissional técnica de nível médio); e tecnológica: (cursos de educação profissional tecnológica de graduação, pós-graduação).

Entretanto, observamos no edital de concurso, mencionado anteriormente, que em relação a exigência de formação, se exige uma formação mínima, a qual será designada por área de conhecimento, ou seja, formação técnica e ou de nível tecnológico voltados para as áreas técnicas, não exigindo, neste caso, formação pedagógica para atuar na docência, conforme observado no Quadro 3, de dados extraídos deste edital.

$11 \mathrm{O}$ art.39 passa a ter nova redação e acréscimos de parágrafos, conforme a Lei $\mathrm{n}^{\circ} 11.741$, de 16 de julho de 2008 . 
Quadro 3 - Formação mínima do candidato a professor, exigida por área do conhecimento, conforme Edital de concurso $n^{\circ}$ 04/2015-IFPA

\begin{tabular}{|l|l|}
\hline \multicolumn{1}{|c|}{ Área do Conhecimento } & \multicolumn{1}{|c|}{ Formação Exigida } \\
\hline Gestão Ambiental & $\begin{array}{l}\text { Engenharia Ambiental, Ciências Ambientais ou graduação em tecnologia } \\
\text { ambiental }\end{array}$ \\
\hline Engenharia Sanitária & $\begin{array}{l}\text { Engenharia Sanitária ou Graduação em Engenharia Sanitária e Ambiental. } \\
\text { Todas com mestrado em Engenharia Sanitário ou Meio Ambiente }\end{array}$ \\
\hline Física & Licenciatura em Física \\
\hline Educação Física & Licenciatura em Educação Física \\
\hline História & Licenciatura em História \\
\hline Letras & Licenciatura em Letras com habilitação em Português e Espanhol. \\
\hline Libras & Licenciatura em Letras Libras/Língua Portuguesa ou Licenciatura com \\
& exame de proficiência em Libras promovido pelo MEC \\
\hline
\end{tabular}

Fonte: Dados da pesquisa, extraídos do Edital no 04, de 13 de maio de 2015.

Ainda sobre a questão das etapas do concurso, verifica-se que, do quantitativo das três etapas, o candidato para prosseguir nas etapas do certame, deverá obter uma pontuação mínima de 50\% de acerto na Prova objetiva, o qual obterá o direito de participar da prova de desempenho didático. Em relação a isso, o item 10.4.8 afirma em que consiste essa prova:

[...] uma aula com duração mínima de 45 (quarenta e cinco) minutos e máxima de 50 (cinquenta) minutos versada em um dos temas propostos pelo edital de convocação para cada área. Essa etapa será realizada na presença da Banca Examinadora com a finalidade de verificar os conhecimentos e o desempenho didático do candidato (IFPA, 2015, p. 15).

Nessa etapa se avalia os conhecimentos específicos da área e a capacidade pedagógica do candidato, durante uma "aula simulada", cronometrada, perante uma banca examinadora composta por DOIS especialistas da área e UM pedagogo.

A $3^{\mathrm{a}}$ (terceira) etapa consiste na prova de títulos. Nota-se que existe uma pontuação elevada para os candidatos que possuem cursos de especialização stricto sensu (mestrado e ou doutorado) e publicações científicas, ou seja, há uma irrelevância da formação pedagógica desde a seleção para o ingresso no IFPA, pois os itens experiência profissional e formação pedagógica pontuam bem menos no Cômputo para a classificação dos candidatos.

Com a intenção de ter um aprofundamento maior sobre as a informações do cargo e formação exigida para investida no mesmo, esta pesquisa se propôs a realizar um estudo minucioso comparando alguns editais de Concursos e, constata-se que houve diferenças em alguns itens desses editais. Destacam-se algumas informações de suma importância que foram complementadas nas disposições gerais de três editais de concursos analisados. 
No edital no 011/2009 consta no item 18.4 4. Que: "O candidato investido no cargo, em área específica do ensino técnico que não possua licenciatura, deverá submeter-se a preencher este requisito no prazo máximo de 23(vinte e três) meses" (grifo meus). No Edital $n^{\circ}$ 1/2013 consta no item 11.7 “o candidato investido no cargo, em área específica do ensino técnico que não possua licenciatura, fica obrigado a submeter-se ao curso de formação pedagógica com carga horária mínima de 600 horas, com início no prazo máximo de 24 (vinte e quatro) meses após o efetivo exercício”. No Edital, mais recente, n 04/2015, não foi constatado nenhuma complementação a esse respeito, apenas, nas disposições gerais, consta a exigência da formação mínima, conforme o Quadro 2, ilustrado anteriormente.

Nota-se que o edital de 2009 usa o termo “deverá submeter-se a preencher este requisito", ou seja, deixou bem claro que para sua atuação haveria necessidade de fazer uma complementação. Apesar de não ter dados concretos que confirmem ou não se esta determinação foi cumprida, haja vista, não ser o foco do estudo, apesar de possuir uma certa correlação. Nesse contexto, observa-se que a determinação contida no edital de 2013 foi a que melhor respondeu à problemática suscitada, onde sinalizava uma indicação de perspectivas de melhora neste aspecto da formação continuada do professor, entretanto, verifica-se que este item foi suprimido no edital atual.

Pelo exposto, denota que a exigência mínima de titulação nos concursos públicos que houvera para a Instituição até então, percebe-se que, o ingresso de professores se deu, na maioria das vezes, pela formação em nível de bacharelado, as engenharias entre outros cursos e, por isso, reforça ainda mais a necessidade da Instituição investir em políticas continuadas de capacitação e qualificação em serviço para possibilitar melhores condições didáticopedagógicas para o ofício da docência.

Oportuno enfatizar a existência de uma política de qualificação dos servidores, mas percebe-se que os professores ao ingressarem na Instituição, procuram se dedicar a outros níveis de estudo, mestrado e ou doutorado. Assim, a questão da formação pedagógica, acontece através de estratégias formais, em formatos fragmentados e esporádicos oferecidos pela própria Instituição através de encontros pedagógicos, palestras, seminários, mas que não suprem a carência e nem tem uma continuidade e obrigatoriedade pedagógica e Institucional.

Acreditamos que, para minimizar a grande dificuldade de profissionais que não são formados para a docência, porém, através da aprovação em um concurso assume-a, talvez seja necessário partir de exigências mais criteriosas para minimizar futuros problemas de ordem pedagógica. De que forma? Revendo essas exigências em termos de pontuar mais os 
candidatos com formação, capacitação e experiência docente seguido de experiência profissional na área de conhecimento técnico e ou tecnológico.

Face ao exposto, outra situação que poderá contribuir, sem dúvida, quando o professor já se encontrar efetivado e atuando no cargo de professor, que a Instituição exija e ou promova a oferta de cursos de formação continuada para esses professores, haja vista ser uma profissão que requer uma reflexão contínua sobre o processo e práticas educativas.

Nesta perspectiva, registra-se que houve uma tentativa da Pró-reitoria de ensinoPROEN, no ano de 2012, em desenvolver um curso de formação pedagógica para os não licenciados, o qual foi denominado de Programa Especial de Formação Pedagógica de Docentes do IFPA, o qual tinha como público alvo os portadores de diplomas de curso de nível superior (bacharel ou tecnólogos), mestres e doutores que exerciam a função de professor da EPT. Enfatiza a excelente estratégia da gestão, em oportunizar também esta formação aos profissionais que atuavam como técnicos administrativos que exercessem atividades educativas, porém, com matrícula em dois dos três módulos total do curso, desde que houvesse disponibilidades de vagas. As Inscrições foram abertas e foram selecionados os primeiros inscritos até formar o total de vagas disponíveis para cada turma.

O curso ora mencionado seria na modalidade à distância, com duração de um ano e seis meses, o qual constituía de aulas não presenciais, equivalente a $80 \%$ da carga horária total da disciplina desenvolvida em ambiente virtual de aprendizagem, através da ferramenta Moodle. Os $20 \%$ restante da carga horária de cada disciplina, corresponderia aos encontros presenciais programados, com período pré-determinado, desenvolvidos no Campus de Belém, Santarém e Conceição do Araguaia, os quais funcionariam como pólos de formação, momento em que aconteceriam as atividades teóricas e práticas das disciplinas ministradas.

Constata-se que a criação desse curso gerou uma grande expectativa positiva e, quando do início, oficialmente em 01 de abril de 2012, provocou aquele alvoroço nos participantes (cursistas) para ler o material e realizar as atividades propostas, que foram postadas com período de realização e finalização já pré-determinados. Alguns desses cursistas, professores-alunos chegaram a realizar atividades propostas da primeira disciplina, porém, não houve continuidade no curso, gerando uma certa frustação aos participantes.

Ressalta-se que, até o momento, não se sabe ao certo, sobre o real motivo do não prosseguimento desta formação. Apenas percebe-se este pesar por parte dos cursistas beneficiários, especialmente pelos ingressantes na atividade profissional da docência que buscavam aquisição de conhecimentos pedagógicos que pudessem embasar e contribuir no 
aprimoramento de sua prática pedagógica, facilitando assim o melhor desempenho do processo ensino-aprendizagem de professores e alunos da EPT.

Entretanto, percebemos que ainda existe a possibilidade de retomar esta discussão, pois na proposta de trabalho apresentada pela nova diretoria da Pró Reitoria de EnsinoPROEN, no final de 2015, consta um item que retoma essa questão, o qual propõe como ação "desenhar e efetivar o Plano de formação dos nossos docentes - Complementação Pedagógica”, mas até ao final da produção desta dissertação não havia nada de concreto, mas espera-se que tão logo seja efetivado.

\subsection{Dados do perfil e itinerário formativo dos docentes do IFPA/CDA}

O corpo docente efetivo do Ensino Básico, Técnico, Tecnológico do IFPA - Campus Conceição do Araguaia no mês de novembro de 2014, mês que deu início a coleta empírica de dados, correspondia a um total de 36 (trinta e seis) professores. Vale ressaltar que, desse total, apenas um docente estava na situação de contrato temporário, os demais, todos efetivados através de concurso público. Em relação à questão de gênero, constata-se que 20 (vinte) são do sexo masculino e 16 (dezesseis) do sexo feminino. Em relação a média de idade dos docentes, o Gráfico 1, representa a distribuição por intervalos de idade.

Gráfico 1 - Distribuição da faixa etária dos docentes do IFPA/CDA

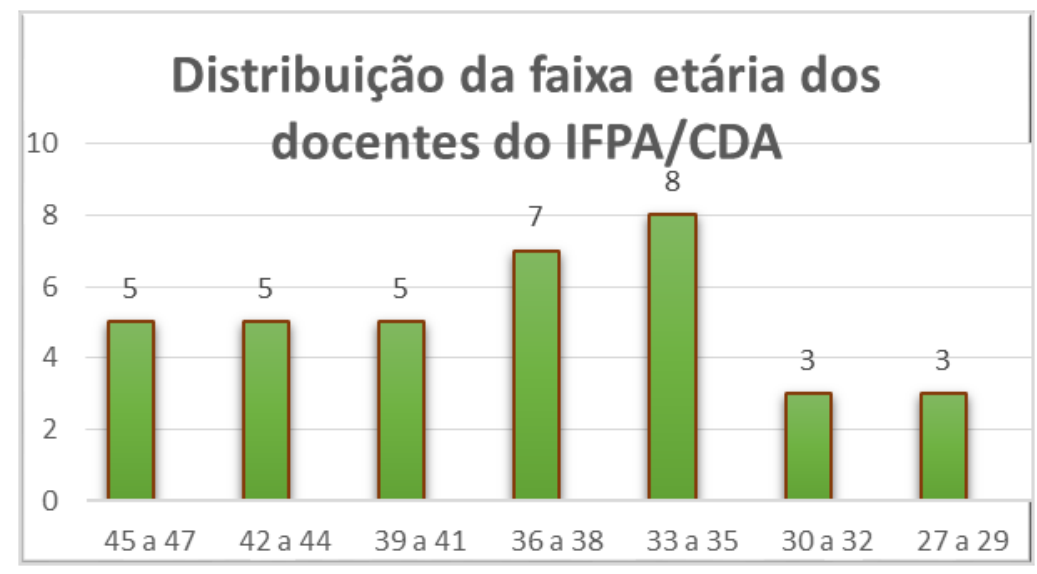

Fonte: Pesquisa de dados, 2014

Os dados demonstram que a Instituição possui um quadro de professores jovens tanto de idade quanto de carreira no magistério. Calcula-se um percentual de 58,33\% de docentes com faixa etária que variam de 27 a 36 anos de idade. 
O itinerário formativo dos docentes leva em consideração a formação inicial e continuada de todos esses docentes A Tabela 2, na sequência, representa, o perfil dos docentes, segundo a sua formação inicial e continuada, ou seja, procura demonstrar o itinerário formativo, para isso, os dados devem ser analisados verticalmente de cima para baixo, através das colunas, seguindo o perfil de formação dos professores.

Tabela 2 - Perfil Docente do IFPA/CDA: Formação Inicial e Continuada

Formação Inicial dos Docentes do IFPA/CDA

\begin{tabular}{|c|c|c|c|c|c|c|c|}
\hline \multicolumn{5}{|c|}{ Bacharel } & \multicolumn{2}{|c|}{ Licenciatura } & Tecnólogo \\
\hline \multicolumn{5}{|c|}{29} & \multicolumn{2}{|c|}{06} & 01 \\
\hline \multicolumn{8}{|c|}{ Formação Continuada } \\
\hline Lic & Esp & $M s$ & Dr. & $N P^{*}$ & Esp & $M s$ & $M s$ \\
\hline 02 & 16 & 07 & 02 & 02 & 04 & 02 & 01 \\
\hline \multicolumn{8}{|c|}{ Cursando Formação Continuada } \\
\hline- & $M s$ & $D r$. & - & - & $M s$ & - & - \\
\hline- & 07 & 04 & - & - & 02 & - & - \\
\hline
\end{tabular}

Fonte: Dados da Pesquisa de Campo, novembro de 2014.

Legenda: (Lic) Licenciatura; (Esp)Especialização;(Ms)Mestrado;(Dr.)Doutor; (NP*) Não Possui

Analisando os dados da Tabela 2, percebemos que, conforme demonstrado na $3^{\text {a }}$ linha, do total de professores da Instituição, 29 (vinte e nove) correspondente a $81 \%$ do total de professores, tiveram como formação inicial, o curso de graduação no nível de bacharel; 06 (seis) correspondem a $16 \%$ cursaram Licenciatura e 01(um) que corresponde a 3\%, possui a formação em curso superior de Tecnologia.

Analisando a primeira coluna referente à formação inicial, do total de 29 (vinte e nove) bacharéis, em relação a Formação Continuada, 02 (dois) fizeram licenciatura; 16 (dezesseis) possuem Especialização (lato sensu); 07 (sete) fizeram Mestrado; 02 (dois) fizeram Doutorado e apenas 02 (dois) ainda não possui uma formação continuada. Ainda em nível de Bacharel, dos 16 (dezesseis) que fizeram especialização, 07(sete) estão cursando Mestrado e dos 07(sete) que fizeram Mestrado, 04 (quatro) estão cursando Doutorado.

Em relação à segunda coluna da tabela, do total de 06 (seis) que possuem como formação inicial a Licenciatura, 04 (quatro) fizeram Especialização e 02 (dois) fizeram Mestrado. Dos 04 (quatro) que fizeram especialização, 02 (dois) estão cursando mestrado. A 
$3^{\text {o }}$ coluna nos mostra que o docente que tem como formação inicial o Curso Superior de Tecnologia, também investiu e continuou sua formação em nível de mestrado.

Diante desses dados, percebe-se que a maioria dos professores não ficou apenas com a Formação Inicial, mas continuou investindo na sua formação, um fator de tamanha relevância no processo de construção de sua identidade pessoal e profissional.

\subsection{Análise dos Documentos Institucionais}

Nos documentos Institucionais, pautou-se em desvelar e descrever sobre a temática central do trabalho. Segundo Gil (1994) "a análise documental é uma técnica de coleta de dados feita de forma indireta, onde as informações são coletadas por meio de documentos, registros estatísticos, $[\ldots]$ ”.

Portanto, delimitou-se dois principais indicadores e ou temas a serem pesquisados nesses documentos: formação docente e ou formação pedagógica direcionada aos professores que estão atuando bem como aos candidatos a assumir esse cargo em consequência da aprovação em concurso público.

Para isso, delinearam-se os seguintes apontamentos: Como esse aspecto da formação e ou formação pedagógica desses docentes tem sido abordado e discutido nesses 05 (cinco) documentos institucionais? O resultado desse processo analítico proposto será descrito na sequência, a partir de cada documento analisado.

a) Plano de Desenvolvimento Institucional-PDI

O PDI analisado tem como finalidade regulamentar o trabalho do Instituto norteando as ações da Gestão no período de 2014-2018, aprovado pelo Conselho Superior do IFPACONSUP através da Resolução $\mathrm{n}^{\circ} 189 / 2014$, o qual reflete sua capacidade de atender as demandas sociais baseando-se nos seguintes princípios:

a) Pensamento sistêmico: diz respeito à clareza quanto ao modus operandi da Instituição que operacionaliza suas ações após planejamento integrado entre as Próreitorias, consolidado neste PDI, oportunizando a execução e avaliação das ações de forma contínua, bem como implementando políticas adequadas e coerentes com a educação que se propõe a realizar.

b) Geração de valor: refletida na capacidade de assegurar o aumento do valor tangível e intangível da instituição. Para tanto, a instituição vem, ao longo dos anos, acumulando conhecimento sobre si mesma, sobre sua gestão e sobre seus processos, possibilitando alcançar novos patamares de reconhecimento. Agregar valor está, portanto, intimamente ligado com a sistematização estruturada, específica e proativa 
sobre o que o IFPA faz, o que permitirá chegar a resultados consistentes e satisfatórios.

c) Foco no cidadão e na sociedade: tal princípio está relacionado com a razão de existência do IFPA, a saber: ofertar serviço de qualidade, que atenda a comunidade, aos cidadãos e, portanto, a sociedade. Cabe à instituição operacionalizar com responsabilidade políticas públicas de modo a atender às demandas locais e regionais, prioritariamente.

Salienta-se que este documento foi resultado de um processo de construção coletiva de uma equipe de profissionais que utilizaram da metodologia de oficinas em doze Campi do IFPA. As quais tinham como objetivo realizar um diagnóstico, que foram sendo apontados pelos servidores e alunos da Instituição, sobre o que a comunidade do IFPA esperava da instituição, suas fragilidades, seus desafios e seus avanços. Em outro momento, foi realizado um Seminário de Planejamento com a participação da equipe gestora da Instituição: Reitor, Pró-Reitores, Diretores Gerais de Campus e Diretores Sistêmicos que, debateram e definiram os aspectos e práticas que precisavam ser realizadas, melhoradas ou eliminadas.

No momento seguinte, a equipe responsável pelo trabalho, fez a categorização das ideias, sugestões e críticas e definiram, com base nos resultados, as cinco dimensões para nortear a construção do PDI, a saber: a) Melhoria na Qualidade de Ensino Ofertado; b) Fortalecimento do Ensino, Extensão, Pesquisa e Inovação; c) Fortalecimento das políticas de acesso, permanência e Inclusão no IFPA; d) Gestão do IFPA; e, e) Responsabilidade Orçamentária e Financeira.

Observa-se que o trabalho de construção deste documento originou-se estrategicamente e esteve "embasado na legislação vigente, [...] associado ao compromisso com as exigências socioeconômicas, culturais e tecnológicas da região [...] bem como avançar como Instituição de Ensino de referência na região.

Para uma visão panorâmica e ampliada de como ficou a consolidação deste planejamento, observa-se a representação gráfica do mapa estratégico PDI 2014-2018, demonstrado na sequência na Figura 2, retirada na íntegra do Plano de Desenvolvimento Institucional do IFPA. 


\section{MAPA ESTRATÉGICO PDI 2014-2018}

\begin{tabular}{|c|c|c|}
\hline \multicolumn{3}{|c|}{ SOCIEDADE } \\
\hline MISSÃO & VISÃO & VALORES \\
\hline $\begin{array}{c}\text { Promover a educação profissional e } \\
\text { tecnológica em todos os níveis e } \\
\text { modalidades por meio do ensino, } \\
\text { pesquisa, extensão e inovação para } \\
\text { o desenvolvimento regional } \\
\text { sustentável, valorizando a } \\
\text { diversidade e a integração dos } \\
\text { saberes. }\end{array}$ & $\begin{array}{c}\text { Ser uma instituição de } \\
\text { excelência no ensino, } \\
\text { pesquisa, extensão e } \\
\text { inovação tecnológica, } \\
\text { garantindo a integração e } \\
\text { diversidade dos saberes e a } \\
\text { inclusão dos cidadãos no } \\
\text { mundo do trabalho }\end{array}$ & $\begin{array}{l}\text { Formação cidadã } \\
\text { Ética e transparência } \\
\text { Inclusão e integração da diversidade } \\
\text { Inovação Científica e Tecnológica } \\
\text { Excelência na gestão pública e } \\
\text { educacional } \\
\text { C o m p r o m i s s o c o m o } \\
\text { desenvolvimento local e regional } \\
\text { Desenvolvimento Sustentável }\end{array}$ \\
\hline
\end{tabular}

\begin{tabular}{|c|c|c|c|}
\hline \multicolumn{4}{|c|}{ ENSINO } \\
\hline $\begin{array}{c}\text { Consolidar e fortalecer os cursos } \\
\text { ofertados pelo IFPA }\end{array}$ & $\begin{array}{l}\text { Regulamenta } \\
\text { criando instrume } \\
\text { consolidação }\end{array}$ & $\begin{array}{l}\text { oferta da EAD, } \\
\text { s legais para sua } \\
\text { ambito do IFPA. }\end{array}$ & $\begin{array}{c}\text { Aumentar a oferta de cursos de } \\
\text { extensão e técnicos, como parte de } \\
\text { Programas Governamentais, a partir } \\
\text { das demandas sociais e } \\
\text { reconhecimento dos arranjos } \\
\text { produtivos locais. }\end{array}$ \\
\hline \multicolumn{2}{|c|}{$\begin{array}{c}\text { Fomentar programas e projetos de extensão, incentivando } \\
\text { e priorizando propostas vinculadas aos Projetos } \\
\text { Pedagógicos dos Cursos. }\end{array}$} & \multicolumn{2}{|c|}{$\begin{array}{c}\text { Incrementar e fomentar parcerias e cooperações nacionais } \\
\text { e internacionais, visando aumentar a qualidade da } \\
\text { formação discente do IFPA. }\end{array}$} \\
\hline
\end{tabular}

\begin{tabular}{|c|c|c|c|}
\hline $\begin{array}{c}\text { Fomentar politicas de fortalecimento } \\
\text { da Pesquisa e da Extensão. }\end{array}$ & $\begin{array}{c}\text { Criar, normatizar, regulamentar e } \\
\text { fomentar as políticas e programas } \\
\text { institucionais vinculadas à extensão, } \\
\text { no âmbito do IFPA. }\end{array}$ & $\begin{array}{c}\text { Promover a pesquisa científica e } \\
\text { tecnológica. }\end{array}$ \\
\hline Promover o ensino de Pós-graduação e a qualificação. & $\begin{array}{c}\text { Implementar um ambiente acadêmico no IFPA para } \\
\text { estimular a inovação tecnológica, sua proteção e } \\
\text { transferência para a sociedade. }\end{array}$ \\
\hline
\end{tabular}

\section{ACESSO, PERMANÊNCIA E INCLUSÃO}

Fortalecer as políticas de acesso, permanência e inclusão social no IFPA

Reduzir a taxa de evasão e retenção de alunos

\begin{tabular}{|c|c|c|c|}
\hline $\begin{array}{c}\text { Implantar a Lei de Acesso à } \\
\text { Informação }\end{array}$ & $\begin{array}{c}\text { Fortalecer as Comissões e a } \\
\text { valorização dos servidores do IFPA }\end{array}$ & Definir políticas de Comunicação Institucional \\
\hline $\begin{array}{c}\text { Ampliar a comunicação a partir } \\
\text { de Rádios, TVs educativas e a } \\
\text { participação em redes sociais e } \\
\text { outras mídias }\end{array}$ & $\begin{array}{c}\text { Desenvolver a } \\
\text { cidadania, Marketing } \\
\text { Institucional e } \\
\text { endomarketing }\end{array}$ & $\begin{array}{c}\text { Implantar o Sistema } \\
\text { Integrado de Gestão }\end{array}$ & $\begin{array}{c}\text { Nortear o desenvolvimento do } \\
\text { IFPA por meio do Planejamento } \\
\text { Estratégico }\end{array}$ \\
\hline $\begin{array}{c}\text { Aperfeiçoar a Estrutura e Funcionamento do Sistema de } \\
\text { Acompanhamento e Planejamento Orçamentário }\end{array}$ & $\begin{array}{c}\text { Instituir Sistema de Planejamento, Acompanhamento e } \\
\text { Execução Orçamentária }\end{array}$ \\
\hline
\end{tabular}

Fonte: PDI, 2015, p.28

Analisando as dimensões dispostas nesse planejamento estratégico em relação ao ensino do IFPA como um todo, a categoria que servirá de reflexão para este estudo se refere à 
Melhoria na Qualidade de Ensino Ofertado. Constatamos que, dos cinco objetivos propostos para o ensino, não possui explicitamente nenhum que indique sobre a formação pedagógica dos docentes em exercício.

Entretanto, em relação à segunda dimensão que se refere ao Fortalecimento do Ensino, Extensão, Pesquisa e Inovação, um de seus objetivos está posto como "promover o ensino de Pós-graduação e a qualificação". Embora ainda não esteja explícito, nesse primeiro momento, mas quando se refere às metas para alcançar este objetivo, fica claro que trata do corpo de servidores dos Campi. As metas traçadas foram assim discriminadas:

\begin{tabular}{|l|l|}
\hline META 1 & $\begin{array}{l}\text { Manter e ampliar os convênios de cooperação técnico-científico e educacional } \\
\text { (Minter, Dinter e cooperações) com IES públicas para a qualificação do corpo } \\
\text { de servidores do IFPA. }\end{array}$ \\
\hline META 2 & $\begin{array}{l}\text { Manter e ampliar o Programa Institucional de Qualificação (PIQ/IFPA), por } \\
\text { meio do lançamento anual de editais de bolsas de doutorado e bolsas de } \\
\text { mestrado. }\end{array}$ \\
\hline META 3 & Aumentar a oferta de cursos de pós-graduação stricto sensu. \\
\hline META 4 & Aumentar a oferta de cursos de pós-graduação lato sensu. \\
\hline META 5 & $\begin{array}{l}\text { Implantação de um sistema integrado de gerenciamento das atividades de pós- } \\
\text { graduação. Utilização completa de um sistema de gerenciamento integrado para } \\
\text { as atividades de: cadastramento cursos, servidores, alunos, bolsistas e editais. }\end{array}$ \\
\hline
\end{tabular}

Fonte: Dados da pesquisa, PDI p. 27-28, 2015

Observamos, portanto, como perspectiva favorável, pois, não somente nestas metas, mas em vários outros momentos como no item que trata sobre o Programa Institucional de qualificação-PIQ, a abertura da Instituição em contribuir com a melhoria e consolidação da EPT por meio da elevação do nível de qualificação dos docentes e técnicos administrativos que fazem a educação na instituição.

b) Plano de Desenvolvimento do Campus-PDC

Este documento possui sua primeira versão, denominada versão inicial, a qual foi elaborada no ano de 2013. Neste documento consta a missão do Campus de "Ofertar educação profissional e tecnológica nos seus diferentes níveis e modalidades, associados ao ensino, pesquisa e extensão, para a formação de cidadãos qualificados e comprometidos com a inclusão social e o desenvolvimento socioambiental regional" e sua Visão "Ser referência em educação profissional e tecnológica nos diferentes níveis e modalidades de ensino”. 
Especificamente em relação a formação dos docentes no item 7.1 que trata das Políticas de Formação dos servidores, consta-se que são políticas da Instituição:

- Proporcionar aos docentes a cada início de semestre, cursos, oficinas e palestras visando à capacitação profissional didático-pedagógica para o ensino profissionalizante e no âmbito das relações humanas;

- Socializar as experiências desenvolvidas pelos professores, com ênfase na divulgação de experiências positivas;

- Ofertar programas de formação continuada e incentivar a participação dos servidores nos eventos internos do IFPA;

- Incentivar a capacitação didático-pedagógica docente;

- Maximizar o número de servidores com pós-graduação stricto sensu (mestrado e doutorado) em suas áreas de atuação;

- Estimular a capacitação de recursos humanos através de Programas MINTER e/ou DINTER, com apoio financeiro para desenvolvimento institucional; [...] (PDC2013, p. 24).

Observamos que este documento reforça a necessidade de ações de qualificação/capacitação "[...] uma formação didático-pedagógica para os docentes que atuam nos níveis técnico e tecnológico, além de uma redefinição de critérios e incentivos para participação em cursos, programas de pós-graduação, eventos técnico-científicos".

Essa situação demonstra que a Instituição se predispõe a investir em formação pedagógica aos seus professores. Prova disso, percebemos pela proposta de trabalho da PROEN comentada anteriormente.

\section{c) Projeto Político Pedagógico-PPP}

O PPP apresenta as diretrizes, concepções filosóficas e os eixos orientadores que possibilitam o cumprimento do papel da Instituição IFPA/CDA. Na caracterização desse projeto consta que, o mesmo foi construído no ano de 2013 por representantes dos docentes e técnico-administrativos, discentes e representantes da comunidade externa, no qual propõe seu comprometimento de ofertar uma "formação baseada na ética e na cidadania, aliada ao conhecimento científico e tecnológico, que visa à melhoria das condições de vida da sociedade brasileira, o desenvolvimento socioambiental e a inclusão social".

O PPP apresenta em "uma versão inicial que deverá ser revista e atualizada a cada ano, considerando-se a necessidade de sintonizar-se com as constantes mudanças científicas, tecnológicas e sociais que têm impacto na educação superior”. Embora, previsto a revisão anual, neste ano de 2015 a versão vigente ainda está sendo a inicial. Observamos a 
congruência com o PDC na delimitação de seus pressupostos, princípios e políticas institucionais que norteiam as práticas acadêmicas.

Em relação às políticas de ensino, pesquisa e extensão (item 8.3.3) propõe a possibilidade de ofertar cursos de pós-graduação lato sensu, (especialização) pelo próprio Campus, através de parcerias com outras Instituições de ensino e pesquisa regionais e nacionais, os quais "visam à capacitação e atualização de graduados que desenvolvem atividades na docência elou profissionais, sendo ofertados no município de Conceição do Araguaia, em períodos regulares".

Nesses pressupostos, percebemos também que há uma certa abertura para capacitação e atualização dos servidores, porém sentiu-se falta de uma projeção mais concreta para que isso venha a ser consolidado.

\section{d) Projetos Pedagógicos dos Cursos-PPCs}

Realizamos uma leitura minuciosa de todos os PPCs dos cursos técnicos subsequentes e neles estão dispostos os objetivos e justificativas para implantação e oferta dos Cursos na Instituição, bem como sua formatação, estrutura de funcionamento, matriz curricular, ementário das disciplinas e os perfis almejados para seus egressos. Estes documentos, especificamente, tratam das questões inerentes ao funcionamento do curso, portanto, nenhum deles tratou dos aspectos da formação docente e ou formação pedagógica.

Nos perfis esperados aos egressos, salvo as especificidades de cada curso, o que generaliza a quase todos, são, principalmente, as competências básicas previstas para o profissional deste século XXI, algumas delas são: condições de desenvolver suas atividades profissionais com dinamismo, ética, respeito, iniciativa, criatividade, capacidade de trabalhar em equipe, espírito empreendedor, sociabilidade e liderança.

Diante disso, acredita-se que, conseguindo êxito no estabelecimento efetivo dessas competências e das específicas de cada curso técnico, sem sombra de dúvidas, os egressos da Instituição terão aumentado suas chances de obter sucesso no mundo de trabalho.

\subsection{Dados e análise relativo às entrevistas com os docentes}

A caracterização da amostragem foi de forma intencional. Definimos, então, que seria entrevistada a mesma quantidade de cada perfil. Ficando então estabelecido o total de 06 
(seis) professores que corresponde a 16,67\% do total de professores da Instituição, sendo 03 docentes licenciados e 03(três) docentes bacharéis. Assim, procedeu-se com a colocação dos nomes dos 36 professores num recipiente e, aleatoriamente, sorteou-se um por vez, até que formasse os 03(três) de cada perfil (DB e DL).

Para elaboração do roteiro das entrevistas, elaborou-se as questões norteadoras, divididas em três eixos temáticos, a saber: $\mathrm{O}$ primeiro sendo o processo formativo do professor, o segundo, atuação e trajetória profissional e o terceiro eixo teve como foco identificar a percepção dos professores quanto ao processo ensino-aprendizagem, sua prática pedagógica e o contexto institucional nesse processo formativo.

Os docentes selecionados foram informados e, prontamente, aceitaram o convite em participar da pesquisa e conceder a entrevista, as quais foram formalizadas e agendadas com antecedência e ocorreram na própria Instituição, apenas uma entrevista, houve necessidade de ser realizada na residência do docente. Antes de iniciar as entrevistas, informamos ao docente que a mesma seria gravada e serviriam para subsidiar a análise dos dados e seus nomes não seriam divulgados, informando-os que suas identidades pessoais seriam preservadas.

Para tanto, sem nomeá-los, utilizamos para análise as siglas de identificação dos dois perfis de professores: Sendo DL (Docente Licenciado) DB (Docente Bacharel) apenas numerando de 1 a 3 cada professor no seu respectivo perfil.

Todas as entrevistas foram gravadas, tiveram uma duração, em média, de uma a uma hora e meia. Em outro momento, procedeu-se com a transcrição a partir dos áudios. Esse procedimento foi bem moroso, uma vez que o quantitativo de questões já era extenso, e, algumas falas ficaram com um áudio baixo e isto fez com que fosse necessário repeti-lo diversas vezes. Além disso, ainda houvera momentos de interação com o entrevistado que contribuiu para um prolongamento ainda maior nas falas dos docentes, devido às interferências e interpelações provocadas pela pesquisadora. Ao final, totalizaram 90 (noventa) páginas de texto transcrito.

Considerando os objetivos propostos e a divisão da entrevista por eixos temáticos, utilizamos do procedimento de análise de conteúdo, obedecendo uma certa estrutura, respeitando-se as falas dos entrevistados com o propósito de realizar as inferências em cada aspecto pesquisado. Conforme definido por Bardin (2011) sobre a definição de análise de conteúdo sendo: 
indicadores (quantitativos ou não) que permitam a inferência de conhecimentos relativos às condições de produção/recepção (variáveis inferidas) dessas mensagens (BARDIN,2011, p. 48)

Segundo Alves e Silva (1992) “A análise qualitativa de dados [...] se caracteriza por ser um processo indutivo que tem como foco a fidelidade ao universo de vida cotidiano dos sujeitos [...]. "Os roteiros elaborados partiram previamente do interesse da pesquisa e se basearam em três eixos temáticos que foram sequencialmente sendo abordados por todos os entrevistados em cada categoria e subcategorias previamente elaboradas para descrição dos resultados.

a) Resultados quanto ao processo formativo dos docentes entrevistados

O primeiro eixo temático da entrevista foi categorizado como Processo de Formação, no qual foram criadas as categorias para análise: formação inicial interesse em exercer a profissão de professor, saberes fundamentais para ser um bom professor e se a formação influenciava na sua prática pedagógica.

Verificamos que apenas um docente, que tem formação inicial em nível de bacharelado, relatou que quando cursava ensino médio, manifestava essa vontade de se tornar professor, devido ter gostado da metodologia como sua professora de ensino médio ministrava as aulas que o fez gostar da disciplina da área de exatas. Entretanto, por falta de esclarecimento à época, após a conclusão do ensino médio, optou-se por fazer engenharia já que era da área de exatas, logo depois começou a trabalhar na área de construção civil, mas sem perder a vontade de lecionar matemática, a oportunidade surgiu com a indicação de um amigo, alertando-o que ele tinha o perfil para trabalhar na escola técnica. Partiu daí sua investida para se efetivar num concurso público para a docência.

A importância do professor na vida desse profissional que hoje se tornou um professor, nos faz recorrer a primeira estrofe da canção citada na epígrafe desse estudo que se trata de uma campanha, a pedido do Movimento Todos pela Educação, que ainda hoje tem veiculado através da mídia televisiva, um vídeo como forma enaltecer a importância desta profissão "A base de toda conquista é o professor... A fonte de sabedoria, o professor... Em cada descoberta, cada invenção...[...] todo bom começo tem um professor [...]. (Um bom Professor, um bom começo de autoria do Prof. Max Haetinger).

Constatamos que a forma como o professor conduz suas aulas assume uma importância fundamental na vida futura de todos seus alunos tanto para o bem quanto para o 
mal. A formação e ou transformação do cidadão, encontra subjacente às influências desse conhecimento institucionalizado advindo das práticas docentes em sala de aula.

Prosseguindo a análise, dos aspectos observados quanto à formação inicial, dos seis entrevistados, apesar de três deles, terem posteriormente cursado uma Licenciatura, percebemos como um grande achado nesta pesquisa, que a maioria dos docentes são oriundos de um ensino médio profissionalizante, ou seja, somada a posteriori com a formação na graduação na área técnica e tecnológica. Isso, de certa forma, influenciou a inserir-se no mercado de trabalho, como também tem contribuído em sua prática docente, pois carrega em sua bagagem formativa um repertório de conhecimentos teóricos, específicos e práticos vivenciados nessa realidade de educação profissionalizante.

Por outro lado, observa-se também que alguns professores sentiram que estava faltando algo a mais e, dessa forma, buscaram complementar sua formação com o principal objetivo de melhorar sua atuação docente. Esta complementação se deu justamente devido sua inserção no mercado de trabalho, conforme relatado aos que na sequência buscaram realizar uma licenciatura, em virtude da sua própria exigência por estar trabalhando com a docência. E, noutro caso, demonstra uma realidade típica nos Institutos, o caso dos engenheiros que viraram docente em virtude da expansão, da necessidade e, pode-se dizer da oportunidade a ele instituída, através da exigência mínima de formação.

[...] por que eu vi que só essa formação Técnica, Tecnológica em si, faltava algo. Observava aquelas formações iniciais de planejamento, formação docente, então... percebi que os pedagogos, o pessoal que tinha licenciatura em si, era diferente, eu não tinha visto isto na faculdade[...], mas eu sabia que fazia diferença, porque ali elas ensinavam a gente, metodologia de projeto, alguma dinâmica, alguma didática que ia colocar isso em prática constantemente[...] (DL1,2015).

[...] um curso de Bacharelado [...] um curso de tecnólogo são cursos que não te preparam na área educacional. Isso, era muito questionado, [...] trabalhando na área de educação. [...]ah! Mas tu és Engenheiro, tu é Bacharel! [...] E, ... dentro desse questionamento [..] eu via necessidade. [...] partir para um curso de licenciatura, aí eu efetivamente resolvi...[...], o engenheiro que virou docente (DL2,2015).

[...] logo que retornei, da minha graduação, começou toda a questão da expansão, [...] e chegou ao meu conhecimento, que engenheiro agrônomo poderia trabalhar como docente. Então eu fiz, pela região. Então... a minha formação não foi para virar docente, eu virei docente, porque, teve expansão, teve a necessidade[...] (DB3,2015).

Observamos a influência que a formação inicial exerce sobre as pessoas e também as influências e interferência do mercado de trabalho ficou claramente explicitada nesses três depoimentos. 
Em relação ao questionamento baseado em um dos principais objetivos desse estudo buscou identificar as percepções dos docentes quanto aos saberes fundamentais para ser um bom professor e quanto a influência da formação pedagógica em sua prática docente. Sobre isso se expressam:

\begin{abstract}
Muito... muito... muito... muito... muito... eu falo assim repetindo várias vezes, porque, hoje eu tenho certeza absoluta disso. A formação pedagógica ela influencia[...] eu? No passado..., a visão que eu tinha era tecnicista...[...] a visão do professor de ontem e hoje é outra coisa... [..] eu também convivo com colegas que não são licenciados e percebemos certa dificuldade dessa compreensão pedagógica...Detalhe!..., infelizmente, até as licenciaturas as vezes é penalizada $[\ldots]$ quando a disciplina é pedagógica, $[\ldots .$.$] relaxa e depois você tem um monte de$ matemáticos, de físicos, com dificuldade tremenda na parte de didática, metodológica que fizeram pouco caso dessas disciplinas pedagógicas(DL1,2015).
\end{abstract}

[...] o exercício da profissão docente [...] se você não souber se relacionar com pessoas fica muito difícil você partir para essa área profissional. Você tem que ter conhecimentos técnicos da tua área, [...] e também, um processo Técnico Pedagógico, esse é o diferencial do curso de Licenciatura, para um curso de Bacharelado. A gente não vê nada do ponto de vista pedagógico[...] trabalhamos com pessoas que vislumbram melhores possibilidades, mesmo que através de uma carreira técnica. E se a gente não tiver atento para cada dia[...] não estar só olhando o conhecimento técnico, mas, está fazendo uma abordagem assim: Como é que estão os nossos alunos? ... estão bem? Se a turma está bem! Se não! Isso..., eu só consegui ver e enxergar um pouquinho através do curso de licenciatura (DL2,2015).

O Depoimento dos professores dos dois perfis confirmou uma das hipóteses que havíamos previsto neste estudo. De que, pelo fato de terem apenas a formação inicial em curso a nível de bacharelado, os professores encontrassem dificuldade em dinamizar suas aulas e fazer esta interação afetiva, partindo da realidade vivida pelos alunos, ou seja, de estar contextualizando melhor o processo ensino-aprendizagem. Todavia, percebe-se que os professores têm consciência dessa dificuldade e, a prática em sala de aula, tem lhe ensinado mudanças de posturas.

[...]quando a gente entra na sala de aula, [...] a gente fica às vezes assustado. E aí, a gente começa a montar um senso de informação, começa a moldar uma forma de transmitir o conhecimento para o aluno, mas, sem as ferramentas... aí, algumas vezes a gente não consegue transmitir a uma boa parte dos alunos àquilo que a gente deseja[...]que é necessário na vida de um profissional[...]. É na questão da metodologia que a gente tem algumas falhas graves, mas, com passar do tempo, a gente vai corrigindo[...] quando a gente entra na sala de aula e ver, que são pessoas, que a gente vai trabalhar e lecionar. Por mais, que a gente não tenha essa sensibilidade, nós somos obrigados a ter.[...] o lado lúdico, isso não existe para a gente. [...]O lúdico estou aprendendo aqui, na instituição [...]utilizar o lúdico, para o aprendizado... isso, são transformações e conhecimentos que o órgão traz para a gente em seminários (DB2,2015). 
[...]um é ter domínio do conteúdo que está ministrando, isso aí, é essencial. [...] ouvimos muito falar, Ah! ... o professor sabe muito, mas não sabe passar. E aí..., [...] que eu estou falando dos bacharéis, de não conseguir passar isso para o aluno. $\mathrm{O}$ outro ponto, que falta também dentro do bacharelado[...] professor entender, que lá dentro da sala de aula, tem gente que está com brigas dentro de casa, tem gente que não se alimentou, tem gente que pode até ter sido estuprado. Então! ..., qual o público que você vai atender? É o adolescente de classe média, que sai de casa, que o pai deixa na porta do colégio? Ou é uma pessoa que tem todos os desgastes sociais possíveis, que vai entrar dentro da sala de aula? Então..., ele tem que ter um bom conhecimento também da parte social, que o aluno pode estar passando (DB3, 2015).

Com base nos depoimentos dos docentes e pelos referenciais teóricos desse estudo, a formação docente influencia no processo ensino-aprendizagem, uma vez que, ao professor, exige-se diferenciados saberes e a questão da gestão da sala de conforme Vasconcellos (2002) compreende basicamente de três grandes dimensões: relacionamento interpessoal, organização da coletividade e o trabalho com o conhecimento. Em sua prática pedagógica, o professor precisa realizar a transposição didática que significa transformar o conhecimento científico obtido em sua graduação, modificando-o, de forma a torná-lo 'ensinável'. Sintetizando, o professor cria relações e condições didáticas para que o aluno aprenda, disso se extrai que apenas o domínio do conteúdo não seja suficiente na prática docente.

Portanto, de maneira geral, o que ficou evidenciado nesses resultados, em outras palavras, que os ensinamentos obtidos na formação inicial, somados com a experiencia de vivência laboral na área de atuação, na formação continuada, e, acrescentando-se a isso a experiência em sala de aula, a interação com os colegas de profissão, estar bem informado e atualizado são saberes de total influência em suas práticas pedagógicas.

Para melhor compreensão e fazendo um cruzamento dos dados, buscou-se a percepção dos alunos em relação ao manejo em sala de aula, das metodologias, enfim, de como veem o planejamento das aulas pelos seus professores. Os resultados demonstraram um descontentamento por parte da maioria dos alunos.

[...] percebemos que alguns professores não têm experiência em sala de aula, sabem o conteúdo, mas não tem dinâmica para explicar (A9,2015).

[...] a maioria dos professores não planejam as aulas, são sempre da mesma forma, só apresentação de slide (A11, 2015).

Noto que a preocupação de trazer coisas novas e que condiz com a nossa realidade somente a Profa. B e o Prof. C. Quanto as outras, noto uma certa enrolação com reuniões e longos textos que nada somam, outros tiram seu material e questões de prova da internet, não tomando o cuidado de substituir pelo menos uma palavra $(\mathrm{A} 7,2015)$. 
Essas falas podem expressar situações específicas percebidas pelos alunos, mas que, de certa forma, foram falhas também admitidas por alguns professores. O que também se evidencia é o fato dos alunos estarem atentos à postura profissional do docente, e a preocupação quanto a forma de ensinar do professor. Em se tratando de metodologias diferenciadas, do ato de planejar que colaboram no processo ensino-aprendizagem e os conduzam ao ato de aprender. Esta realidade observada está condizente com o que a revisão da literatura tem demostrado em relação à questão da Formação e atuação em EPT.

Depreendemos que os professores da EPT, a qual tem como eixo fundante a questão da profissionalização do indivíduo, devem se preocupar não somente nas mais diferentes maneiras de apresentar o conteúdo das disciplinas técnicas, específicas, profissionalizantes, mas também em aproximar-se desse aluno, valorizá-lo como ser humano em construção, compreendendo-o como um cidadão que necessita também de formação sociocultural abrangente proporcionado reestruturação comportamental e uma vida mais digna e solidária.

b) Resultados quanto a trajetória e atuação profissional

$\mathrm{Na}$ intenção de identificar a trajetória e atuação profissional dos docentes buscamos, através dos roteiros pré-estabelecidos, o estabelecimento de outras tantas categorias com o propósito de identificar o tempo de exercício na função de professor, se houve experiência de trabalho na área de formação, antes da atuação como docente e, se esta experiência profissional contribuiu para seu trabalho como professor de EPT.

Nesse eixo temático, também buscamos desvelar alguns aspectos da atuação, os quais tem relação direta com o processo ensino-aprendizagem, tais como: Se além da docência, o professor atua ou atuou em outros cargos administrativos; fatores que dificultam e os que facilitam sua atuação docente. Procuramos também a percepção do professor quanto a oferta de momentos de formação continuada e de reflexão sobre a prática pedagógica oferecida pela instituição, se existe um acompanhamento do desempenho e, por último, buscamos saber, na visão do professor, o que a instituição poderia estar promovendo para aperfeiçoar sua formação docente. Assim, para melhor compreensão dos resultados dos itens elencados neste parágrafo, serão analisados cada aspecto separadamente.

O tempo de docência dos seis professores variam de 5 a 6 anos de exercício da docência na Instituição IFPA-CDA. No entanto, ficou evidenciado, especificamente pelos docentes licenciados, que já assumiram a função docente em outras instituições, mas que não 
eram nos moldes do IF que, trata-se de educação profissionalizante, essas experiências aconteceram em escola regular de educação básica. No geral, variam entre 17 a 21 anos de trabalho como professor e, em um caso apenas, na função de monitor, mas isso é indiferente, pois ambos estão à frente do processo ensino-aprendizagem.

Em relação à experiência profissional de trabalho na área de formação antes da atuação como docente e, se a mesma contribuiu para seu trabalho como professor de EPT. Consideramos um fator altamente positivo, embora perceba que, de forma geral, não tenha sido assim. Mas nesse caso, em específico, dos seis professores pesquisados, quase todos já haviam exercidos profissionalmente trabalhos na área de formação, uns com maior e outros com menor tempo, mas já tinham descido ao "chão de fábrica". E, conforme declarado por eles mesmos, essa experiência profissional foi um requisito muito importante e contribuiu muito para sua atuação enquanto docente no momento de relacionar, exemplificar, contextualizar o conteúdo que está ensinando em uma dimensão ampliada, compartilhando suas experiências práticas daquela profissão.

[...]uma coisa é eu falar de um estágio que eu fiz na faculdade, outra coisa é eu sentar com alunos e levar um projeto que eu fiz na prática... olha, isso aqui eu fiz! [...] tinha tantos andares, tantos metros... essa experiencia de vida, pelo menos nessa parte técnica aqui ela é muito importante porque você traz um contexto prático e aí insere no momento que estiver ministrando as disciplinas teóricas [...]você faz essas ligações[...] faz o aluno pensar[...]...olha esse professor não tem só teoria ele já tem a prática, já passou por isso e...., para a gente enquanto professor dá uma certa segurança de passar aquele conteúdo (DL1,2015).

[...]tive uma experiência antes de trabalhar como docente[...] isso mais tarde, me ajudou a trabalhar dentro do Instituto Federal[...]a ter, um entendimento muito melhor, [...] me ajudou a facilitar esse processo, de ensino- aprendizagem diante dos meus alunos. Claro que, com mais capacitações, com mais estudos para que as aulas não se tornassem meramente conteudistas e ... sim, sempre lembrando da questão nos contextos (DL3,2015).

[...]contribuiu muito, é onde eu vejo que nós professores dessa área, nós conseguimos fazer e dá um diferencial para o aluno, são pequenas coisas que a gente consegue dar um diferencial, consegue esclarecer para ele, o que ele vai fazer, com que ele vai trabalhar, no que ele vai se formar, o que ele vai lidar no dia a dia do trabalho, essa vivencia contribui muito (DB2,2015).

A experiência profissional na área de formação para um professor de ensino profissionalizante se torna um elemento essencial, pois, além de articular o conhecimento acadêmico/técnico com a atividade prática/mercado de trabalho, possibilitará ao professor aquisição de saberes advindos da vivência que serão contextualizados e, no momento da transposição didática, facilitará a compreensão por parte de seus alunos, conforme evidenciado na fala dos docentes. 
Machado (2008), quando se refere ao perfil do profissional docente da educação profissional, faz apontamentos que são semelhantes a alguns apontados pelos docentes, mas, sobretudo, colabora com este estudo quando os complementa, a saber:

O professor de educação profissional deve ser capaz de descrever práticas profissionais (como, por quem e dentro de que condições uma atividade é realizada), de levar em conta o uso que quer desta descrição no processo ensino-aprendizagem (tipo de apropriação e grau de utilização das técnicas) e de estabelecer a diferença entre ensinar práticas e ensinar os saberes sobre estas práticas (construção mais ou menos elaborada, mais ou menos formalizadas destas práticas). Portanto, é desejável que, além da experiência profissional articulada a área de formação específica, saiba trabalhar com as diversidades regionais, políticas, culturais existentes, educar de forma inclusiva, contextualizar o conhecimento tecnológico, explorar situações-problemas, dialogar com diferentes campos de conhecimento $e$ inserir sua prática educativa no contexto social, em todos os seus níveis de abrangência (MACHADO, p.18, 2008, grifo meus).

Ainda nesta categoria de trajetória e atuação profissional este estudo buscou identificar como havia se dado o início do trabalho como professor de EPT se partiu de alguma referência, se houve dificuldade no início da docência. Enfim, se havia recebido formação específica para trabalhar com EPT ao assumir o concurso no IFPA/CDA.

Mesmo os professores que possuem licenciatura, que havia tido experiência docente na educação básica, declararam ter encontrado dificuldade por ser uma experiência em uma modalidade diferenciada de ensino, alunos com aspirações e níveis diferenciados. A dificuldade foi generalizada, todos declararam não terem tido formação específica para atuar nesta modalidade de ensino e, se agravando ainda mais, no caso dos professores, que tinham apenas a formação a nível de bacharelado:

[...]como não tinha nenhuma experiência de Formação nessa área, eu iniciei de forma que achei possível, a disciplina. E tive muitos... muitos... "percalços", a dicção não saía, não tinha posição, eu misturava os temas[...] E apareceram as dificuldades, não teve jeito, os alunos questionando, e eu tentava da melhor maneira possível, passar o conhecimento, mas, sem as metodologias... Houve crítica no início, mas, com o passar do tempo, a gente vai contando com os amigos das outras áreas, como na área da pedagogia[...] fazendo uns ajustes, e foi melhorando aos poucos[...] (DB3,2015).

[...]. Isso é uma das falhas do Instituto Federal [...] temos... licenciados e bacharéis, então, os bacharéis com certeza, eles têm que ter aquela formação da licenciatura. É saber o que é uma didática, é saber o que é uma psicologia de aprendizagem da Educação, saber como que funciona a questão estrutural do ensino[...], então, tudo isso precisa de uma formação e o Instituto peca por esse lado, porque, eu digo assim, falta ainda dentro do Instituto, um desenvolvimento, conversas, reuniões, alguma coisa algum planejamento[...] para não atrapalhar...a questão do desenvolvimento do aluno, no que tange à sua formação (DL3,2015) 
No início da carreira desses profissionais, os mesmos não tiveram nenhum direcionamento e, o fato deles não terem sido formados para atuar na docência, se tornou um fator ainda mais complicador. Percebemos na fala de alguns docentes, os saberes advindos da formação não foram suficientes para que não encontrassem dificuldades no início da carreira docente. Inclusive, constatamos que essa dificuldade foi sentida mais pelos docentes que têm formação apenas a nível de bacharelado e, principalmente, por aqueles que nem sequer tiveram uma experiência de trabalho na área de sua formação.

Para compreender qual seria a melhor formação que o docente deveria ter para atuar na educação profissional, partindo do depoimento dos professores, se vê, claramente, íntima relação com as considerações da pesquisadora Kuenzer (1999) a qual diz que 'a articulação entre o conhecimento científico e conhecimento tácito', ou seja, o conhecimento pedagógico, o da área de conteúdo, articulados entre si e articulados também com a experiência laboral (experiência docente e no exercício profissional na área que se ensina), fazem a diferença no processo didático na Educação Profissional.

Corroborando com essa reflexão, Tardif (2014) define a prática docente a partir de relações que integram diferentes saberes: "Pode-se definir o saber docente como um saber plural, formado pelo amálgama, mais ou menos coerente, de saberes oriundos da formação profissional e de saberes disciplinares, curriculares e experienciais".

Por outro lado, constatamos algo que vai de encontro a tudo que fora mencionado em relação aos saberes ideais na condução do processo ensino-aprendizagem. Um dos professores queixou-se de que, logo de início, ele e outro professor foram lotados em três disciplinas que não dominavam seus conteúdos, como ele mesmo disse: "não tinha na nossa grade curricular da nossa graduação, nem do mestrado". Percebemos, com esse depoimento, que não se trata somente da falta de formação pedagógica aos professores, mas também uma (in) formação da gestão do ensino na Instituição de ofertar (entregar) uma disciplina a quem não possuía os requisitos mínimos, que seriam, no caso, os conhecimentos teóricos e técnicos específicos da área. Nesta linha de análise, fica o questionamento, onde estão os saberes disciplinares, curriculares e experienciais que Tardif (2014) apontou como saber do professor? O depoimento a seguir retrata a dificuldade encontrada pelo professor, diante desta realidade:

[...]. Quando eu entrei [...]estava em plena expansão todos os Institutos Federais, então..., toda expansão, ela também traz um pouco de desorganização na organização institucional, então, eu fiz o meu concurso para a área de Meio Ambiente [...]E na época, o gestor, que eu acredito que foi com as melhores intenções, me convidou para assumir outra área. [...]a área de Agrimensura, junto 
com outro colega [...] então, nem eu, nem o outro professor... tínhamos experiências, mas a vontade de estar no concurso público, e a informação que nós recebemos, é que nós iríamos passar 6 meses[...] fazendo uma capacitação, para atender o curso ...e ...fez nós dois, tomarmos posse. Essa capacitação, não aconteceu. Na semana seguinte, nós estávamos lotados, cada um com três disciplinas, que não tinha na nossa grade curricular da nossa graduação, nem do mestrado [...]foi uma experiência malsucedida...eu tive dificuldade, ...juntando se a parte metodológica que era imatura, ineficiente pela pouca experiência (DB3,2015).

Esta constatação poderia evidenciar expressivos indicativos de um fenômeno mais amplo que, em um primeiro momento, na efervescência da expansão, como disse o professor 'com as melhores intenções', a gestão dos Institutos Federais, tenham primado pela pulverização de campi nas cidades do interior e isso se constata pela quantidade e diversidade de cursos ofertados, mas sem haver uma criteriosa avaliação prévia da compatibilidade do quadro de professores e suas respectivas formações? E, ainda, que o processo acontecia de forma inversa onde primeiro a instituição ofertava turma e depois 'corria atrás' para efetivar, contratar os professores? Analisando o caso em específico, notamos que, com o curso em andamento, as lotações deveriam ser realizadas, com uma certa rapidez para preencher àquela lacuna em sala de aula que, por vez, ocorria-se de ser efetivado professor concursado para uma área, mas, preliminarmente, deveria assumir a docência em outra área.

Deste fato, o essencial deixou de ser prioridade, nem sequer os conhecimentos científicos da área de atuação, o docente, diz claramente que não dispunha. Embora se compreenda que, a efetividade da prática docente não restringe somente a isso, ela é composta de uma ação pedagógica mais ampla e, comungando da mesma ideia de alguns autores, são ações complexas que exigem múltiplos conhecimentos e habilidades, que, neste caso em específico, foram desconsideradas. Santos (2010) descreve o trabalho do professor assim:

\begin{abstract}
A prática do professor é complexa, não apenas por envolver diversas habilidades, como também por exigir que muitas delas sejam utilizadas simultaneamente. $O$ professor ao lecionar um determinado conteúdo não tem apenas que dominar o conhecimento daquele campo, como também saber ensiná-lo, subdividindo-o em tópicos, apresentando exemplos, fazendo analogias, criando atividades etc. Ao lado disto, no momento em que trabalha em classe, terá que saber criar interesses, incentivar os desatentos, fazer perguntas desafiadoras e pertinentes, manter a disciplina, perceber dificuldades de aprendizagem, criar formas alternativas de ensino para os que não estão acompanhando a classe etc. (SANTOS, 2010, p. 9, grifos meus).
\end{abstract}

Além de dominar o conhecimento da área específica em que vai lecionar, o professor deve possuir e ou construir outras habilidades que compreendem o processo educativo, os saberes inerentes da profissão docente. Portanto, não se pode exigir um bom desempenho sem as devidas condições e, a formação inicial se torna um requisito essencial. 
Embora a Instituição não tenha oferecido a capacitação prometida para trabalhar naquela área. No entanto, as dificuldades fizeram com que os docentes, por conta própria, buscassem alternativas de capacitação mesmo num intervalo curto de tempo através de aquisição de cursos pela internet, contato com professores de outros campi que deram suporte da área. Tudo isso só pôde ser realizado, em virtude da infraestrutura disponibilizada na instituição, onde a busca pelo conhecimento tinha que se dá de forma rápida, essa in(formação)se deu através de telefone, através da web, por contatos via e-mail, conversas em tempo real através de Skype, onde os professores dedicaram muitos dias para poder conseguir aprender e ter condições de realizar esta transposição, ou seja, como disse um professor "fazer o link" desse ensinamento para os alunos em sala de aula.

Nota-se uma situação bem pontual, mas tem sido uma prática constante por aqueles que se veem nessa condição e, portanto, buscam alternativas que preencham essas lacunas na formação para melhor exercer o ofício de professor, pois lhes são impostas esta realidade e é como que dissesse 'se vira' cabendo a ele adquirir as competências e habilidades necessárias.

Esta situação nos faz recorrer sobre os desafios e realidades no campo da docência, explorado no segundo capítulo. No caso, tomado para análise, o improviso foi ainda pior, se deu na contramão disso, nem a formação inicial da área técnica o professor dispunha. Mesmo que seja um caso atípico, mas está representando um retrocesso e, talvez, tenha prejudicado o aprendizado dos alunos e deixou o professor numa situação delicada onde o mesmo fez questão de deixar claro para os alunos "que nós não estávamos capacitados para assumir aquilo, que eles se sentissem à vontade, que eu não iria ficar chateado se acontecesse alguma retaliação, não era comigo, era com o sistema (DB3,2015)".

O fenômeno expansão dos Institutos Federais possui uma certa cumplicidade no fato de criar uma expressiva oferta de vagas nesse campo, porém, sem, em um primeiro momento, priorizar políticas de formação desses professores que, em sua grande, maioria - sem considerar o exemplo citado anteriormente, o qual, julga-se ser uma realidade atípica assumem a sala de aula, sem antes ter sequer uma atuação profissional naquela área de formação, muitos irão atuar pela primeira vez e como professor de um futuro profissional técnico, que caracteriza uma contradição gigantesca, sem contar com a ausência de formação em termos de natureza pedagógica. 
c) Fatores que dificultam e os que facilitam a atuação docente na EPT

Nesse aspecto utiliza-se um quadro representando o eixo temático, em relação à atuação docente no IFPA, as categorias de análise foram definidas como fatores positivos e negativos e as subcategorias, são os aspectos correspondentes, que foram considerados pela maioria dos professores sobre as interferências positivas ou não das condições de trabalho para o exercício da docência.

Quadro 4 - Atuação docente no IFPA/CDA (fatores positivos e negativos)

\begin{tabular}{|c|l|l|}
\hline \multicolumn{1}{|c|}{ Eixo Temático } & \multicolumn{1}{|c|}{ Categorias } & \multicolumn{1}{|c|}{ Subcategorias } \\
\hline \multirow{2}{*}{$\begin{array}{l}\text { Atuação docente no } \\
\text { IFPA/CDA }\end{array}$} & $\begin{array}{l}\text { I) Estrutura física } \\
\text { II) Carga horária } \\
\text { III) Quantidade de alunos por sala }\end{array}$ \\
\cline { 2 - 4 } & Fatores & $\begin{array}{l}\text { I) Ausência de Laboratório (aulas práticas) } \\
\text { II) Logística (professor, aluno, livros, materiais) } \\
\text { III) Ausência de complementação pedagógica, } \\
\text { formação contínua e integração docente } \\
\text { IV) Gestão limitada (falta de recursos, burocracia) } \\
\text { V) Acúmulo de cargos (desempenho de múltiplas } \\
\text { funções) }\end{array}$ \\
\hline
\end{tabular}

Os dados revelam três aspectos que foram mais citados, definidos na coluna das subcategorias para análise. Diante dos depoimentos, ficou evidenciada a questão da estrutura física da Instituição, foi o fator que praticamente todos enfatizaram. É preciso caracterizar quais sejam essas estruturas das quais estão falando. Os docentes citaram a questão das instalações físicas, salas amplas climatizadas, mobiliário, auditório e biblioteca.

Outro aspecto foi em relação à carga horária, pelo fato do professor ter um limite mínimo e máximo de carga horária, isso contribui significativamente para seus afazeres pedagógicos, não necessitando permanecer no campus nos três turnos. Outro fator que facilita o processo ensino-aprendizagem é o limite do número de alunos por sala que, dificilmente chega ou excede a 40 (quarenta) alunos. O depoimento do docente expõe sobre essa situação apresentada, a qual considera um fator positivo. No entanto, deixa explícita circunstância contrária, que contradiz em parte o que foi falado do aspecto anterior. 
[...]um privilégio, um quadro docente ter a carga horária de 20 horas, as horas semanais dentro de sala de aula[... [é muito complicado desenvolver algum trabalho de qualidade, quando você está de manhã, à tarde e à noite[...]aí, fico imaginando, como é que ele vai planejar? Como é que ele vai pesquisar? [...] não só pesquisar o conhecimento técnico, é estar complementando aquelas informações: Como é que eu vou melhorar o meu relacionamento com os alunos? Quais são as questões psicológicas, que tenho que avaliar? Como está a minha didática? Os meus processos metodológicos? Será que aquilo que eu apliquei na última aula funcionou ou não? ou tenho que refazer? Então..., tem que ter um momento para isso[...] (DL2,2015).

Acreditamos que a situação de superlotação pode estar evidenciando uma distribuição irregular de carga horária entre os professores e ou ausência de quantidade de professor suficiente para atender a demanda de turmas ofertadas, que acaba obrigando a um só professor de uma dada disciplina específica de sua formação, assumir todas as turmas.

Por outro lado, analisando a categoria de fatores negativos, a questão da ausência de laboratório com materiais para execução de aulas práticas foi um dos aspectos de maior incidência na fala dos professores, os quais se mesclam e revelam princípios explicativos sobre o contexto investigado. Constatamos também, em alguns cursos, a questão de aquisição de equipamentos que se tornaram obsoleto por falta de uso, não que não precisassem, mas por falta de uma formação específica para lidar com tal equipamento. Notamos que esta situação possui íntima relação quando se fez referência a questão da falta de planejamento coletivo entre os professores, que poderiam discutir a priori a viabilidade e a operacionalização.

De uma maneira geral, a questão da logística foi, de certa forma, concentrada nos aspectos de ausência de apoio ao professor na condução do processo ensino-aprendizagem, em relação à ausência e disponibilização de recursos, materiais em sala de aula. Observamos, neste aspecto, que o que realmente foi enfatizado se refere à indicação de que a organização da sala, montagem dos equipamentos, seja realizada por outro servidor, para que o professor não perca tempo com isso.

[...] o apoio Logístico da utilização de materiais. O Datashow já ...montado. [...] se pego Datashow, vou montar, às vezes, passa do horário. [...] os alunos perdem de 10 à 15 minutos com aquilo ali [...] as vezes falta um cabo... caixa de som, [...] Então, essa parte estrutural de logística ainda falta um pouco[...] Na parte de secretaria, eu preparo os Diários, aqui não está automatizado ainda, então, uma hora é um padrão, outra hora é outro[...], o nosso pedagógico agora, até que tá engrenando as coisas, mas ainda estava meio solto isso[...] os que dificultam, eu ainda acho a questão do apoio, apoiar o professor[...] assistente do aluno, que não faz o papel que deveria fazer[...](DL1,2015). 
Notamos que, na percepção de um DL, esta organização dos materiais não deveria ser sua atribuição, até por que se prevê em seu planejamento a utilização de tais recursos, cabe à instituição disponibilizar. Por outro lado, verifica-se que houve uma manifestação quanto ao papel que o outro deixa de executar.

A questão de livros foi citada, no sentido de que a biblioteca precisaria adquirir livros da área e do nível técnico, pois no relato dos professores, dos cursos que possuem livros, a maioria desses está defasada e ou não corresponde ao nível de técnico e sim de graduação.

Em relação aos aspectos da falta de integração e formação dos professores, os relatos demonstram que há uma certa individualização no trabalho docente, pois não há momentos constantes de reflexão da prática com formação e integração entre professores, conforme relatado. Isso contribui para que certos professores, talvez por ausência de uma formação pedagógica, acham que seu papel fica restrito a sala de aula, portanto, não se relaciona com os demais professores para dialogarem sobre o processo educativo. No dizer do professor:

[...] deveríamos começar por ter formações, pelas integrações dos professores, sobre as aulas, infelizmente, ainda existem muitos profissionais que pensam que é, só vim da aula e vai embora. Existem os bons profissionais, mas existem aqueles que precisam refletir um pouco melhor, então, essa questão da integração, da formação continuada ainda é muito falha[...] existe alguns problemas de relacionamento entre docentes e turmas, [...]questão do Inter relacionamento pessoal, [...] é importante a gestão estar olhando com cuidado para isso, isso é um obstáculo, porque acaba tendo um reflexo, e eu não vejo um reflexo positivo. Os alunos estarem saindo dizendo: $\mathrm{O}$ professor A é excelente, o professor B..... Fazendo essa comparativa... então, isso é um trabalho Institucional, primo[...] pela padronização para que os alunos tenham um quadro de professores referencial (DL2,2015).

[...]Cada um dá a sua aula, com seu jeito e sua metodologia, mas, não há um questionamento ou uma reflexão sobre isso... de professores sentarem e refletirem, não acontece (DB2,2015).

Pode-se perceber, pelo depoimento de todos os professores quando questionados se a Instituição oportunizava momentos de formação continuada e de reflexão sobre a prática pedagógica, que o encontro pedagógico, que se realiza no início de cada semestre, é caracterizado por todos como um momento que precisaria ser ampliado para realmente surtir o resultado esperado, pois, da forma esporádica como vem acontecendo, se torna insuficiente.

[...]a gente tira uma semana... alguns dias para o encontro pedagógico[...], eles trazem palestrante[...]umas temáticas. Só que eu acho que esses encontros pedagógicos, teriam que ser, semanal. Eu tinha que dividir minhas angústias com o pedagógico, toda semana, no mínimo[...] (DL1,2015). 
Apesar de serem debatidas temáticas de relevância significativa, de possibilitar a socialização de conhecimentos por palestrantes renomados. Entretanto, notamos que os professores anseiam por um tempo maior com caráter mesmo de formação, principalmente para aqueles professores que não tiveram em sua formação inicial os conhecimentos específicos para assumirem à docência como profissão.

[...]a gente está aguardando da Reitoria essa capacitação, essa complementação pedagógica, para os professores que não tiveram aulas de didática, metodologia de ensino[...] $]$ ntão, a pró-reitoria de ensino, ele já está trabalhando para que o professor tenha um acompanhamento contínuo. E isso hoje não acontece, nós temos os setores que são encarregados, mas nenhum tem uma diretriz para dizer, que vai ter uma formação continuada, vai ter o acompanhamento continuado, com o professor, com a docência, para ver o que está acontecendo, então, hoje não tem na Instituição (DB3,2015).

Eu vejo isso ainda...muito monótono dentro da instituição[...] muitos bacharéis, e os licenciados também[...] A gente tem que ter alguns tipos de capacitações, mas aí, esbarra em alguma questão[...] e aí vai passando o tempo, e a instituição infelizmente não possibilita uma capacitação [...]uma qualificação melhor, para [...] estar na sala com mais segurança, trazer aquilo novo para o aluno (DL3,2015).

A falta de um espaço permanente de reflexão e de planejamento coletivo, interdisciplinar e um acompanhamento mais próximo poderia dar respaldo a muitas situações pontuais, ora apresentadas.

Outra situação constatada foi a questão do poder limitado da gestão pela própria identidade institucional, se tornando um fator prejudicial à questão demasiada de processos burocráticos como licitações para construção, reforma, aquisição de equipamentos e ou materiais que necessitam de parecer da procuradoria da Instituição e essa tem apenas dois procuradores para dar conta de uma demanda enorme originada dos campi. Isso tem provocado uma morosidade no andamento de processos que vai refletir nas atividades do campus, sinalizando talvez que se amplie este número de procuradores e que haja uma melhor redistribuição de demanda para atender em tempo hábil as necessidades, uma vez que o tempo desse trabalho burocrático, em termos judiciais, não atende ao transcurso do calendário escolar, ou seja, o curso tem duração predeterminada, portanto exige-se uma certa celeridade.

As dificuldades maiores, [...]a burocracia. Muitas coisas são planejadas e que às vezes, não são executadas por questões burocráticas, e por questões políticas também[...] Limitações a gente tem, porque estamos muito longe da nossa Reitoria, e isso tem impactado em liberação de verbas, às vezes, até em relação à situações administrativas. Temos alguns problemas jurídicos, do ponto de vista de obras, que começaram e não terminam. E toda obra que não termina dentro de uma Instituição de ensino, ela tem um impacto pra determinados cursos, ou para vários cursos dentro da Instituição[...]questões que deveriam ser agilizadas (DL2,2015). 
Por outro lado, uma questão citada que interfere no trabalho educativo é a questão da rotatividade de professores, permitida através da lei de remoção/redistribuição/qualificação, concedida ao servidor federal, o que não permite realizar e executar um planejamento em longo prazo. $\mathrm{O}$ docente considera um fator negativo, pois segundo ele:

[...]o que mais prejudica é a rotatividade de docente, e quando ele vai, não vem outro docente, vem o código de vaga para o próximo concurso daqui dois anos. Então... isso obriga que a gente pegue disciplinas, que a gente ainda não ministrou, que vai ser a primeira experiência e isso..., é uma dificuldade, carga horária que aumenta [...] (DB3,2015).

Observamos diante do que fora relatado que são situações pontuais que interfere em todo o processo de ensino-aprendizagem da instituição. Por outro lado, apresentam-se situações intrínsecas de um contexto escolar que tem condições de serem amenizadas através de atitudes reflexivas que leve a mudança de realidade.

Através dos depoimentos, ora apresentados, foi acrescido propositadamente o questionamento sobre o que a Instituição poderia estar promovendo para aperfeiçoar a formação docente, visando ao aprimoramento do trabalho desenvolvido em sala de aula e à melhoria do processo ensino- aprendizagem?

Neste momento, verifica-se a confirmação de que a ausência de formação para docência, ou seja, a formação pedagógica tem sido recorrente nos discursos dos professores não somente dos bacharéis, mas também dos licenciados que indicam esta necessidade aos seus pares e almejam por uma capacitação continuada, não só na área pedagógica, mas também na área técnica, para se atualizar e ter melhores condições de oferecer um melhor ensinamento aos alunos.

Vou ser bem direto. O aperfeiçoamento na área pedagógica de ensino, porque sou da área técnica e não tenho esse perfil, e isso contribui para melhorar o ensino aprendizagem. Porque, a gente adquire aqueles conhecimentos das metodologias, como é a relação entre professor e aluno[...] que no meu caso, iria corrigir as deficiências que tenho, embora tenha melhorado (DB2,2015).

[...] a complementação pedagógica ela é importante, eu acho que o primeiro passo para se ter uma atuação continua no ensino. É, igualar todo mundo, colocar todo mundo como professor, como docente licenciado (DB3,2015).

[...]sabemos que temos professores bacharéis e licenciados, sabemos que temos uma evasão alta. Porque não[...]chegar e fazer, com que esses professores possam fazer uma capacitação? [...]. Eu vejo, que a instituição deveria estar engrenada [...]Agora, do jeito que está, não está funcionando, está tudo fragmentado. [...] a sugestão que eu dou é, que faça diagnósticos, ... escutando o aluno, escutando as angústias do professor, e o quê que eles têm para fazer? [...] as vezes passa aquele negócio ali 
para a sala de aula..., ele faz de um jeito que é pra fazer, do jeito dele, aí, fica aquele negócio que não ganha o aluno, não ganha o professor, não ganha a instituição (DL3,2015).

A formação permanente[...] através de cursos, trazendo gente capacitada de diversas áreas[...]de Inter relacionamento. Na parte de Ética profissional, a questão técnica pedagógica mesmo, de didática[...]curso de Psicologia também, a psicologia explica muito das coisas que acontece dentro da sala de aula[...] não são todos os docentes, mas, eu diria que é importante um ciclo permanente que a gente deveria estar se atualizando (DL2, 2015).

Entendemos que todos esses depoimentos têm trazido representações que permeiam o cotidiano desses docentes, os quais evidenciam aspectos bem peculiares e, de certa forma, evidenciam as possíveis respostas ao questionamento inicial de estar analisando a influência da formação do professor de EPT, no processo ensino-aprendizagem dos alunos dos cursos técnicos subsequentes. Logo, evidencia-se que a formação para a docência tem influência, na medida em que além de capacitá-lo com o conhecimento específico da área, os capacita para atuar como docentes, com os conhecimentos próprios da docência, de conhecimentos didáticos, metodologias apropriadas que favoreçam o processo ensino-aprendizagem e também conhecimentos da área de psicologia educacional que lhes dê suporte para realizar a docência, mediar os conflitos e sanar as dificuldades de aprendizagem de forma mais efetiva.

Para finalizar este eixo temático em relação à atuação docente no IFPA, buscou-se compreender se o docente atuou ou se atua em outros cargos administrativos na instituição, além da docência, e qual seria a percepção dele sobre o comprometimento da qualidade em virtude do desempenho de múltiplas funções.

[...]Claro que compromete, se tivesse só disponibilidade para desenvolver essas atividades, era outra coisa. Mas, infelizmente, isso não vem acontecendo e acaba comprometendo a qualidade do ensino[...] (DB3,2015).

Já tive, algumas coordenações e direções[...] dava pra conciliar, mas não com a mesma qualidade do que quando você está só na docência. Eu acho que se alguém falar assim, não..! é tranquilo!... não é... Na docência..., você está livre só pra aquilo ali, para atender aluno, pra pesquisar livros[...] (DL1,2015)

[...]. Uma pessoa só, fazendo duas, três atividades, acho que perda sempre deve ocorrer. Assim, eu acho que faz o básico, solicita o documento e tu faz, mas com muitas atribuições, acaba não passando disso, não conseguindo reestruturar o local (DB1,2015).

[...]é preciso ter um envolvimento, [...] acho que, estamos anos luz, ainda... engessado, dentro da questão desse processo de ensino e de aprendizagem, e isso compromete também, a questão de como esse aluno vai sair. [...]tento fazer da medida do possível, dentro dos cargos, a engrenagem funcionar, mas [...]dentro desse contexto, tem peças que travam o processo, e isso é difícil, pessoas que são resistentes, que não gostam de fazer, que atrapalham[...] (DL3,2015). 
Além da docência, todos os professores desta pesquisa exercem outros cargos administrativos, como chefia, coordenações de curso, representação da categoria e ainda participação em comissões e colegiados. Portanto, identifica-se nos próprios depoimentos que isso acaba comprometendo as funções em sala de aula e também na gestão. As circunstâncias indicam que, as atividades acabam sendo realizadas no formato 'apagando fogo', pois, tanto um, quanto o outro, para que realmente haja produtividade e não ficar só no básico, necessitam maior envolvimento e isso, com certeza, demanda um tempo maior.

d) Resultados quanto as Práticas Pedagógicas no ensino técnico subsequente

Esta temática exigiu a elaboração de subtítulos, para melhor compreensão dos dados. A partir dos subtítulos, criou-se a priori, categorias e roteiros pré-estabelecidos que designassem os indicadores que levariam o professor a discorrer sobre assuntos delineados precocemente e que seriam pertinentes à pesquisa.

Partindo do que Franco (2012) define como categorias criadas a priori “[...] categorias e seus respectivos indicadores são predeterminados em função da busca a uma resposta específica do investigador". Esse procedimento contribuiu para uma reflexão ampla da prática docente, sem a pretensão de julgamento do trabalho realizado, apenas produção de inferências críticas e reflexivas do cotidiano do professor de EPT em sala de aula. Esse momento, tanto para a pesquisadora, quanto para o professor entrevistado se deu num clima de diálogo tranquilo e que suscitaram várias reflexões para ambas as partes.

Nesse sentido, fez-se categorização mais ampla com seus respectivos indicadores que se transformaram em formas de questionamentos de aspectos relacionados à docência. Os resultados serão apresentados sequencialmente a partir de cada temática genérica.

Planejamento Didático

Neste aspecto, os resultados e análises serão em referência ao que fora abordado de forma ampla sobre o processo de planejamento do ensino-aprendizagem e suas correlações. Nesse propósito, elaboraram-se os aspectos indicadores que serviram de um sequenciamento e ordenamento melhor de cada processo explorado para esse estudo. 
a) Planejamento do ensino e o planejamento da aula

Em relação ao aspecto mais formal do planejamento, se faz pertinente esclarecer que na Instituição pesquisada ficou estabelecido através de consenso entre os professores em um dos primeiros encontros pedagógicos realizados na Instituição, que a exigência se daria apenas numa dimensão macro que seria o Planejamento de Ensino e ou Plano de Ensino como um registro previsível, porém flexível, de um projeto de trabalho docente que, resumidamente, se refere ao que o professor vai ensinar e o como vai ensinar dentro de um período de duração da disciplina. Obviamente apontando a possibilidade de haver algumas modificações, conforme referendado por Tardif e Lessard:

\begin{abstract}
[...] o Planejamento não passa de um plano, um mapa geográfico do ensino; portanto, é normal que, em contato com o território real do trabalho, esse mapa seja modificado, especificado, adaptado. Em geral, os professores por profissão, modificam seu planejamento, se esforçarão por respeitar suas linhas gerais, os objetivos mais importantes [...] eles conservam, assim, o essencial, a configuração básica, mas podem mexer nos prazos, deslocando conteúdo para uma outra aula, abandonando objetivos considerados secundários [...] diferentes fatores entram aqui em consideração nesse trabalho de ajuste e de transformação curricular (TARDIF \& LESSARD, 2011 p. 2014).
\end{abstract}

Vasconcellos (2012) prefere usar o termo projeto de ensino-aprendizagem "em função do significado mais vivo, dinâmico e, potencialmente, mobilizador”. E porque não só projeto de ensino? "Antes de mais nada, porque ensino e aprendizagem são conceitos essencialmente relacionais e dialéticos" e complementa citando Veiga (1997 p.139) porque "o ensino (magistério) não existe por si mesmo, mas na relação com a aprendizagem (estudo). [...] o que existe entre o ensino e a aprendizagem é uma relação de 'dependência' ontológica".

Analisando a estrutura do Planejamento de Ensino, que ficou institucionalizado, os professores elaboram o referido documento, basicamente, com as seguintes informações: identificação do professor, disciplina, curso, duração, carga horária, ementa, justificativa, objetivo geral e específicos e um quadro em que o professor projeta seu plano de ação docente referente ao conteúdo, procedimentos metodológicos, ou seja, as estratégias de ensino, material e recursos didáticos e como se dará o processo de avaliação da aprendizagem para àquele conteúdo/disciplina em específico que estará sob sua responsabilidade e, por último, discorre sobre as referências bibliográficas que utilizará para ensinar o previsto. 
Importante esclarecer também que a gestão de ensino apenas normatizou a exigência para que o professor elabore um planejamento parcial antes de iniciar às aulas e entregue às coordenações de curso e de ensino assegurando uma prévia das atividades a serem desenvolvidas evitando ações improvisadas.

Entretanto, sabe-se que o planejamento didático se dá de forma contínua e processual e não se trata de atender à exigência da gestão de ensino, mas o ato de planejar o ensino é uma necessidade intrínseca do trabalho do professor.

Além disso, a elaboração do Planejamento de ensino não elimina a preparação de cada aula. Subentende-se que, para ministrar sua aula diária o professor tenha que fazer o planejamento da aula que, neste caso, é bem mais específico e detalhado.

Sobre o qual, recorre-se a definição de plano de aula feita por Vasconcellos (2012) “[...] é a proposta de trabalho do professor para uma determinada aula ou conjunto de aulas. Corresponde ao nível de maior detalhamento e objetividade do processo de planejamento didático. É a orientação para o que fazer cotidiano".

Nesse sentido, dirigiu-se o questionamento ao professor se ele compartilhava com seus alunos este planejamento mais geral daquela disciplina e também o que fora planejado para aquela aula para que o mesmo obtivesse uma visão geral e detalhada de como aconteceria seu percurso formativo e pudesse colaborar em algum momento propondo alguma modificação em função da sua realidade.

Percebemos que esta atividade está sendo realizada, porém constata situações diversas quando explicam como isso tem acontecido. O DL, inclusive, diz fazer questão de dialogar, principalmente com os alunos sobre as aulas práticas e visitas técnicas previstas para que os mesmos possam também planejar-se para participação. Porém, em outros casos, a utilização deste procedimento tem tido um caráter meio que para cumprimento de um ritual de apresentação inicial do professor em sala de aula, onde o professor, prioritariamente, faz o enfoque, voltado somente para exposição da ementa, leitura dos objetivos e, em poucos casos, discute o plano na sua totalidade. Entretanto, ressaltaram que, de início, houvera resistências principalmente por parte dos DB. A fala do DB2 retrata muito bem essa situação:

[...] toda pedagogia falava que você tem que entrar em sala de aula e colocar o plano de ensino, mas, nós não tínhamos esse costume, essa é a verdade, quem é da área técnica, não tem esse costume, mas aos poucos, a equipe foi acostumando e realmente a gente coloca agora, o plano de ensino, explica o objetivo da aula, objetivo da disciplina. Hoje, já é feito! ... Só no início... porque não tinha essa formação (DB2,2015, grifo nosso). 
O que fica evidenciado nesse depoimento, que esse trabalho tem sido realizado por uma exigência da equipe da diretoria de ensino. Todavia, percebemos que o próprio verbo utilizado 'coloca', já descaracteriza uma intencionalidade pedagógica em partilhar com seus alunos o que foi previamente planejado para aquela disciplina, nem tampouco, oportuniza a participação do aluno no redirecionamento de alguma atividade proposta.

Sabe-se da importância fundamental para o ensino-aprendizagem, a forma como o docente estabelece esse contato inicial na discussão dos conteúdos a serem trabalhados e aprendidos pelos alunos, pois neste clima de relacionamento interpessoal, baseado no diálogo, com certeza contribuirá para que o aluno se sinta respeitado, estimulado e ganhe segurança em expressar seu histórico de vida, seu conhecimento prévio de determinado assunto, até mesmo suas opiniões, suas dúvidas e o que está buscando aprender.

Enfatiza-se que, em apenas dois dos casos, os docentes deixaram claro que tem essa postura democrática em sala e, em algumas ocasiões, tem alterado seus planos em virtude das contribuições dos alunos, principalmente com sugestões de palestras, visitas técnicas e, sobre o melhor período para realizá-los dentro de suas possibilidades. Contudo, notam-se nas entrelinhas, as restrições que o sistema impõe em relação aos recursos necessários.

Por outro lado, observa-se que um dos aspectos que deixa de ser abordado pelos professores, ao menos não nos foi relatado, se refere em trabalhar dialeticamente, o perfil profissional desenhado no PPC, após conclusão daquele curso em específico, pois a partir dessa informação discutida com os alunos, dos conhecimentos, saberes, competências profissionais e pessoais requeridas àquela sua futura profissão técnica, o mesmo poderá refletir e, com certeza, se sentirá atraído e haverá maior envolvimento nas atividades propostas, bem como, o próprio aluno poderá propor outras alternativas mais palpáveis para apreensão daquele ofício que, talvez, não tenha o professor considerado em seu planejamento inicial. Enfim, oportuniza a participação do aluno nos caminhos a trilhar para seu processo de construção do conhecimento.

Diante desta relação dialética, pedagogicamente, sabe-se que o aluno passa a ter maior empenho e se predispõe a aprender, seria aquilo que David Paul Ausubel (1918-2008) definiu em sua teoria da aprendizagem significativa, da qual se compreende que a aprendizagem só se torna eficiente quando interfere na estrutura cognitiva do indivíduo, logo, há uma interação dos conhecimentos prévios com o conhecimento novo, propiciando uma aprendizagem profunda. Caso contrário, o ensino passa a ser encarado como uma imposição externa e recai, consequentemente, a uma apreensão mecânica, com informações superficiais, 
não reflexivas que levam a memorizações que num curto espaço de tempo serão automaticamente esquecidas.

Nesse contexto, entendemos que ao professor é atribuída a missão de ensinar e, para isso, inevitavelmente, o ofício da docência, em sua dimensão real de existência, necessita de mecanismos didáticos diferenciados que desafiem os alunos, que instiguem, que promovam o aprendizado, os quais são previstos em seu planejamento. Este planejamento inicial pode ser reformulado, quando em contato com a realidade concreta, perceba a necessidade. Portanto, ao professor, cabe assumir-se a obrigação de fazer a mediação, apresentando as diversas possibilidades para que, de fato e de direito, estabeleça uma relação neste processo ensinoaprendizagem de forma significativa com a participação de todos.

Nessa perspectiva, as reflexões que Libâneo (1991) apud Rios (2011) faz compreender essa relação do ensino como objeto da didática e como uma prática social, pois, segundo ele:

\footnotetext{
Por intermédio do gesto de ensinar, o professor na relação com os alunos, proporciona a eles, num exercício de mediação, o encontro com a realidade, considerando o saber que já possuem e procurando articulá-lo a novos saberes e práticas. Possibilita aos alunos a formação e o desenvolvimento de capacidades e habilidades cognitivas e operativas (Libâneo, 1991:100) e, com isso, estimula-os a posicionar-se criticamente diante do instituído, transformando-o, se necessário (RIOS, 2010, p.52, grifo meus).
}

Entendemos que a infraestrutura física e de materiais de ensino disponibilizada pela instituição, indiscutivelmente, tem sua necessidade nas ações pedagógicas, mas, essencialmente, a postura profissional do docente estabelecida na relação afetiva e dialógica com seus alunos, na condução do seu trabalho docente, faz toda diferença para que se alcance maior êxito na educação emancipatória que se predispõe a realizar. Logo, à docência precisa estar ancorada em um processo permanente de reflexão sobre a ação garantindo uma intervenção prática e racional.

b) Planejamento coletivo e interdisciplinaridade

Sobre esse aspecto, a intensão da pesquisa se pautou em obter informações dos docentes, quanto à questão do planejamento em conjunto com os professores que lecionam no mesmo curso ou no mesmo eixo tecnológico, propiciando uma interação e integração dos 
vários conteúdos e ou práticas a serem desenvolvidas na condução do processo de ensinoaprendizagem.

Por processo interdisciplinar, entendemos que não se trata de uma justaposição ou junção de disciplinas e ou de professores, onde cada um entra em sala e faz o seu papel, mas no sentido de realização de um planejamento pensado e organizado coletivamente com contribuições significativas das várias áreas do conhecimento, das diferentes disciplinas do curso e ou do eixo tecnológico, que se integram reciprocamente e se complementam em torno de um objetivo comum, ou seja, possibilitar sustentação, explicação, ampliação dos saberes profissionais desenvolvidos na formação.

Rios (2010) colabora com a compreensão dizendo que:

Existe interdisciplinaridade quando se trabalha verdadeiramente de um diálogo, ou de uma parceria, que se constitui exatamente na diferença, na especificidade da ação de grupos ou indivíduos que querem alcançar objetivos comuns, que 'jogam' em posições diferentes num mesmo 'time'. É preciso ter muita clareza no tipo de contribuição que cada grupo pode trazer, na especificidade dessa contribuição [...] (RIOS,2010 p. 58).

Portanto, para o cidadão que se quer formar neste novo tempo, àquela formação numa perspectiva disciplinar, fragmentada, sem estabelecer interação das ações e significações, com certeza, comprometerá a formação cidadã, pois limita sua capacidade de intervenção na realidade e sua postura com seus semelhantes.

No sentido da didática, a interdisciplinaridade, significa “[...] reafirmar o objetivo de uma formação que levem em conta todas as capacidades a serem desenvolvidas nos alunos/aprendizes e que as mobilize de maneira crítica e criadora" (RIOS, 2010, p. 60).

Analisando os depoimentos dos docentes sobre este aspecto, evidencia-se que este trabalho interdisciplinar tem acontecido esporadicamente, sem um aprofundamento da sua natureza de ser, sem uma sequência sistematizada e constante.

Em alguns momentos, verificamos exemplos de ações esporádicas que não correspondiam enfaticamente à questão da interdisciplinaridade, da ação pensada conjuntamente, regada de propósitos comuns, ou seja, planejar uma atividade com uma objetividade e rigor pedagógico, mas se referiam a reunião de alguns docentes para divisão de papéis e ou função que desempenharia num dado projeto. Como se verifica, no depoimento do docente DB1, se referindo que na matriz curricular possui uma disciplina denominada de Projeto integrador. Nos dizeres desse docente, os professores desse curso [...] junta todos os conteúdos concomitantes, [...] aí, a gente faz uma única atividade, [...] todos os professores 
são envolvidos. Cada um, na sua disciplina que ministrou e faz alguma atividade, algum evento, alguma viagem técnica[...] (DB1,2015).

Fazendo um cruzamento das informações, constatamos que em quase todos os PPCs quando se referem à organização curricular enfatizam para que haja metodologias pautadas na interdisciplinaridade, dando condições para que o aluno vivencie o trabalho em equipe e desenvolva habilidades e competências inerentes ao exercício profissional. Os depoimentos dos professores sinalizam a realidade encontrada:

[...]. Mas pena que é pouco. Algumas coisas são assim... Dei meu conteúdo, dei a minha parte, dei a minha disciplina, pronto. Fragmentei, se ele vai casar isso com outra, aí, já não me interessa, que a minha disciplina foi dada. Mais ou menos assim. Não estou falando que é uma visão minha, mas no geral, é mais ou menos assim (DL1,2015, grifos meus).

[...]. Às vezes, é feito de improviso em relação à visita técnica. Alguém propõe que é feito ali, mas, não foi planejado lá no início, como deveria ser. Eu vejo ainda um planejamento, assim, uma coisa que precisa ser muito melhorado dentro dos Institutos, principalmente aqui no nosso Campus (DL2,2015, grifos meus).

[...]Devido à grande rotação de professores, não tem como você fazer um planejamento longo, com todas as disciplinas [...] por isso eu me pergunto: existe a interdisciplinaridade? Existe. E pergunto mais: ela é obrigatória hoje no Campus? Eu digo que não, pela nossa rotatividade de professores, então, todo semestre tem um momento de semana de planejamento, que conhecemos como semana pedagógica. [...], mas nem sempre ele é cumprido pelas adversidades geográficas que a gente tem. O professor não está no momento, [...] já é outro colega, então eu acho, que quando se consolidar um corpo docente, a interdisciplinaridade vai ficar mais fácil, porque você vai saber com quem você vai estar trabalhando (DB3,2015, grifos meus).

Percebemos uma boa intencionalidade da Instituição como um todo, em prever na organização curricular dos cursos a possibilidade desse trabalho partilhado, coletivo, contextualizado. Entretanto, notamos que ainda há pouca efetividade e, talvez, se faz compreender pela ausência de formação para a docência e também por não haver espaços permanentes e constantes de formação continuada, planejamento e suporte pedagógico na/para a ação docente.

c) Seleção do material didático e estratégias de ensino

Propôs-se com esses indicadores, buscar informações do professor qual seria o critério para iniciar seu planejamento, selecionar o material didático, se possuía algum método específico e ou estratégias de ensino para ministrar os conteúdos, se o mesmo elaborava 
material para os alunos como apostila e, de que forma o aluno acompanhava o conteúdo trabalhado no momento de formação.

Nesse contexto, todos os professores destacaram que utilizam das orientações contidas no PPC para elaborar seu planejamento, prioritariamente, em relação a ementa e referencial bibliográfico. Observamos algumas críticas em relação a estes dois aspectos nos PPCs, pois alguns cursos apresentam estarem desatualizados ou até mesmo com indicações de referencial bibliográfico desconhecido e ou em nível superior ao técnico e também pelo acervo bibliotecário do Campus não dispor de tais livros, fazendo-os utilizar-se de outras fontes de referencial bibliográfico que os auxiliem.

Quanto ao questionamento, se o professor elaborava algum material apostilado para repassar aos alunos, observamos que a maioria dos docentes não elabora e acredita que os alunos devam ir buscar, pois abre um leque de possibilidade ao aluno, como, por exemplo, a utilização da internet para reforçar seu aprendizado, como observado na fala do DL2 “[...] acho fundamental, que os nossos alunos principalmente aqueles que a gente pretende jogar no mercado, sejam pessoas reflexíveis, pensem, e não peguem coisas fechadas”. Outros dizem utilizar-se de textos, artigos que são disponibilizados em reprografias, mas nem sempre o aluno possui condições financeiras de arcar com o volume de fotocópias que lhe é exigido em todas as disciplinas do curso. Outras formas de compartilhamento de materiais são através da web, por exemplo, os alunos da disciplina de informática utilizam muito o dropbox para compartilhar arquivos com textos e vídeos entre eles e o docente. Os demais professores compartilham os slides utilizados na aula através de e-mail da turma e também o disponibilizam através de pendrive a quem possa interessar.

No entanto, observamos também, em relação a esse aspecto, que houve um contraponto, pois há quem também defende a questão da necessidade do livro didático para o curso técnico e justifica seu posicionamento dizendo que:

[...] é muito difícil dentro do Instituto a questão dos livros didáticos[...]não temos livros para saneamento, nós não temos livros para Agrimensura [...], temos uma biblioteca que ela ainda é muito... [...]diminuta para a questão de livros...[...] ainda está tentando, catalogando, mandando... [..]isso ainda é muito burocrático [...], mas, nessa questão de não ter o livro didático, o que é que você faz? Às vezes, você planeja as suas aulas em cima de apostilas, [...]fica difícil do aluno comprar apostila, tirar cópias. [...] os livros didáticos [...]poderiam estar ali, para auxiliar melhor a aula, e o professor ele se vê nessa ida, de fazer o material, passar para o aluno, tirar as cópias, acompanhar as suas aulas na apostila, aquele negócio todo...[...] (DL3,2015) 
Analisando o depoimento do professor, percebemos que não é somente o fato de alguns alunos não possuírem condições financeira de adquirir a fotocópia, mas o professor deixa escapar algumas evidências que "essa preparação de material para o aluno", agrega mais um trabalho a ele, de separar material, elaborar apostila, disponibilizar em reprografia e isso talvez faça com que o mesmo defenda que nos IF seja disponibilizado o livro didático que ajude tanto aluno quanto ao professor na condução do processo ensino-aprendizagem.

Percebemos uma postura um quanto radical do professor e nota-se de um DL, pois a elaboração de material para as aulas é de competência do professor. Este planejamento deve partir dele, não generalizando, mas em se tratando de livro didático o que se vê na grande maioria de escolas públicas e até mesmo privadas que utilizam livros didáticos, os ensinamentos, infelizmente, se limitarem a esse recurso.

Por outro lado, os livros didáticos nem sempre atendem a uma necessidade específica, uma vez que o poder público adquire em grande quantidade para disponibilizar a uma demanda maior de alunos por este país a fora. Além do que, em se tratando da diversidade de cursos técnicos, talvez não seja uma realidade tão próxima, mas nada impede que sejam sinalizadas esta indicação e suscite estudos sobre o uso do livro didático.

Ademais, a apostila elaborada pelo professor contém uma seleção intencional de textos, ilustrações que trarão significados àquele conteúdo a ser trabalhado dentro dos conhecimentos, competências e habilidades traçadas para àquela profissão. No entanto, se torna evidente que, ao professor, cabe utilizar-se de uma solução para que possa assegurar que o que fora proposto no PPC daquela profissão seja alcançado de forma física por todos os alunos, independentemente de sua condição social e econômica.

Quanto à questão de estratégias de ensino, percebemos a predominância das aulas expositivas através de apresentação em slides, seminários, exercícios variados e, em algum momento, muitos raros, utiliza-se a aula prática e ou visita técnica. Realidade também enfatizada na fala dos alunos.

Trata-se de realizar alguns apontamentos sobre as situações apreendida até então na pesquisa. Nesta sociedade internacionalizada, da qual se vive a era da informatização, sabe-se que a escola não é o único lugar em que o aluno aprende, portanto, diferentemente da educação informal, na escola a aprendizagem passa a ser concebida dentro de uma estruturação organizada, dentro de um planejamento intencional e é nesta hora que o papel do professor faz toda a diferença quando se utiliza de meios, métodos, recursos e estratégias 
diversificadas com o propósito de fazer a mediação para que o aluno tenha prazer em construir seu próprio conhecimento.

Outrossim, a construção do conhecimento perpassa sobremaneira pela seleção e organização desses recursos didáticos utilizados pelo professor para que o aluno tenha uma referência e estabeleça uma relação partindo do real, do concreto e obtenha uma aprendizagem ancorada em reflexões de forma significativa. A fala coerente de um dos docentes traduz bem essa concepção "[...] se o aluno não encontrar significado palpável para aquilo ali, eu penso assim..., que ele vai aprender, mais por uma obrigação de nota [...] já me vi livre desse conteúdo[...]" (DL1, 2015).

\section{d) Aulas Práticas e Visitas Técnicas}

Objetivamos, diante desse tema indicador direcionado ao professor, saber se ele conseguia realizar a articulação da teoria com a prática e se estava acontecendo, tanto as aulas práticas, quanto as visitas técnicas e sobre a importância de ambas no processo ensinoaprendizagem dos cursos técnicos de nível médio.

Partindo do princípio de que, para um bom aprendizado é necessário haver esta articulação teoria e prática, principalmente em se tratando de formar profissionais técnicos com condições reais de atuação no mundo do trabalho, fica evidente que, tanto a aula prática, quanto a visita técnica, são recursos metodológicos de fundamental importância dentro desse contexto da Educação Profissionalizante, pois possibilita ao docente oportunizar ao aluno, dentro do contexto empírico profissional, a contextualização do conhecimento apreendido e sua aplicabilidade dando maior segurança e sentido à formação técnica recebida.

Nesta perspectiva, percebe-se que boa parte dos DL declaram, salvo alguns impedimentos, que tem procurado estabelecer articulação do conhecimento teórico com alguma atividade prática para facilitar o entendimento pelos alunos e colocá-los em contextos reais de trabalho, oportunizando o contato com o saber fazer, conforme se vê nos depoimentos a seguir:

[...]a gente consegue, porque a proposta do Instituto é, para ele atuar no mercado profissional e o mercado profissional, sem o conhecimento da prática, fica muito difícil[...] (DL2,2015).

[...]com a aula teórica e prática, ele já vai aprender, não só aquela parte técnica, ele vai aprender o contexto [...] tem que deixar isso claro para o aluno, que ele possa pensar, ele possa dar o ponto de vista, que ele possa estar seguro, para encarar o mercado de trabalho (DL3,2015). 
Nesse sentido, a percepção do DL, tem um grande diferencial no processo ensinoaprendizagem, corroborando com esta análise Imbernón (2010) faz a seguinte reflexão sobre como deve agir o professor nessa sociedade globalizada: “[...] embora seja importante saber o que deve fazer e como, também é importante saber por que deve fazê-lo[...]”.

Nesse contexto, percebemos que no dizer do professor "tem que deixar isso claro para o aluno, que ele possa pensar", isso faz parte de um planejamento prévio do objetivo real daquela atividade prática, fazendo com que o aluno não apenas visualize, mas vivencie na prática e, principalmente, que ele pense, que passe a ter uma postura reflexiva diante daquela atividade proposta que resultará em conhecimento profissionalizado.

Inclusive nesta mesma linha de percepção, outro docente enfatiza que, em se tratando de curso técnico, procura trabalhar a partir de uma dinâmica diferenciada onde, uma hora parte da teoria para a prática, outra hora aplica-se o inverso, para que da prática o aluno extraia a teoria. Comenta-se que tem dado resultados positivos, pois, segundo o docente, os alunos têm expressado que com atividades práticas, os alunos aumentam o interesse e a motivação e, com certeza, apreendem mais. Sobre esse aspecto, o depoimento do docente, reproduz com grande entusiasmo o que acontece quando propõe tal atividade:

[...]oh, pessoal...! Vamos para prática! ... chega os alunos fica com aquele brilho no olhar. [...] A gente percebe que é diferente. [...] é como se o teórico ganhasse vida, ganhasse um significado para eles [...]. Então! Tem muito conhecimento solto sem vida parece que... há! Vai passar porque tem que fazer uma prova. Mas não é assim..., tem que ter sentido às coisas (DL1,2015).

Por outro lado, verifica-se que, apesar de existir docente que encontre mais facilidade em conseguir realizar as aulas práticas, talvez em virtude de uma série de fatores, entre eles o da própria caracterização do curso e dos meios utilizáveis para tal finalidade, também se encontra docentes e, verifica se que o perfil dos DB foi os que mais evidenciaram a dificuldade em estabelecer a relação teoria prática, por diversos fatores. Entretanto, embora, não tenha conseguido muito êxito, mas tenha levado na medida do possível, conforme o depoimento que se segue:

Sempre parto do princípio, por ser um curso técnico, tem que ter muita prática. [...], mas nós, não temos ainda a estrutura, esses meios e recursos que nos possibilitem a isso, então..., dentro da nossa possibilidade, a gente tenta levar a prática da melhor forma que der [...] a gente faz o possível, mas sabe, que não é o ideal, por falta de recursos e isso prejudica muito (DB1,2015). 
Em relação a visitas técnicas, percebemos que a Instituição também ainda precisa se articular melhor para realização desta atividade, principalmente para munir-se de condições de atendimento a todos os cursos técnicos ofertados, uma vez que, a grande maioria dos professores ponderou a falta de estímulo para realização desta atividade pela indisponibilidade de recursos financeiros quando solicitados e ou falta de conhecimento da sua real necessidade. O depoimento na sequência expressa como o docente vê esta situação na Instituição:

\begin{abstract}
Infelizmente, a Instituição não nos dá apoio algum [...]e o que precisava para uma visita técnica, é o veículo, o óleo diesel e o motorista. A gestão da Instituição, não vê isso como prioridade, acha que é "TUR", turismo. [...]isso prejudica as visitas, então, são feitas poucas visitas técnicas. Muito pouca. É feito visita porque os alunos pedem, e o professor se envolve e teima e briga até conseguir, aquele veículo, naquele período, naquele determinado momento. Então, não há o planejamento e eu também não vejo interesse. Agora, em relação a prática de executar, aí, a gestão falha $100 \%$, porque, até hoje nós não temos Laboratório, então, é uma lacuna no aprendizado dos alunos e a gente sabe disso (DB2,2015, grifos meus).
\end{abstract}

A metáfora de Jaques Busquet o qual descreveu sobre o "curso de preparação de nadadores", no qual faz uma tradução irônica do processo de formação inicial de professores, sobretudo em relação à articulação entre a teoria e a prática no processo de formação, parece ter algo semelhante com a formação dos alunos nos dizeres grifados acima e emerge uma reflexão para ambas as situações:

\begin{abstract}
Imagine uma escola de natação que se dedicasse um ano a ensinar anatomia e fisiologia da natação, psicologia do nadador, química da água e formação dos oceanos, custo unitário das piscinas por usuários, sociologia da natação (natação e classes sociais), antropologia da natação (o homem e a água), e, claro, a história mundial da natação, dos egípcios aos nossos dias. Tudo isto, evidentemente, à base de cursos magistrais, livros e quadros, mas sem água. Numa segunda etapa, os alunos nadadores seriam levados a observar, durante alguns meses, outros nadadores experientes. E depois desta sólida preparação, seriam lançados ao mar, em águas bem profundas, num dia de temporal. (BUSQUET apud PEREIRA, 1999, p.112)
\end{abstract}

Embora se perceba pelos depoimentos de alguns docentes que em alguns cursos tenha estabelecido uma relação dialógica do conteúdo com a prática, da realização de visitas técnicas, obviamente dentro de suas limitações, mas, em sentido contrário, em outros, percebemos que pela ausência de condições mínimas de infraestrutura, de laboratório didático, ferramentas próprias, por falta de recursos financeiros e ou planejamento, essa relação ou até a aula prática em si, tem deixado de ser realizada. Na própria percepção dos docentes, essa ausência resulta em uma lacuna no aprendizado do futuro profissional disponibilizado no mercado do trabalho. Sem dúvida, isso é fato e merece ser reparado. 
Diante da realidade apresentada, consideramos uma situação recorrente no qual os depoimentos dos professores vão de encontro com o resultado da pesquisa realizada sobre a "Gestão dos egressos" no ano de 2012, referenciada na parte introdutória dessa dissertação, onde os resultados revelaram que o ensino ficou a desejar pela ausência de aulas práticas, de laboratórios, visitas técnicas e equipamentos específicos da área técnica entre outros.

Percebemos que a prática educativa, embora alguns docentes disseram realizar, mas no geral, há um entrave. Por isso, sinaliza para a necessidade de haver um trabalho pedagógico e de gestão, que englobe planejamento estratégico de forma coletiva e interdisciplinar para superação dos dados apresentados.

Nesse sentido, verifica-se também que a maior dificuldade relatada partiu dos professores que talvez por não ter tido uma formação adequada não encontre condições de propor alternativas e realizar mudanças no seu fazer pedagógico e, por sua vez, pode estar acontecendo a reprodução de uma prática pedagógica tecnicista, seguindo o modelo da racionalidade técnica ${ }^{12}$.

Assim, talvez a formação profissional recebida tenha se pautado no modelo acadêmico tradicional, ou seja, o modelo conservador faz com que o conhecimento do conteúdo científico e ou disciplinar adquirido na academia, exerça, se não exclusiva, mas prioritariamente, uma certa influência no seu saber fazer, no sentido de estar a se permitir reproduzir, de só realizar àquela atividade prática, se for daquela forma rigorosa com 'àquelas técnicas', com 'àqueles materiais' e ou àqueles 'instrumentos', sem tentar-se apropriar de outras formas, outras técnicas, outros materiais, outros instrumentos que estejam disponíveis, ou na instituição e ou em empresas, instituições parceiras, que lhe dê esse suporte e possa realizar esta relação teoria prática, promovendo uma ação reflexiva e uma postura proativa diante do cotidiano profissional e conduzindo o processo ensino-aprendizagem renovado, prático e intencional.

e) Processo ensino-aprendizagem e a relação professor- aluno

Sobre estas temáticas, procuramos, basicamente, evidenciar como acontecia e quais fatores que facilitam ou dificultam o processo ensino-aprendizagem; como o docente lida com as dificuldades de aprendizagem; se era estabelecido um acompanhamento individualizado

12 Racionalidade técnica "atividade profissional que consiste na solução instrumental de um problema feita pela rigorosa aplicação de uma teoria científica ou uma técnica" (SCHÖN 1983, p. 21). 
para sanar as dificuldades percebidas no percurso formativo; se estabelecia estratégias de reforço e ou recuperação no contraturno, ou seja, descobrir como se dá a interação didáticopedagógica e como a relação professor aluno pode contribuir no processo educativo.

Como parâmetro para elaboração dessas categorias, utilizamos das diretrizes e normas estabelecidas no documento institucional denominado de 'Regulamento Didáticopedagógico do Ensino' no qual orienta os procedimentos de natureza didático-pedagógica e administrativa adotados no campus e estabelece as competências do professor entre elas à elaboração e cumprimento do Plano Individual de Trabalho-PIT, no qual o professor, resumidamente, descreve suas atividades distribuindo sua carga horária, conforme previsto na Resolução 199/2015 ${ }^{13}$ do Conselho Superior do IFPA-CONSUP, a qual determina que o processo ensino-aprendizagem seja a atividade fim da instituição(art.10).

Esta resolução estabelece as atribuições e responsabilidades conferidas aos docentes e, notamos que, independentemente, do regime de trabalho do professor ser de 20 (vinte) ou 40 (quarenta) horas com DE-Dedicação Exclusiva ou sem DE, nessa resolução prevê 02 (duas) horas semanais para atendimento intraescolar ao aluno (art. 12, Inciso VI) ${ }^{14}$; este atendimento está definido como como aula de reforço, aulas complementares de carga horaria de disciplina, horário de disponibilidade dos professores para esclarecer os alunos sobre exercícios, seminários, pesquisas e outros deste escopo (art. 12, § $2^{\circ}$, grifo meus).

Portanto, dentro das atividades correlatas ao ensino-aprendizagem o professor deverá zelar pelo cumprimento de no mínimo 02 (duas) horas semanais para atendimento individualizado ao aluno. No entanto, pelos depoimentos, constatamos que uma minoria dos professores pesquisados se propõe a trabalhar as duas horas semanais extraclasse, dedicadas ao atendimento individualizado para sanar as dificuldades de algum conteúdo e ou técnica que está sendo proposta para compor o repertório de saberes da sua formação profissional.

Analisando os depoimentos, de forma bem pontual, buscamos compreender como o docente lidava com as dificuldades de aprendizagem, se era estabelecido um acompanhamento individualizado para sanar as dificuldades. Ressaltamos que um desses professores declara que, quando solicitado, trabalha com agendamento e que são feitas adaptações em horários especiais, de acordo com a disponibilidade do aluno, especialmente os que trabalham e estudam e tem horários limitados durante o dia. Entretanto, se estabelece um

13 Resolução 199/2015-CONSUP que regulamenta, no âmbito do Instituto Federal de Educação, Ciência e Tecnologia do Pará a distribuição das atividades na jornada ou regime de trabalho dos servidores ocupantes dos cargos da carreira do magistério do Ensino Básico, Técnico e Tecnológico.

${ }^{14}$ Idem 
acordo de chegar mais cedo ou sair mais tarde do horário normal das aulas para poder ser atendido em sua demanda de dificuldade.

[...] eu trabalho com agendamento, primeiro deixo dito: Olha se você sente alguma dificuldade, se precisar me procurem, às vezes no final da aula os alunos me procuram. Mais tem aqueles alunos também que tem essa dificuldade, mas tem vergonha ou se tem pouco tempo. Então, você tem que chegar nele e falar: Olha estou observando que você está... o que está acontecendo? Porque você está tendo essa dificuldade? [...]. Então, tem essa parte do professor sentir e sacudir também. [...] ou fazer de conta que não está enxergando aquilo ali, e aí caçar um meio de arranjar uma recuperação, depois uma provinha fácil e passar esse aluno (DL1,2015, grifos meus).

Por outro lado, na contramão disso, encontra-se a maioria dos professores que justificam não ter condições de realizar esta atividade por uma série de situações. Dentre elas, a questão do horário de trabalho do professor e também em função da maioria dos alunos, principalmente do turno noturno, trabalharem durante o dia. No entanto, acabam dizendo que este trabalho não deixa de ser realizado, porém, de uma maneira geral acontece no mesmo horário da atividade em sala de aula, atendendo a todos simultaneamente ou, em outro caso, nos dizeres do docente "dispensando os alunos mais letrados e ficando em sala com os que não alcançaram a média".

[...]Como os cursos subsequentes, eles funcionam, manhã, tarde e noite, e às vezes, você não tem, dentro do seu horário específico no contraturno, tem outras aulas que, impede de fazer esse tipo de situação, por isso[...] ]eu, traço o objetivo de alunos foco, aqueles alunos que precisam, aí, eu tento reforçar para todos e para aqueles alunos que ainda não aprendeu (DL3,2015, grifos meus).

Nós sempre tentamos recuperar todos os alunos[...], só que, é complicado, porque, eu tenho alunos graduados e alunos que mal tem o ensino médio, é muito complicado achar o meio termo. Então, eu, como os demais [...], tentamos achar um meio termo, para não ficar muito cansativo, para quem é mais letrado, e muito rápido pra quem não tem tanto conhecimento, e nós sempre fazemos...[...]não fazemos atividades extraclasse, até porque eles trabalham[...] Então...[...]trabalhamos com a margem, uma margem a mais, onde os alunos que conseguirem a média. Beleza! Então, eles estão liberados. Aí, tem uns dois a três dias específicos, para os alunos de menor rendimento. [...], com aula de recuperação, provas de recuperação. Só que isso daí, depende da quantidade de alunos, porque, a gente não vai tirar três a quatro aulas, de todos da turma, por um aluno. Quando, são casos mais isolados, a gente chega diretamente e dá atividades extraclasses, para tentar recuperar ele, agora quando é um caso que vale a pena, a gente... tenta (DB1,2015, grifos meus).

Percebemos claramente que a estratégia utilizada surgiu como uma alternativa para recuperação dos alunos que não atingiram a média de aprovação quando o docente diz "os alunos que conseguirem a média. [...] estão liberados" [...] aí, tem uns dois a três dias 
específicos, para os alunos de menor rendimento. [...], com aula de recuperação, provas de recuperação. Demonstra-se que a percepção da dificuldade dos alunos foi sentida no momento da aferição da nota.

Nesta perspectiva, fundamentalmente, está posto o grande desafio do professor de entender que a sala de aula é um espaço de relações heterogêneas, a qual se constitui de alunos de desempenhos escolares e ritmos de aprendizados diferentes e, portanto, cabe a percepção de intervir e utilizar-se de diferentes estratégias no processo de ensinoaprendizagem, favorecendo o aprendizado a todos e, se ainda assim, não for suficiente, cabe utilizar-se de um paralelo planejamento pedagógico estratégico para realizar um trabalho extra, de atendimento individualizado, conforme previsto nas diretrizes institucionais.

Acreditamos que a ausência de sensibilidade pedagógica tenha influenciado tal conduta e, inclusive, poderá levar o docente a realizar a aula de recuperação, repetindo-se as mesmas estratégias de ensino adotadas que não favoreceu o aprendizado. Portanto, é preciso uma reflexão da prática para que se possa exercer uma mediação ${ }^{15}$ inovadora, mais efetiva e adequada. Importante ressaltar o entendimento de que essa reflexão da prática, também se dará em consequência do processo de formação continuada na qual o professor se apropriará de estudos e experiências que o ajudarão a redirecionar sua prática.

Pôde-se observar que em se tratando da relação professor-aluno, a maioria dos docentes enfatizaram que procuram manter um bom relacionamento, prioritariamente, dentro da Instituição, mas estritamente profissional. Outros ponderaram que até mesmo por morar numa cidade pequena onde todos se conhecem, fica impossível não se relacionar também fora do ambiente escolar.

[...], tem que ter um bom relacionamento com aluno, mas, tem que haver uma diferenciação. Eu, o professor e ali o aluno. [...]. Pelo menos na minha percepção, o aluno sempre está aberto a aproximação, mas o professor pode estar ou não. Eu vejo assim, eu posso está até errado. Mas, eu percebi que a aproximação, se você deixar, ela se torna bem pessoal. E aí, eu tenho critérios para os limites, eu digo assim, tem que ter a relação professor-aluno a gente tem que se aproximar, mas não dá para extrapolar, tem que ter limite, não pode ir para o pessoal. Isso é um critério meu. Porque, senão você acaba se envolvendo na vida do aluno (DB2,2015).

Percebemos, neste depoimento, que o docente reconhece que tem que haver, porém, ao mesmo tempo, constata uma percepção um pouco limitada da real finalidade de se ter uma

15 O termo mediação entendido como intervenção, intercessão, intermediação. Mello (1985, p.24-25), diz que [...] mediação refere-se ao que está ou acontece no meio, ou entre duas ou mais coisas separadas no tempo e/ ou no espaço. [...]o movimento se realiza por mediações que fazem a passagem de um nível a outro, de uma coisa à outra, de uma parte à outra, dentro daquela realidade. 
boa interação com os alunos, não se trata de uma aproximação por questão apenas de afeto, mas muito mais que isso, de estabelecimento de uma relação bidirecional de forma produtiva. Neste caso, as liberdades não entram em conflito, mas se tornam ocasião de diálogo e de experiências significativas tanto em âmbito pedagógico quanto das próprias vidas.

Diante disso, se faz necessário partir da seguinte reflexão: o estabelecimento de ensino é uma instituição social, que legalmente passa a ser o único local de construção de saberes sistematizados, há quem duvide, mas não será este o mérito desse estudo. No geral, a relação estabelecida entre os dois sujeitos professor/aluno se torna a condição primordial para que ocorra o processo de aprendizagem.

Libâneo (1994) corrobora na compreensão desta relação intencional, quando diz que:

O professor não apenas transmite uma informação ou faz perguntas, mas também ouve os alunos. Deve dar-lhes atenção e cuidar para que aprendam a expressar-se, a expor opiniões e dar respostas. O trabalho docente nunca é unidirecional. As respostas e opiniões mostram como eles estão reagindo à atuação do professor, às dificuldades que encontram na assimilação dos conhecimentos. Servem, também, para diagnosticar as causas que dão origem a essas dificuldades (LIBÂNEO,1994, p.250)

Daí a necessidade de se estabelecer permanentemente uma relação professor-aluno harmoniosa, respeitosa e principalmente comprometida, de forma a criar condições satisfatórias para o êxito das práticas educativas, levando em conta às necessidades do aluno, ou seja, o professor precisa se envolver constantemente numas práxis reflexiva, mediadora e compreender a importância fundamental que seu papel assume na vida pessoal, escolar e produtiva de seus alunos.

Para Freire (1989) é preciso haver uma valorização do diálogo como importante instrumento na constituição dos sujeitos. Para ele só é possível uma prática educativa dialógica por parte dos educadores, se estes acreditarem no diálogo como um fenômeno humano capaz de mobilizar o refletir e o agir dos homens e mulheres. Na compreensão da prática dialógica ele diz:

[...], o diálogo é uma exigência existencial. E, se ele é o encontro em que se solidarizam o refletir e o agir de seus sujeitos endereçados ao mundo a ser transformado e humanizado, não pode reduzir-se a um ato de depositar ideias de um sujeito no outro, nem tampouco tornar-se simples troca de ideias a serem consumidas pelos permutantes (FREIRE, 1989, p. 91).

Nessa perspectiva, o professor de EPT não é visto como um mero transmissor de conhecimentos, mas como um mediador, assumindo um papel mais humanizado em sua 
prática docente de alguém que dá ouvidos aos alunos e leve em consideração os aspectos emocionais e afetivos, principalmente que seja um educador capaz de articular as experiências dos alunos com o mundo produtivo, permitindo que desenvolvam comportamentos pró-ativo, crítico e reflexivo.

f) Avaliação da aprendizagem

Neste tema indicador, procuramos compreender a percepção dos professores da finalidade da avaliação na prática educativa, quais os instrumentos avaliativos que eles utilizavam e se era hábito oferecer o feedback dessas avaliações. Observamos que a maioria dos professores focam seus apontamentos, a princípio, pela prática da avaliação, como instrumento para dar nota, como se fosse uma sentença final, não na finalidade pedagógica que se baseia na perspectiva de reorganização do processo ensino-aprendizagem.

Por outro lado, observamos também um descontentamento da mensuração da avaliação por nota, exigência formal prevista no Regulamento Didático-Pedagógico, o qual prevê que a aprovação na disciplina, independente do regime do curso ser modular ou semestral será realizada por dois momentos, com a seguinte fórmula: (i) somatória de duas notas dividida por 2(dois), o resultado será a média bimestral e, se essa média bimestral for igual ou superior a 7,0 (sete) o aluno estará aprovado (ii) em caso dessa média bimestral for inferior a 7,0(sete) deverá realizar uma prova final, esta nota, portanto, será somada com a média bimestral e dividida por 2(dois), sendo igual ou superior a 7,0 estará aprovado.

[...] ]eu sou meio contrário, a algumas coisas que o sistema adota, que é o sistema de notas, acho que isso é meio complicado para a gente está dizendo, se o aluno está apto ou não está apto para desenvolver, porque os cursos que eles têm, eles podem seguir vários caminhos[...], a nota é insuficiente. Outra coisa que eu acho que deveria ser estendido, inclusive aos cursos Técnicos, é a questão do trabalho de conclusão, infelizmente, hoje só os cursos de graduação e os tecnológicos que exigem isso. Acho que é o momento de se avaliar também os nossos cursos técnicos, o trabalho de conclusão. É uma oportunidade, que a gente deixa passar (DL2,2015).

Nesta perspectiva, convém então distinguir 'avaliação, nota e prova'. Segundo Vasconcellos (2000),

Avaliação é um processo abrangente da existência humana, que implica uma reflexão crítica sobre a prática, no sentido de captar seus avanços, [...], suas dificuldades e possibilitar uma tomada de decisão sobre o que fazer para superar os obstáculos[...]. A Nota seja na forma de número (ex.:0-10), conceito (A, B, C, D) ou menção (ex.: Excelente, Bom, Satisfatório, Insatisfatório), é uma exigência formal 
do sistema educacional. Podemos imaginar um dia em que não haja mais nota na escola- ou qualquer tipo de reprovação-, mas certamente haverá necessidade de continuar existindo avaliação, para poder acompanhar o desenvolvimento dos educandos e ajudá-los em suas eventuais dificuldades.

Prova é apenas uma das formas de se gerar Nota, que, por sua vez, é uma das formas de se avaliar. Assim, podemos atribuir Nota sem ser por Prova, bem como podemos avaliar sem ser por nota[...] (VASCONCELLOS, 2000 p. 44, grifos do autor).

Ainda, segundo o Art. 260 do Regulamento Didático-Pedagógico, “a avaliação da aprendizagem deve ser um processo amplo, contínuo, gradual, cumulativo, sistemático e cooperativo envolvendo todos os aspectos qualitativos e quantitativos da formação do educando, conforme prescreve a Lei n ${ }^{\circ}$ 9.394/96".

Constatamos nesse estudo que a maioria dos professores se referiram a questão da aplicação de prova como uma exigência para se dar a nota, que, por sua vez, verifica-se através de alguns depoimentos uma distorção no entendimento dessa exigência formal, onde a exigência no regulamento da Instituição se refere a aferição do resultado final da avaliação, mas não, necessariamente, que o processo avaliativo ocorra através de um único instrumento avaliativo denominado de prova, pelo contrário:

A avaliação da aprendizagem ocorrerá de forma diversificada e de acordo com a peculiaridade de cada componente curricular, por meio dos seguintes instrumentos: I) Elaboração e execução de projeto; II) Experimento; III) Pesquisa bibliográfica; IV) Pesquisa de campo; V) Prova escrita e/ou oral; VI) Prova prática; VII) Produção técnico-científica, artística ou cultural; VIII) Seminário" (Art. 265, idem).

Pôde observar também que, apesar de enfatizarem que utilizam de avaliação qualitativa, entretanto, percebemos a predominância do caráter mais somativo do que formativo, mais para aferição de uma nota. Nota-se também avaliação sendo utilizada apenas para avaliar um dos sujeitos, no caso o aluno, não do processo ensino-aprendizagem, ou seja, não percebe a utilização do instrumento de forma a diagnosticar, pelos resultados, o que precisa ser redirecionado, melhorado na sua prática docente, de forma a garantir uma aprendizagem a todos. Dentre outras, algumas percepções que foram evidenciadas:

Eu utilizo as provas, discursivas, opções de verdadeira ou falsas, ou marcar, provas de cálculos. São bem focadas. Agora, eu levo em conta mais alguns fatores, [...]a frequência, [...] a participação, [...]o interesse, que tem alguns que não tem muito interesse, que estão lá por trás, e ainda não conseguiu despertar o interesse. Existe isso. Então, levo em conta esses fatores, e eu faço o "teste" para dar a nota. O feedback é dado, mais nas correções das provas, a gente senta, corrigir, chama o aluno, questiona porque que ele errou aquilo, já que foi dado e ministrado na aula? Mas existe (DB2,2015).

Avaliar é uma coisa [...]muito difícil, julgar é difícil, mas[...] não sou um professor quantitativo, gosto de trabalhar muito com o qualitativo[...] sei que [...]uma nota, 
[...]faz parte do padrão da instituição, é o Regimento. Mas, os [...]avalio muito[...]por produção diária, [...], então, eu vejo que o sistema de avaliação, ele tem que mudar[...] eu vejo, a avaliação de uma forma global e não de uma forma fragmentada, onde tem aquela nota e tem que dividir por 2, e dá uma média, ao meu ver, a avaliação funciona, mas de forma qualitativa do que quantitativa. Apesar, da instituição ter regimento e a gente seguir aquele padrão (DL3,2015).

[...]dentro das minhas avaliações eu tenho a forma de avaliação objetiva, tem a avaliação presencial de trabalhos e avaliação participativa e continua dos alunos dentro da sala de aula, então, eu uso várias ferramentas e nas aulas práticas os alunos que melhor desenvolve e que participam da aula[...] Então esse aluno não pode ser avaliado igual aos outros, ele não pode ter o mesmo mérito, a mesma nota que os outros[...] eu não tenho o hábito de fazer de novo a correção da prova na sala de aula, até mesmo porque, eu não sou adepto a novidades em prova. Na minha prova cai o que eu passei, dos exercícios que eu já fiz[...] (DB3,2015).

Acreditamos que a principal finalidade da avaliação seja garantir a todos os alunos a construção do conhecimento através da efetiva mediação da aprendizagem e segundo Vasconcellos (2000) “[...] O sentido maior da avaliação é: Avaliar para que os alunos aprendam mais e melhor".

g) A formação dos alunos os prepara para atuar no mundo do trabalho

Finalizando as categorias desse eixo temático, de forma bem pontual, momento de suas considerações finais, questionamos ao docente se as formações que os alunos recebem na Instituição são suficientes e os prepara para atuar no mundo do trabalho. Constatamos, que os aspectos negativos se sobressaem e ainda justificam seus posicionamentos, a saber:

\footnotetext{
Alguns cursos sim, outros cursos não[...] essa questão toda, em termo de materiais[...]por exemplo, sem ter um laboratório de tratamento de água. Como vai saber medir a água? Então, são coisas básicas que um técnico em saneamento vai, sem aquele domínio[...]os cursos que precisam de laboratório aqui, para ter uma prática mais efetiva, aí a formação sai muito a desejar[...]aqueles que passaram só com aquela carga horária, dentro da sala de aula, só no que foi exigido eu considero insuficiente, sem medo de errar (DL1,2015).

$\mathrm{Eu}$, considero inadequada. Apesar de ser professor do quadro[...]a gente não pode mascarar[...] ]eu fico muito preocupado enquanto professor, de tudo que já comentei aqui[...]aluno que sai para o mercado de trabalho[...]vou usar o termo, "meia boca", ele não sai um profissional[...]sai mais com a teoria do que com a prática, então, falta muita coisa para o Instituto em termos de cursos técnicos[...] (DL3,2015).

O curso de eventos sim[...] já os de marketing, acredito que não, porque nós não temos ainda os programas necessários, além da parte de multimídia, não temos as impressoras necessárias, nós nem temos a qualificação necessária para ministrar o curso[...] então, a gente está tendo muita dificuldade nesse sentido (DB1,2015, grifos meus).
} 
Poderia ser melhor[...]se todas as nossas deficiências tivessem sido atendidas, se tivesse comprados esses livros voltados para o nível técnico, tivesse o laboratório de campo, tivesse os equipamentos do laboratório e o incentivo ao professor e aluno. Se tivesse isso aqui, seria destaque[...]hoje digo que não é. É, Regular (DB2,2015).

O que a gente percebe em relação aos conhecimentos básicos[...] existem uma dificuldade eu acho que não é um privilégio de Conceição, mas, em relação à física e matemática, esse conhecimento é bem complicado. E muitos dos nossos cursos técnicos, é a base, e isso tem gerado algumas falsas expectativas, tanto por parte da instituição, quanto por parte das pessoas que ingressam em determinado curso. Então isso, tem que ser trabalhado de uma melhor forma, eu acho que a Instituição tem o papel (DL2,2015).

[...]a nível de Sul e Sudeste, acredito que a gente ainda deixa muito a desejar, a nível de Centro Oeste, acredito que a gente está quase que equiparando, até pelas, nossas notas[...]agora, a nível de Norte e Nordeste, eu acho que a gente não deixa a desejar, não se falando tanto nas zonas metropolitanas que são bem mais avançadas. Mas se a gente falar de interior do Brasil, nós não estamos mal[...]DB3,2015).

Percebemos que a predominância dos depoimentos se voltam para aspectos externos que inviabilizam um processo ensino-aprendizagem adequado, quer seja pela ausência de aulas práticas, quer seja pela falta de laboratórios, equipamentos. Por outro lado, verificamos as alegações relacionadas a dimensão cognitiva, seja pela falta de conhecimentos básicos, considerados pré-requisitos para prosseguir com os ensinamentos destinados em curso de ensino técnico, como também a questão, de forma bem sincera por alguns docentes, o reconhecimento da ausência de qualificação necessária para ministrar o curso. Notamos que algumas situações têm sido recorrentes.

\subsection{Dados e análise da pesquisa realizada com os alunos dos cursos técnicos subsequentes}

Participaram dessa pesquisa um total de 15 (quinze) alunos matriculados e que estavam frequentando em um dos 5 (cinco) cursos técnicos subsequentes no segundo semestre do ano de 2015. Definimos que seriam analisados 03 (três) alunos de cada curso. Delimitamos, assim, para se ter um quantitativo de alunos semelhantes para cada curso. Sendo enviado o formulário via Web.

Foram formuladas perguntas fechadas, a título de caraterização para identificação do grupo participante e perguntas abertas com a finalidade de coletar as percepções sobre o processo ensino-aprendizagem. Ou seja, havia uma intencionalidade preestabelecida, a qual tinha a finalidade de estar fundamentando as inferências que pudessem permitir afirmações e interpretações mais fidedignas. 
Inicialmente, se torna relevante conhecer a descrição do perfil dos alunos que participaram desta pesquisa, uma vez que a contextualização traz uma certa segurança na confirmação ou não do que se pretende investigar se a relação da formação do docente de EPT influencia no processo de ensino-aprendizagem. O Quadro 5, na sequência, apresenta aspectos que caracteriza melhor os 15 (quinze) alunos, sujeitos que responderam o questionário da pesquisa.

Quadro 5 - Demonstrativo do Perfil dos Alunos Pesquisados

\begin{tabular}{|c|l|c|c|c|c|}
\hline Sexo & Faixa etária & $\begin{array}{c}\text { Módulo } \\
\text { Que frequenta }\end{array}$ & Nível escolar & $\begin{array}{c}\text { Se } \\
\text { trabalha }\end{array}$ & $\begin{array}{c}\text { Se estuda } \\
\text { Em outra Instituição }\end{array}$ \\
\hline \multirow{3}{*}{ F - 11 } & 15 a $20-3$ & IV -5 & & & Sim-3 \\
M - $30-7$ & III -5 & Superior -07 & Sim-7 & Não-12 \\
& acima $40-2$ & II -4 & Ens.Médio-08 & Não-8 & \\
\hline
\end{tabular}

Fonte: Pesquisa de dados, 2015.

A Instituição nos seus cursos técnicos subsequentes tem alunos com perfis bem diversificados. Notamos que possui um grande número de alunos que já concluíram o nível superior, mas estão buscando uma formação técnica profissionalizante. Por outro lado, também se constata o contrário, alunos que estão fazendo o curso técnico e estudando uma graduação em uma outra instituição. Esses dados podem estar demonstrando um fator sociocultural relevante. Talvez poderia inferir-se que, a população jovem do município, independentemente de estar trabalhando ou não, estão buscando sempre elevar seu nível de qualificação. Constatamos também uma maior incidência do motivo que os levaram a escolha do curso, sendo predominante a vontade de obter um curso profissionalizante, conforme representado no Gráfico 2.

Gráfico 2 - Qual o motivo que levou a escolher o curso técnico?

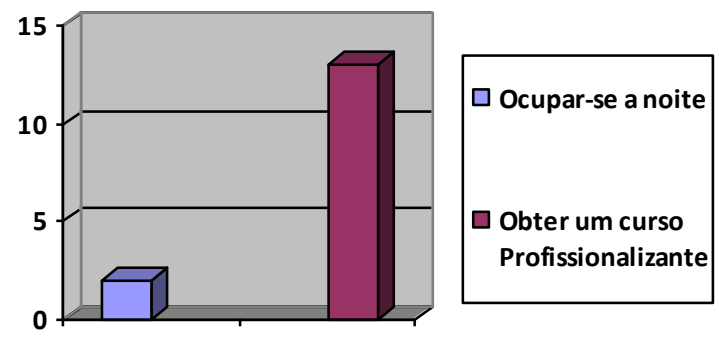

Fonte: Pesquisa de dados, 2015. 
A entrada na Instituição, fundamentalmente, se dá pela possibilidade de obter um curso técnico profissionalizante. Nesse sentido, reiteramos o importante papel da Instituição, a necessidade de investimento em condições adequadas, infraestrutura, materiais didáticos, professores bem qualificados, biblioteca com acervo amplo e com livros técnicos por área e curso, bem como equipamentos para execução das aulas práticas, apoio e incentivo às visitas técnicas para que consiga atender as expectativas dos alunos e o perfil do egresso do curso.

Conforme mencionado anteriormente, a compreensão dos dados tem se pautado pela técnica de análise de conteúdo. Nesse contexto, o Quadro 6 demonstra, como eixo temático, o que originou tal pesquisa junto aos alunos, a categoria geral para caracterizar o 'como as aulas acontecem' e as subcategorias foram preestabelecidas na elaboração das questões com a finalidade de ser o mais objetiva possível na obtenção das respostas.

Foi realizada uma pré-análise dos dados, a partir da elaboração de quadros, sobre os quais foram sendo colocado as respostas, aspectos comuns e ou inter-relacionados que foram agrupados à ideia principal. Em seguida, fez-se a quantificação e, por último, a produção da análise geral, evidenciando os aspectos de maior incidência nas respostas às questões propostas, as quais serão analisadas na sequência em que aparecem. Ressaltando que todas as perguntas continham um texto complementar (Texto ajuda), com maiores explicações e possibilitando um norte ao aluno a responder sobre àquele aspecto em investigação.

Quadro 6: Aspectos do processo ensino-aprendizagem na percepção discente

\begin{tabular}{|c|c|l|}
\hline Eixo Temático & Categoria & \multicolumn{1}{|c|}{ Subcategorias (o que foi analisado) } \\
\hline & & a) Planejamento \\
Percepção sobre o & & b) Dificuldades de aprendizagem \\
processo ensino- & Como acontecem & c) Relacionamento professor/aluno \\
aprendizagem & as aulas & d) Aulas práticas/visitas técnicas \\
& & e) Avaliação da aprendizagem \\
\hline
\end{tabular}

a) Planejamento

O objetivo dessa subcategoria foi conhecer a percepção dos alunos sobre o cotidiano da sala de aula, se percebiam que as aulas dos professores tinham sido planejadas, se havia estratégias de ensino previamente pensadas que promovesse o aprendizado de cada aluno; se o professor utilizava vários recursos didáticos e atividades visando a construção do conhecimento por parte de todos. 
Diante dos resultados obtidos, identificamos aspectos comuns citados pelos alunos os quais se referem a percepção dos mesmos em relação a falta de experiência do professor em sala de aula, o que pode inferir que por traz destas respostas a questão da não formação para atuar na docência pode estar sendo evidenciada pelos alunos. Todavia, chega-se a esta conclusão quando se depara com as seguintes falas que representam as respostas de maior incidência:

\footnotetext{
Algumas aulas sim, outras percebemos que alguns professores não têm experiência em sala de aula, sabem o conteúdo, mas não tem dinâmica para explicar (A1,2015).

Não. A maioria dos professores não planejam as aulas, são sempre da mesma forma, só apresentação de slide (A9,2015).
}

Percebemos uma distinção pelos alunos de perfis diferenciados na conduta das aulas pelos professores e isso, pode-se tornar, parafraseando Vasconcellos (2003) um 'vazio pedagógico', como visto no referencial teórico, aulas sem o envolvimento, sem estabelecimento de uma relação proximal poderá estar ocorrendo devido "[...] o professor não sabe o que fazer em sala de aula (não se sabe fazer algo diferente do que aquilo que aprendeu: transmissão-reprodução); a formação tida não dá conta da realidade concreta com que se defronta $[\ldots]$ ". Esses têm sido alguns fatores que podem ocasionar esse vazio pedagógico, caracterizado por um ensino sem mediação, onde o professor pode não estar conseguindo envolver-se e planejar aulas atraentes e significativas aos seus alunos, consequentemente, se tudo isso acontecer, o ensino se torna insuficiente e não empolgante, como diz um aluno: "No início os alunos entram empolgados, porém foram muitos os desistentes, e um dos fatores foram às formas de ministrar as aulas, sempre slide na grande maioria” (A6, 2015).

Sobre essa questão das aulas serem sempre da mesma forma, através de um único instrumento didático, talvez, diante do que se tem discutido até agora, possa inferir uma certa relação com o que os alunos identificaram. Os professores têm o conhecimento da área, mas por outro lado lhes falta a articulação desses saberes com os saberes pedagógicos que fundamentam a necessidade de aulas mais dialogadas, dinâmicas, explicativas que os envolvam e conduzam a um aprendizado que tenha certa significância para os mesmos.

b) Dificuldades de aprendizagem

Procurou compreender a percepção do aluno sobre como a questão da dificuldade de aprendizagem é percebida pelo professor e se, em razão disso, há mudança na maneira de 
apresentar os conteúdos, ou seja, se ele percebe a preocupação do professor em ajudar o aluno que tem dificuldades em assimilar os conteúdos propostos. Percebemos que a maioria dos alunos continuam a evidenciar, diferenciadas condutas docentes em sala de aula, os quais identificam a preocupação apenas de alguns professores do que de outros, de estarem mudando as estratégias de ensino para uma melhor compreensão dos conteúdos. As falas mais comuns se referem a:

\footnotetext{
Alguns professores..., não todos! Mas alguns, usa uma dinâmica diferente para que o aluno venha aprender e entender (A5,2015).

As dúvidas existentes são sanadas em sala de aula (A,13,2015).
}

Pelo menos eu não percebi nenhuma vez essa mudança de ensinar o aluno que não entendeu a matéria[...] $(\mathrm{A} 8,2015)$.

Tem uns que se preocupa bastante, e outros não liga muito não. Tanto faz como tanto fez $(\mathrm{A} 4,2015)$.

Os resultados obtidos nessa questão vêm de encontro com o que também foi perguntado aos docentes, ou seja, confirma o que foi relatado pelos professores que este trabalho de dificuldade de aprendizagem, quando realizado, acontece apenas em sala de aula, sinalizando, talvez, para que de fato o cumprimento das duas horas de atividades intraescolar prevista na Resolução 199/2015 ${ }^{16}$ poderia estar contribuindo para amenizar a situação.

Por outro lado, só reforça o que já foi falado anteriormente, de que este é um dos grandes desafios dos professores de trabalhar com alunos de desempenho escolar peculiar e ritmos de aprendizados diferentes e, portanto, cabe a percepção de intervir e utilizar-se de diferentes estratégias no processo de ensino-aprendizagem, favorecendo o aprendizado a todos e, se ainda assim, não for suficiente, cabe utilizar-se de um paralelo planejamento pedagógico estratégico para realizar um trabalho extra horário regular de sala de aula, de atendimento individualizado.

c) Relacionamento professor-aluno

16 Esta Resolução estabelece que na distribuição da carga horária o professor direcione 02(duas) horas por semana para atendimento intraescolar: aula de reforço, aulas complementares para esclarecer aos alunos sobre exercícios, seminários, pesquisas e outros (art. $12, \S 2^{\circ}$ ). 
Como se dá o relacionamento professor e aluno? Esta pergunta foi feita com o objetivo de inferir até que ponto o clima em sala de aula se mostrava propício para a produção do conhecimento; se havia um clima de diálogo constante entre alunos-professor e vice-versa; se o aluno sentia certa liberdade em estar participando das aulas, expondo suas ideias, tirando suas dúvidas; e se o professor levava em consideração os aspectos psicológicos e sociais na sua forma de ministrar as aulas.

Constata-se que há uma certa imposição de limites por alguns professores na visão dos alunos, mas, no entanto, na percepção dos alunos esse relacionamento acontece por uma questão de amizade e do professor gostar do trabalho que realiza.

\footnotetext{
A grande maioria dos professores estão ali para ministrar aula, somente isso, sem o envolvimento de aspectos pessoais dos alunos (A2,2015).

Hoje em dia os professores se relacionam com alunos como se fosse grandes amigos, claro aquele professor que ama seu trabalho e quer ser visto como um herói, ou seja exemplo $(\mathrm{A} 5,2015)$.
}

Observamos pelas percepções dos alunos, que a maioria considera um bom relacionamento. Entretanto, demonstraram perceber uma relação verticalizada, somente quando o professor se envolve, ama o trabalho que faz e quer ser reconhecido, este relacionamento tem sido mais próximo.

d) Aulas práticas/visitas técnicas

Nesta subcategoria foram elaboradas perguntas com o objetivo de identificar se em todas as disciplinas o professor estabelecia articulação teoria/prática; se tem havido momento de aplicar na prática, aquilo que foi aprendido em sala de aula; se tem havido visitas técnicas, momento de visitar as empresas ou instituições para conhecer o cotidiano de determinada atividade, no lugar que elas acontecem.

Nota-se que esse se parece o 'calcanhar de Aquiles' da Instituição, as questões da ausência de aulas práticas e visitas técnicas foram lamentadas por quase a maioria absoluta nas respostas dos alunos. As respostas obtidas possuem uma certa congruência com o reconhecimento dos professores da real insuficiência de aulas práticas e visitas técnicas. As falas que melhor expressam esta situação foram:

Estamos concluindo o curso de Saneamento, no entanto, nunca tivemos oportunidade de ter aulas em laboratórios, pois o mesmo está inativo no instituto. Esse é um dos maiores problemas, foram 18 meses de aulas na sua grande maioria 
teórica por meio de slide. Com grande luta tivemos apenas 1 visita técnica, contudo esse é um dos aspectos negativos que podemos citar (A14,2015).

Não. Assim que inicia o curso só temos aulas teóricas, e como disse anteriormente, por sinal muito mal dadas. As aulas práticas, quando temos, é com ajuda de outras instituições, tais como os bombeiros de Redenção. O professor não tem iniciativas próprias de meterem a mão na massa e fazerem o trabalho deles, tudo fica a cargo do instituto (A10,2015).

Pouquíssimas, tanto que nesse período todo, tivemos só três visitas. Até falta de combustível foi motivo de cancelar visitas (A8,2015).

Aulas fora da sala de aula cativa os alunos, visitas técnicas, aulas práticas, são de grande importância em um curso tão procurado. No início os alunos entram empolgados, porém foram muitos os desistentes, e um dos fatores foram as formas de ministrar as aulas, sempre slide na grande maioria $(\mathrm{A} 6,2015)$.

Essas respostas obtidas revelam que as aulas práticas precisam ser implementadas nas práticas pedagógicas de todos os professores. Caso contrário, poderá acontecer o mesmo mencionado na metáfora irônica de Jaques Busquet, sobre o curso de preparação de nadadores, onde seus alunos obtiveram uma sólida preparação. No entanto, a experimentação que faz parte do conhecimento necessário, o contato com a água, só lhes foi concedido quando foram lançados ao mar, em águas bem profundas, em um dia de temporal. Nessa perspectiva, é como se dissesse "salvem-se quem puder". Esta percepção nos faz relacionar também com àquilo que Paulo Freire (2014) fala da prática educativo-crítica que "a reflexão crítica sobre a prática se torna uma exigência da relação Teoria/Prática sem a qual a teoria pode ir virando blá-blá-blá e a prática, ativismo".

e) Avaliação da aprendizagem

Esta subcategoria teve o propósito de identificar como estava acontecendo o processo de avaliação da aprendizagem, quais eram os instrumentos que o professor utilizava e se dava retorno das avaliações de forma a esclarecer, retomar através de discussão dos resultados dos pontos mais importantes que deixaram de ser mencionados pelos alunos ou, se apenas, utilizava o instrumento para verificação do aproveitamento escolar e concedia a nota.

Todas as respostas dos alunos enfatizaram que os professores utilizam de provas, seminários e trabalhos escritos. Percebemos, neste caso, que a avaliação nem sempre tem tido uma conotação de processo avaliativo, utilizado como mecanismo para subsidiar seu trabalho pedagógico. Isso pôde ser percebido quando falam da ausência do feedback na correção das avaliações, momento propício para promover no/com o aluno a reflexão sobre o que deixou 
de ser mencionado e, até mesmo, no momento da correção compartilhada retroalimenta algo que deixou de ser contemplado, suprimindo as dúvidas, por ventura existentes, que o levou a não obter o êxito esperado.

A avaliação da aprendizagem não se restringe a utilização de um instrumento para aferição de nota, mas perpassa por um processo educativo mais amplo. Luckesi (2002) define como objetivo final do uso da avaliação como "uma tomada de decisão que direcione o aprendizado e, consequentemente o desenvolvimento do educando". Constatamos também, nesse item que, os depoimentos dos alunos têm congruência com as informações prestadas pela maioria dos professores, quando dizem não realizar esta devolutiva. As respostas que evidenciaram tais fatos:

Prova, presença e trabalhos, raramente dão retorno do porquê da nota $(\mathrm{A} 2,2015)$.

Ainda usam os métodos antigos de provas e trabalhos, deviam avaliar também a participação dos alunos na sala de aula, se esse aluno ajuda com seus conhecimentos de vida, na interação com outros alunos (A8,2015).

A avaliação se dá por meio de seminário e avaliações escrita. Os docentes não costumam dar retorno de suas avaliações. Tanto é que, quando o discente não alcança a média, essa pessoa só é comunicada após um mês ou mais (A12,2015).

Para Luckesi (2002), a avaliação precisa estar carregada de uma intencionalidade, ou seja, ela só poderá funcionar efetivamente num trabalho educativo em que há o interesse em que o aluno aprenda e se desenvolva, ou seja, não deve ter conotação apenas de verificação. O autor diferencia a avaliação da verificação: “[...] A avaliação é um diagnóstico da qualidade dos resultados intermediários ou finais; a verificação é uma configuração dos resultados parciais ou finais. A primeira é dinâmica e a segunda, estática."

Percebemos que o processo avaliativo necessita de uma intencionalidade que vislumbre outras oportunidades de se realizar o trabalho educativo de forma a estar contemplando a compreensão por parte de todos os alunos que, neste caso, em específico dos cursos técnicos, desempenharão uma atividade profissional, portanto, a ele será exigido não somente competência, mas habilidades, condições de trabalhar e colaborar com o desenvolvimento econômico do país. 


\section{PRODUTO TÉCNICO}

Toda pesquisa realizada, precede de uma intencionalidade e, no caso deste estudo não foi diferente por dois motivos: primeiro que trata de uma pesquisa realizada no lócus de trabalho da pesquisadora que teve a pretensão de identificar uma situação que precisava ser melhor compreendida e trabalhada em relação a influência da formação do professor de EPT no processo ensino-aprendizagem e, como segundo aspecto, pela configuração do mestrado profissional, fazer a exigência de, com base na revisão teórica e mediante o resultado da pesquisa realizada, propor um produto técnico, ou seja, propor um projeto de intervenção na realidade, com a finalidade de criar mecanismos que possam subsidiar uma possível superação da problemática suscitada através do estudo.

Assim, nessa perspectiva, acreditamos que esta pesquisa não terá somente o caráter investigativo na descrição de uma realidade, mas tomará uma direção mais sistêmica propondo uma alternativa viável que contribuirá para a transformação da realidade encontrada desenvolvendo com melhor qualidade o ensino técnico profissionalizante.

\subsection{Laboratório Pedagógico: espaço de formação docente e integração de saberes}

De acordo com os dados levantados, constatamos que a maior dificuldade em conduzir o processo ensino-aprendizagem de forma significativa, contemplando os anseios do corpo discente vem dos docentes bacharéis, ou seja, daqueles docentes que não obtiveram formação para a docência. Logo, esta lacuna, na sua formação, tem influenciado diretamente no seu fazer pedagógico. Entretanto, percebemos que os docentes licenciados, embora menos, também salientaram encontrar dificuldade, por se tratar de uma modalidade da educação que possui uma especificidade diferente das abordadas em sua formação e ou experiência enquanto docente na educação básica e pela insuficiência de recursos para aulas práticas.

Esta conclusão parte da análise do conteúdo dos depoimentos dos professores e se confirma mediante a percepção dos alunos quando se referem à postura desses professores na condução de suas aulas. Por outro lado, notamos que a EPT tem sua epistemologia e precisa ser objeto de formação para os profissionais que nela trabalham, no sentido de criar melhores condições da compreensão do fenômeno educativo direcionado a esta parcela da população que buscam a realização de um curso profissionalizante para dar um novo significado para sua vida pessoal e profissional. 
Nesse contexto, as transformações atuais no mundo do trabalho face às mudanças evolutivas na sociedade, as inovações tecnológicas, a informatização que conecta as várias partes do mundo em tempo real, se faz compreender que, renovadas demandas formais de educação surgem para a formação de um cidadão com postura ativa, crítica e ética, logicamente, não tão exclusivamente para atender aos objetivos de produtividade de uma sociedade extremamente capitalista, mas como forma de assegurar uma educação mais humana e pluralizada com condições de conquistas de liberdade, de autonomia profissional e da própria constituição de cidadania. Face ao exposto, a formação do docente que irá atuar na educação profissional institucionalizada assume um desafio gigantesco.

Contudo, mediante os referenciais que serviram de fundamentação para esse estudo, verificamos que a formação docente para atuação na EPT de forma mais sistematizada não tem sido objeto de implementação de políticas públicas. Porém, ressalta-se que, com o surgimento da expansão dos IFs, têm acontecido algumas discussões, mas ainda não encontra nenhuma proposta consolidada, em âmbito nacional, por parte do Estado de formação para esse público em específico. No entanto, sinaliza a proposta de uma capacitação a ser realizada pelas próprias instituições no formato de formação complementar e ou formação continuada. Portanto, cabe à instituição assumir o compromisso de complementar essa formação. Portanto, diante do que foi constatado nesta pesquisa, será proposto à gestão da Instituição a criação de um Laboratório Pedagógico-LP que consiste num espaço institucionalizado reservado exclusivamente para a formação continuada dos professores da Instituição, haja vista ter sido uma indicação dos próprios professores que alegaram não haver momentos, com uma durabilidade maior para formação e planejamento coletivo entre os pares, o que tem dificultado traçar um trabalho integrado e interdisciplinar na perspectiva de articulação com as diversas disciplinas do mesmo eixo tecnológico, evitando assim um trabalho fragmentado.

Com a implementação do LP, acreditamos que poderá estar sendo viabilizado uma sistemática inovadora na formação continuada como forma de estar mobilizando e integrando os saberes da docência, levando em consideração os contextos reais das práticas pedagógicas, contribuindo para a complementação de sua formação, a qual, inclusive, não foge as determinações contidas nas metas do PNE (2014-2024) que refere como deve acontecer a formação inicial e continuada dos professores:

15.13) desenvolver modelos de formação docente para a educação profissional que valorizem a experiência prática, por meio da oferta, nas redes federal e estaduais de educação profissional, de cursos voltados à complementação e certificação didáticopedagógica de profissionais experientes (Brasil, 2014). 
Esta proposta da criação do Laboratório Pedagógico acredita-se ser uma inovação educativa, caracterizada pela sua dimensão intencional e a possibilidade viável de concretização, uma vez que partiu da demanda dos professores e reforçado nas falas dos alunos quando percebem a falta de planejamento e experiência de alguns professores em lidar com a docência. Segundo Campolina e Martinez (2013):

Um dos pressupostos que afirmam a importância de inovações na educação é que elas representam possibilidades de resgatar as instituições de problemas decorrentes do afastamento de políticas do Estado, aliada às demandas por melhorias na qualidade do processo educacional. Sob esse ponto de vista, a inovação constitui um meio para transformar os processos educacionais e as instituições escolares (CAMPOLINA \& MARTINEZ, 2013, p. 326).

Ressalta-se outro fator favorável, a existência de uma infraestrutura viável do local, apenas será necessário fazer algumas adaptações e remanejamentos de setores que funcionam no espaço que será indicado para o funcionamento do LP.

Importante salientar também que, como se trata de um projeto inovador nessa instituição de ensino e, para que o mesmo alcance o êxito desejado, irá depender da cultura escolar e organizacional e, principalmente, do envolvimento de todos os atores em empreender esforços com a intenção de beneficiar a comunidade escolar. A inovação escolar pode ser entendida, segundo Campolina (2012),

[...] um processo complexo realizado por indivíduos que, por meio da promoção e implementação de elementos novos como práticas, métodos, ideias e recursos, visa intencionalmente promover mudanças com o objetivo de gerar melhorias no contexto educativo concreto. Processo no qual atuam elementos de ordem histórica, social e ou individual" (CAMPOLINA, 2012 p. 79).

Diante dessas premissas, juntamente com o respaldo legal das Diretrizes Curriculares Nacionais para a formação inicial e continuada dos profissionais da educação, acreditamos que no LP será implementado estratégias de ações formativas que visam essas reflexões coletivas e possíveis mudanças de atitudes.

A formação continuada compreende dimensões coletivas, organizacionais e profissionais, bem como o repensar do processo pedagógico, dos saberes e valores, e envolve atividades de extensão, grupos de estudos, reuniões pedagógicas, cursos, programas e ações para além da formação mínima exigida ao exercício do magistério na educação básica, tendo como principal finalidade a reflexão sobre a prática educacional e a busca de aperfeiçoamento técnico, pedagógico, ético e político do profissional docente.(BRASIL, Res.02/2015, art. 16, 2015). 
Partindo do respaldo legal sobre a definição do que vem a ser formação continuada, o Laboratório Pedagógico do campus será um local institucionalizado, criado para prestar suporte aos professores, equipe técnico-pedagógica e demais profissionais da educação.

Considerando que na Instituição possui servidores administrativos ligados diretamente ao ensino na função de pedagogos e técnicos em assuntos educacionais e, dentre as suas atribuições estabelecidas na minuta elaboradas em novembro de 2015 consta a “organização, orientação e assessoramento do processo de ensino-aprendizagem", bem como ao setor pedagógico a competência de "propor junto à Direção de Ensino a formação continuada para os docentes por meio de cursos, seminários, oficinas e grupos de trabalho visando a melhoria do processo pedagógico educacional[...]”. Esta proposta de intervenção atende ao previsto e, para isso conta com a organização e efetivação desse trabalho sob a coordenação da equipe pedagógica da Instituição.

Sabemos que a equipe pedagógica de qualquer instituição de ensino tem esse papel de estar prestando esse suporte aos professores, buscando estratégias e subsídios eficazes para a promoção de formação continuada que favoreça uma relação pedagógica significativa, que garanta a melhoria do ensino-aprendizagem.

Embora salienta-se que a equipe pedagógica também não obteve formação específica para atuar na EPT. No entanto, subentende-se que a mesma buscará subsídios formativos e estará coordenando as atividades no LP, fazendo a mediação do processo formativo, sendo também multiplicador, em outros momentos. Logo, será estabelecido uma relação dialética através de trocas de experiências entre professores, equipe pedagógica e outros pesquisadores da área da educação, os quais conjuntamente construirão seus saberes experienciais e vão se constituindo nesse processo formador mútuo. Parafraseando Paulo Freire "quem forma se forma e re-forma ao formar e quem é formado forma-se ao ser formado" (Freire, 2014, p.25).

Segundo Roza (2011), “[...] o exercício da docência é assumir a pesquisa como atitude cotidiana frente aos saberes [...] a criação de espaços de discussão e fomentação[...] para reflexão de inquietações e questões relativas à prática docentes”. Portanto, a formação continuada pensada nesse espaço tem a pretensão de inspirar-se em ideias que conduzam a uma prática crítica e transformadora, referendada em alguns autores citados anteriormente, dentre eles, Tardif (2014) apoiada em sua definição de que "os saberes docentes são plurais e se constituem de amálgama que integram os diferentes saberes". Para ele: 
à pedagogia e desenvolver um saber prático baseado em sua experiencia cotidiana com os alunos (TARDIF, p. 39, 2014).

E em Pimenta (2012), quando diz que “a formação passa sempre pela mobilização de vários tipos de saberes: saberes de uma prática reflexiva, saberes de uma teoria especializada, saberes de uma militância pedagógica".

A criação deste LP tem, na sua concepção original, a proposição de formação para os professores de forma contínua e permanente no próprio ambiente de trabalho, na perspectiva de estar desenvolvendo, não somente encontros esporádicos 'semana pedagógica' que, na percepção dos docentes, se torna insuficiente pelo pouco tempo. Além do mais, vão surgindo situações que emergem do cotidiano de sala de aula que exigem reflexões baseada em dados concretos. Corroboram-se com esta proposta, os dizeres de Imbernón (2010):

\footnotetext{
[...] a formação permanente consiste em algo a mais, que não se limite a atualização à profissional realizada por alguns "especialistas" (que iluminem os professores com seus conhecimentos pedagógicos para que sejam produzidos), mas que, ao contrário passe pela criação de espaços de reflexão e participação nos quais os profissionais da educação faça surgir a teoria subjacente a sua prática com o objetivo de recompô-la, justifica-la ou destruí-la (IMBERNÓN, 2010 p. 118).
}

Neste contexto, Tardif (2014) diz que [...] "a formação dos professores supõe um continuum no qual, durante toda a carreira docente, fases de trabalho devem alternar com fases de formação contínua" (TARDIF, 2014, p.287). E, segundo a pesquisadora Pimenta (2012) "é importante produzir a escola como espaço de trabalho e formação, o que implica gestão democrática e práticas curriculares participativas, propiciando a constituição de redes de formação contínua[...]".

Importante enfatizar que o LP deverá ser criado com a anuência dos professores, gestão de ensino e equipe pedagógica, os quais, a partir dessa proposta prévia de estruturação, exposta na sequência, poderão suprimir situações desnecessárias e ou complementar situações que deixaram de ser contempladas.

\subsection{Proposta de criação do Laboratório Pedagógico No IFPA/CDA}

Finalidade

Criar espaço institucionalizado de formação contínua aos docentes, mediante suporte e apoio aos docentes com estudos, planejamento e reflexão permanente das práticas pedagógicas desenvolvidas no Instituto Federal de Educação, Ciência e Tecnologia do Pará/Campus Conceição do Araguaia. 


\section{Objetivos}

- Institucionalizar um espaço de formação, integração de saberes, reflexão da prática pedagógica, sendo os docentes os principais protagonistas;

- Oferecer capacitações de acordo com as necessidades indicadas pelos próprios professores, equipe pedagógica e ou direção de ensino;

- Favorecer discussões sobre o papel do docente e dos discentes da Educação Profissional e Tecnológica;

- Planejar o processo de ensino-aprendizagem em todas as suas dimensões;

- Propiciar o aprimoramento e a promoção do trabalho pedagógico integrado e interdisciplinar;

- Oportunizar relatos e trocas de experiências entre os pares com o propósito de superação das dificuldades encontradas.

Público Alvo

Será de uso exclusivo dos professores, equipe técnico-pedagógica e demais profissionais da educação que tenham interesse em participar de atividades formativas e de planejamentos que conduzam a melhoria do processo ensino-aprendizagem, de uma forma significativa e flexível.

Parceria

Para implementação das ações formativas no LP será estabelecido parcerias com a Pro-reitoria de ensino, profissionais de outros campi e outras instituições de ensino superior no sentido de fomentar discussões e conhecimentos sobre a EPT, bem como a gestão de ensino e, principalmente, da sala de aula, respaldando no que reza o art. 17 das Diretrizes Curriculares Nacionais para a formação inicial e continuada dos profissionais da educação.

A formação continuada, na forma do artigo 16, deve se dar pela oferta de atividades formativas e cursos de atualização, extensão, aperfeiçoamento, especialização, mestrado e doutorado que agreguem novos saberes e práticas, articulados às políticas e gestão da educação, à área de atuação do profissional e às instituições de educação básica, em suas diferentes etapas e modalidades da educação (Res.02, art. 17, 2015). 
O LP surge em um clima de parceria permanente entre profissionais da educação que estarão estabelecendo trocas de conhecimentos, experiências e saberes que buscam alternativas para o enfretamento da docência na EPT.

\section{Metodologia}

A concepção metodológica do LP está baseada na condução de uma prática pedagógica reflexiva dos docentes da EPT, visando a melhoria da aprendizagem através do aprimoramento e aperfeiçoamento do trabalho educativo desenvolvido em todas as suas dimensões: sala de aula, aulas práticas, visitas técnicas. Partindo dos seguintes princípios:

- A docência requer um permanente processo de formação para o aprimoramento;

- A docência pressupõe diferentes saberes (saberes específicos, pedagógicos e da experiência;

- A prática da reflexão para a produção de conhecimentos sobre o ensino e de mecanismo para o permanente aperfeiçoamento;

- O trabalho interdisciplinar como elo de uma formação integral e significativa. O planejamento deverá ser realizado de forma integrada concentrados por áreas e eixos tecnológicos de cada curso.

Funcionamento - descrição da infraestrutura

O LP funcionará nos três turnos ininterruptos (das $8 \mathrm{~h}$ às $22 \mathrm{~h}$ ) e será em um local estratégico, numa sala ampla, climatizada, arejada, medindo 10,55 por $8,30\left(87,56 \mathrm{~m}^{2}\right)$. O espaço interno do LP será aberto, porém contendo vários ambientes interligados que serão organizados com o propósito de acolhimento, oferecendo um certo conforto, estimulando e motivando a participação diária dos professores. Como um esboço preliminar foi construído um Layout (Figura 3), na sequência, de como ficará esse ambiente internamente: 


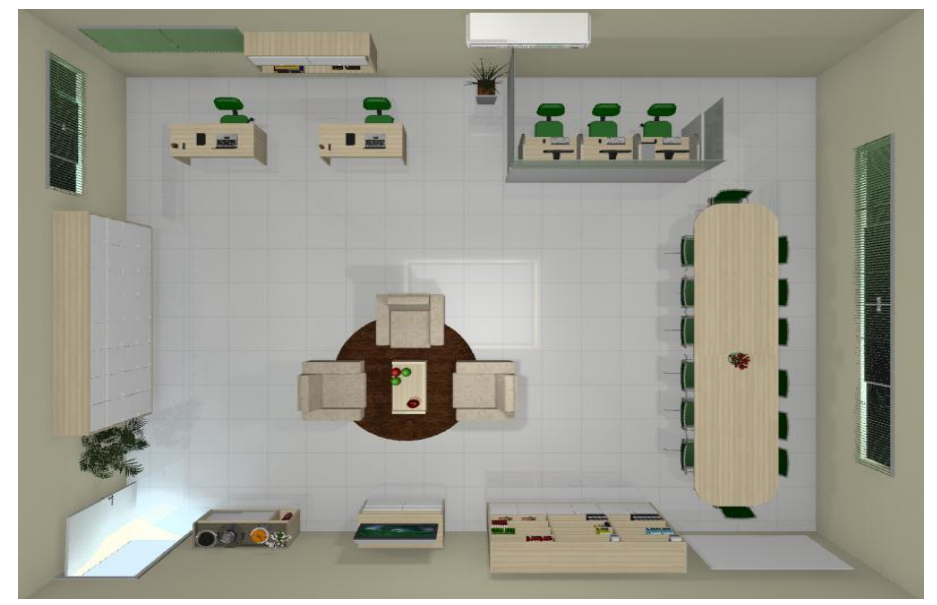

Fonte: Layout criado para o Laboratório Pedagógico, 2016.

Nesse ambiente, será disposto um sofá aconchegante sobre um tapete, com mesa de centro, arranjos decorativos, e um móvel, tipo carrinho bar, onde estarão dispostos os produtos para coffee break. No LP por ser um espaço específico dos professores, será disponibilizado armários personalizados com chave para cada professor guardar seus pertences. Haverá também uma estante com livros pedagógicos que tratam da formação docente, Constituição Federal, LDB, catálogos dos cursos técnicos e de tecnologia, documentos institucionais (PDI, PDC, PPP, PPCs, Organização Didática) revistas, periódicos, DVDs entre outros, todos expostos para ser manuseados pelos professores diariamente ou quando precisarem.

Dentro desse espaço também será criado a sala de TV com DVD para que os professores possam assistir documentários, filmes, palestras, web conferência e etc.

Existirá na composição desse ambiente, uma mesa grande de 6 (seis) metros com cadeiras e uma tela de projeção com pedestal e data show, de forma a garantir uma integração maior dos professores nos momentos de formação e planejamento coletivo. Sabemos que a maioria dos docentes carregam e utilizam-se dos seus computadores pessoais, mas ainda assim, será disponibilizado um local da sala que comporte (03) três computadores, conectados com internet e uma impressora.

Operacionalização da Formação no Laboratório Pedagógico

Em se tratando do LP, o qual tem na essência de sua criação, a finalidade de formação continuada dos professores do IFPA/CDA, buscou-se preliminarmente definir um 
esboço dessa formação, porém, será consolidado esta proposta de operacionalização, a partir das discussões com o coletivo da Instituição.

Assim, inicialmente além de oportunizar o planejamento interdisciplinar, disponibilizar de forma progressiva uma diversidade de cursos de capacitação e aperfeiçoamento, debates de temáticas relacionadas a formação pedagógica, ou seja, atividades formativas para o aprimoramento, podendo chegar até ao nível de especialização, com carga horária de acordo com cada atividade com base no art. 17 da Res. 02/2015 que define as diretrizes para formação continuada de professores e ou Legislações vigentes

O LP ficará na responsabilidade da equipe pedagógica que estará disponível no local para dar suporte aos professores nos três turnos de funcionamento, os quais definirão juntamente com os professores e direção de ensino a melhor operacionalização dos cursos, duração, carga horária, período de realização, certificação didático-pedagógica, de acordo com as demandas e necessidades formativas.

Desta forma, acreditamos que se trata de uma importante ação formativa que, a partir de referenciais teóricos, das práticas pedagógicas em desenvolvimento, serão realizadas reflexões que conduzirão a uma prática educativo-crítica do processo ensino-aprendizagem, o qual estará sendo reforçado coletivamente para que o torne efetivamente eficaz e eficiente na formação dos profissionais formados pela Instituição de educação profissionalizante com as exigências impostas nesta sociedade contemporânea.

Considerando que os dados desta pesquisa revelaram que o planejamento interdisciplinar, tem acontecido, esporadicamente através de uma única disciplina denominada de Projeto integrador, mas, no entanto, a realidade nos mostra que não são todos os cursos que tem esta disciplina em sua estrutura curricular, ou seja, não se trata de uma realidade em todos os eixos tecnológicos, não está estabelecido como uma prática comum na Instituição, fazer uma ação pensada na coletividade e com envolvimento, será o grande desafio nesse LP e, consequentemente, ganhará todos: Instituição/professores/alunos e sociedade.

Portanto, além de superar as dificuldades na condução do processo educativo na EPT, as atividades desenvolvidas no LP, serão computadas suas Cargas horárias de acordo com participação, envolvimento e desempenho individual de cada professor, bem como serão certificadas e contará para comprovação e contará pontos para o Reconhecimento de Saberes e Competências-RSC, como política de valorização do trabalho docente realizado.

Como indicação dos cursos de capacitação, complementação pedagógica e aperfeiçoamento que visem o aprimoramento dos docentes, definiu-se preliminarmente eixos 
temáticos, no entanto, poderão serem mantidos, reformulados, substituídos, complementados quando da discussão com a coletividade na Instituição. A saber:

- Docência na Educação Profissional e Tecnológica (serão discutidos sobre a organização, legislação e gestão da Educação Profissional e Tecnológica; Educação Profissional e o mercado de trabalho, aspectos da docência para a EPT entre outros);

- Psicologia da Aprendizagem e do desenvolvimento (serão discutidos aspectos do funcionamento da mente humana para aquisição do conhecimento, como o ser humano aprende e demais assuntos correlatos como ética, relação interpessoal entre outros);

- Gestão da Sala de Aula (serão discutidos os desafios e condições de cunho pedagógico para gerir a sala de aula de forma efetiva e garantir a qualidade do ensino bem como questões pertinentes da relação Professor-aluno para uma aprendizagem efetiva e significativa);

- Planejamento e Didática na EPT (serão abordadas sobre as tendências pedagógicas para que o professor relacione com sua prática pedagógica e procure fundamentar e referenciar na concepção que melhor se adapta às necessidades educacionais atuais, ou seja, diferentes abordagens no oficio da docência para a efetiva transposição didática dos conteúdos ministrados, importância do planejamento no trabalho pedagógico bem como orientações para elaboração desse Planejamento de ensino e de metodologias ativas de ensino e aprendizagens);

- Avaliação da Aprendizagem; (serão discutidos a definição pedagógica do termo avaliação da aprendizagem e suas implicações para melhoria do processo ensinoaprendizagem);

- Tecnologias da Informação e Comunicação (capacitar os professores, através de oficinas para operacionalização das TICs em favor do processo ensino-aprendizagem);

- Educação Inclusiva e Diversidade (serão abordados sobre as Necessidades Específicas considerando as condições das pessoas com deficiência e a diversidade cultural);

- Eixos Tecnológicos dos Cursos Técnicos e de Tecnologia (será oferecido em forma de oficinas com abordagens teóricas e práticas, temáticas para complementar e atualizar os conhecimentos específicos por área de formação e ou atuação);

- Registros e acompanhamento do desempenho dos alunos (será oportunizado aos docentes uma oficina sobre a importância correta e diária da utilização dos principais instrumentos institucionais para os registros e acompanhamento do desempenho dos alunos, entre outras atividades correlatas). 


\section{CONSIDERAÇÕES FINAIS}

Antes de tecer nossas considerações, porém, se faz pertinente reconhecer que como são análises subjetivas, de interpretações possíveis, deixa-se em aberto para outras reflexões complementares diante da realidade apresentada.

Neste momento, é preciso retomar a problematização proposta para realização desse estudo. Assim, se propôs a identificar em que medida a formação do professor de Educação Profissional e Tecnológica influencia no processo ensino-aprendizagem no âmbito dos cursos técnicos subsequentes do IFPA-Campus Conceição do Araguaia. Para isso, traçaram-se alguns objetivos que conduzissem esse processo investigativo.

Em relação ao objetivo de construir o perfil da formação dos docentes do IFPA/CDA, a investigação foi mais além. Realizou um levantamento mais detalhado descrevendo o perfil e itinerário formativo dos 36 (trinta e seis) professores que compõem o quadro docente, demonstrado nos capítulos anteriores. Portanto, verificamos a predominância dos professores com formação inicial a nível de bacharelado, correspondente a $81 \%$ do total de docentes. Todavia, a maioria deles ampliaram sua formação e realizaram cursos a nível de pós-graduação (lato e stricto sensu) e ou estão cursando. No entanto, constatamos, em um número pequeno, encontramos docentes que estão apenas com a formação inicial, ainda não fizeram nenhuma especialização. Em relação ao perfil de formação para ingresso na Instituição, verificamos que, por força legal, são exigidas nos editais de concursos apenas formação mínima, a nível de graduação por área de conhecimento, ou seja, formação em nível de bacharelado e engenharias, não exigindo para ingresso nenhuma formação para a docência, fato percebido pelo quantitativo de bacharéis na Instituição. Esse tem sido um dos maiores problemas apontados pelos próprios docentes, da não formação para assumir a docência, principalmente para a EPT. Nesse sentido, este estudo sinaliza uma possibilidade de mudança, pois o clamor vem dos próprios professores.

Para reverter esta realidade, em âmbito nacional, só por meio de uma política pública consolidada de formação para os docentes que irão atuar na EPT que poderão ser implementadas através de parcerias entre as faculdades de educação na oferta de curso para a docência em EPT. Outra possibilidade com mais chance de se concretizar, seria as faculdades de educação, agregarem no currículo de seus cursos, uma carga horária que retratassem aspectos epistemológicos desta modalidade da educação e, consequente, os saberes docentes. 
Enquanto isso, não se efetive, acreditamos que as instituições possuem autonomia para rever de forma mais rigorosa as cláusulas contidas nos editais de concurso, a fazer exigências e estabelecendo o mesmo peso àqueles candidatos com formação e experiência docente seguido de experiência profissional na área de conhecimento técnico e ou tecnológico assim como tem acontecido com as pontuações designadas a quem tenha especializações stricto sensu, para que estas não sobreponha em termos de pontuação às anteriores.

A situação desvelada na realidade da maioria dos IFs, em relação a não formação para docência, instiga a tomada de decisão no sentido de estar proporcionando formações continuadas, haja vista ser uma profissão que necessita para seu fazer pedagógico estar subsidiada em diretrizes e reflexões que deem coerência e fundamentação ao processo educativo. Tanto que, alguns docentes, por iniciativa própria, sentindo esta lacuna em sua formação, devido a sua atuação docente, buscaram complementar sua formação com o objetivo principal de melhorar sua atuação docente.

Diante desse contexto, nos faz afirmar, sem medo de errar que, a formação docente influencia no processo ensino-aprendizagem na medida em que ao professor exige-se diferenciados saberes e a questão da gestão da sala de aula perpassa por diferentes dimensões, desde a questão da relação harmoniosa e produtiva estabelecida entre os alunos, entre seus pares, como também, essencialmente, para construção do processo educativo, o professor precisa realizar a transposição didática que significa transformar o conhecimento científico, modificando-o, de forma a torná-lo 'ensinável' com condições de ser aprendido e, sem sombra de dúvida, a ausência de formação pedagógica é o " $x$ " da questão.

O professor cria relações e condições didáticas para que o aluno aprenda, disso, se extrai que, apenas o domínio do conteúdo não seja suficiente para a docência, nem tampouco para a promoção do aprendizado, refutando-se aquela máxima de dizer que 'para ensinar, basta saber' não se trata simplesmente disso. Parafraseando o grande educador Paulo Freire (1921-1997), "Não basta saber ler que Eva viu a uva. É preciso compreender qual a posição que Eva ocupa no seu contexto social, quem trabalha para produzir a uva e quem lucra com esse trabalho". Portanto, o papel do professor se dá num processo mais dinâmico, ativo e crítico, cabe a ele realizar esta mediação pedagógica, estabelecendo a diferença entre ensinar práticas e ensinar os saberes sobre essas práticas. Para isso, devem introduzir em suas aulas, atividades que aproximam do contexto social e das relações do trabalho, realizar a articulação entre teorias e atividades práticas. Esta frase, inclusive, leva a reflexão do perfil docente para a educação profissional. "Entende-se que se trata de um profissional que sabe o que, como e 
por que fazer e aprendeu a ensinar, para desenvolver idônea e adequadamente outros profissionais" (MACHADO, 2008 p. 11).

Por isso, a formação para docência, se apresenta como uma certa necessidade, uma vez que qualquer professor quando entra em uma sala de aula, necessariamente, conscientemente ou não, a sua prática pedagógica pressupõe uma certa compreensão de mundo, do ser humano, do processo educativo e, hipoteticamente, quando não possui a compreensão do processo educativo, começam a surgir os problemas como: insegurança do professor e ou resistência em planejar as aulas; processo ensino-aprendizagem meio que descontextualizado e incompreensível tanto pelo professor quanto pelo aluno.

Enfim, essa ausência de formação, a princípio, poderá levá-los a ter dificuldades em estabelecer diretrizes e critérios para organizar o fazer pedagógico. Por outro lado, esses saberes podem ser construídos, agregados no decorrer de sua prática pedagógica reflexiva.

A partir do mapeamento geral do perfil docente do IFPA, coletamos informações dos 06 (seis) docentes que fazem parte da amostra, sendo 03 (três) com formação inicial a nível de licenciatura e 03 (três) com formação a nível de bacharelado. Na caracterização desse grupo, percebemos que todos tinham dedicação exclusiva. No entanto, todos eles exercem concomitantemente outras funções administrativas. Notamos, o reconhecimento de um certo comprometimento em relação a qualidade do trabalho realizado quer em sala de aula, quer na função administrativa justificada pelo fator tempo e envolvimento com uma ou outra atividade, não havendo possibilidade de haver uma dedicação melhor e ou proposição de mudanças em termos de uma ação pensada qualitativamente.

Pelo depoimento de um dos docentes percebe-se que as coisas vão acontecendo, quase mecanicamente, ligada no automático. Sem tempo de um planejamento mais detalhado das ações a serem desenvolvidas, principalmente na função administrativa que se restringe mais em receber e responder documentos, aspectos burocráticos do cargo.

Em relação ao objetivo de identificar a percepção dos docentes sobre a sua formação e as implicações na prática pedagógica, podemos afirmar com base nos depoimentos que, sem dúvida, os ensinamentos obtidos na formação inicial, somados com os saberes da vivênciaexperiência laboral na área de atuação, na formação continuada, acrescentando-se a isso a experiência em sala de aula, interação com seus pares, estar bem informado e atualizado são saberes que foram apontados como de total influência nas práticas pedagógicas.

Percebemos no depoimento dos docentes dos dois perfis, situações pontuais que podem estar inviabilizando sistematicamente sua prática pedagógica, tais como: ausência de 
uma formação para docência na EPT; disponibilidade de maior tempo de planejamento para suas atividades de forma interdisciplinar, estruturação dos laboratórios dos cursos, aquisição de acervo bibliotecário no nível do curso, materiais e equipamentos necessários às atividades práticas e apoio logístico para realização de visitas técnicas, são aspectos que tem repercussão diretamente no aprendizado do aluno.

Quanto a percepção dos discentes sobre o processo ensino-aprendizagem. Importante salientar quem são esses alunos. Os dados revelam que os alunos da instituição se constituem como um público bem diversificado, onde se tem alunos cursando curso técnico, mas que já realizaram uma graduação e alunos que estão cursando concomitantemente uma graduação em outra instituição e um público menor cursando somente o ensino técnico.

Portanto, eis mais um motivo que a formação do professor influencia no processo educativo, pois o docente, deverá em sua prática pedagógica, considerar os perfis diferenciados de alunos, munir-se conscientemente de metodologias, estratégias, analogias, direcionados aos dois perfis. Nem no nível baixo, simples, que desmotive quem já passou por uma academia, nem em ritmo acelerado que não corresponda as expectativas e ritmos diferenciados na aquisição e construção do conhecimento. Nesse contexto, a sensibilidade e maturidade pedagógica do docente fará toda a diferença, do contrário, a não adequação poderá contribuir para ampliação do quadro de evasão.

Sendo uma Instituição de Educação Profissional, o resultado não poderia ser diferente, predominaram-se os alunos que buscam a possibilidade de obter um curso técnico profissionalizante para inserção no mercado de trabalho. Nesse sentido, reiteramos o importante papel da instituição, a necessidade de investimento em condições adequadas de infraestrutura, materiais didáticos, professores bem qualificados, entre outros, conforme reiteradamente mencionados no tratamento dos dados da pesquisa com os alunos e docentes.

Os pressupostos abordados, até então, nos fazem reiterar a comprovação de sérias consequências à profissionalização docente nessa modalidade da educação, percebida pela ausência de políticas públicas para a formação docente para a EPT. Constatamos que o Estado não assume sua obrigação e deixa sob a responsabilidade de iniciativas individuais das Instituições a oferta de cursos de Licenciaturas ou de Programas complementares de formação pedagógica que acabam ficando a mercê da vontade política e pedagógica de seus gestores.

Assim, diante dos resultados apresentados neste estudo, como proposta de intervenção, propomos ao gestor, a criação de um Laboratório Pedagógico, o qual será um um espaço institucionalizado de formação docente e integração dos saberes, com a finalidade 
de oferecer momentos de formação continuada, mediante suporte e apoio aos docentes com estudos, reflexões e planejamentos permanentes das práticas pedagógicas desenvolvidas no Instituto Federal de Educação, Ciência e Tecnologia /Campus Conceição do Araguaia de forma a propiciar uma ação pensada interdisciplinar e coletivamente mais eficiente.

Finalizando, espera-se que este estudo possa suscitar maiores debates e instigue outras pesquisas que possam evidenciar a importância da formação inicial e continuada para a docência na EPT e que, se não o Estado, os gestores das Instituições assumam essa obrigação, como forma de legitimar um ensino de qualidade e valorização da docência, enquanto aspectos de grande influência no processo ensino-aprendizagem, imbricados no compromisso e transformação social. 


\section{REFERÊNCIAS}

ALVES, Z.M.M.B, SILVA, M.H G.F. D. Análise Qualitativa de Dados: uma proposta. Paidéia, FFCLRP -USP, Rib. Preto, 2, Fev/Jul,1992. Disponível em <http://www.scielo.br/scielo.php?script=sci_arttext\&pid=S0103-863X1992000200007 Acesso em Jan de 2016.

ANDRÉ, M. O que é um estudo de caso qualitativo em educação? Revista da FAEEBA Educação e Contemporaneidade, Salvador, v. 22, n. 40, p. 95-103, dez.2013. Acesso em set. de 2015. Disponível em http://www.revistas.uneb.br/index.php/faeeba/article/viewFile/753/526

ARAÚJO, R.M.de L. Formação de docentes para a educação profissional e tecnológica: por uma pedagogia integradora da educação profissional. Trabalho \& Educação- vol.17, $\mathrm{n}^{\circ} 2$; Maio/ago, 2008.

AZEVEDO, Fernando. A cultura brasileira. $4^{\circ}$ ed., Universidade de Brasília-UnB, 1963.

BARDIN, L. Análise de Conteúdo/Laurence Bardin; tradução Luís Antero Reto, Augusto Pinheiro. São Paulo: Edições 70, 2011.

BRASIL. Presidência da República. Lei 5.692, de 11 de agosto de 1971. Fixa diretrizes e bases para o ensino de $1^{\circ}$ e $2^{\circ}$ graus [...]. Disponível em: $<$ http://www.planalto.gov.br/ccivil_03/leis/15692.htm>. Acesso em nov. de 2014.

BRASIL. Presidência da República. Portaria 432/71, de 19 de julho de 1971. Fixa Normas para organização curricular do Esquema I e do Esquema II. Disponível em http://siau.edunet.sp.gov.br/ItemLise/arquivos/notas/port432_71.htm. Acesso em nov de 2014

BRASIL. Presidência da República. Lei n ${ }^{\circ}$ 9.394, de 20 de dezembro de 1996. Estabelece as diretrizes e bases da educação nacional. Disponível em:

<http://www.planalto.gov.br/ccivil_03/Leis/L9394.htm>. Acesso em out. de 2014.

BRASIL. Decreto $\mathbf{N}^{\circ} \mathbf{2 . 2 0 8}$ de 17 de abril de 1997. Regulamenta o $\S 2^{\circ}$ do art. 36 e os arts. 39 a 42 da Lei Federal No 9.394/96, que estabelece as Diretrizes e Bases da Educação Nacional. 1997. Disponível em: <http://www.planalto.gov.br/ccivil_03/Leis/L9394.htm>. Acesso em out. de 2014.

BRASIL. Parecer CNE/CEB no 37, de 4 de setembro de 2002. Consulta sobre formação de professores para a Educação Profissional de Nível Técnico.

BRASIL. Presidência da República. Decreto no 5.154 de 23 de julho de 2004. Regulamenta o $\S 2^{\circ}$ do art. 36 e os arts. 39 a 41 da Lei ${ }^{\circ}$ 9.394, de 20 de dezembro de 1996, que estabelece as diretrizes e bases da educação nacional, e dá outras providências. Disponível em http://www.planalto.gov.br/ccivil_03/_ato2004-:<2006/2004/Decreto/D5154.htm>. Acesso em nov. de 2014. 
BRASIL. Lei 11.741, de 16 de julho de 2008. Altera dispositivos da Lei no 9.394, de 20 de dezembro de 1996 [...]. Disponível em:〈http://www.planalto.gov.br>. Acesso em nov. de 2014.

BRASIL. Lei 11.892 de 29 de dezembro de 2008. Institui a Rede Federal de Educação Profissional, científica e Tecnológica, cria os Institutos Federais de Educação, Ciência e Tecnologia. Brasília/DF

BRASIL. Lei 13.055, de 25 de junho de 2014. Aprova o Plano Nacional de Educação PNE [...]. Disponível em:< http://www.planalto.gov.br/ccivil_03/_Ato20112014/2014/Lei/L13005.htm>. Acesso em nov. de 2014.

IFPA. Edital no 04 de 13 de maio de 2015, torna pública a abertura das inscrições para o Concurso Público para provimento de vagas de professores da Carreira do Ensino Básico, Técnico e Tecnológico - EBTT no IFPA.

IFPA. Plano de Desenvolvimento Institucional dos Institutos Federais de Educação, Ciência e Tecnologia, Belém, 2009-2013.

IFPA. Plano de Desenvolvimento Institucional dos Institutos Federais de Educação, Ciência e Tecnologia, Belém, 2014-2018.

IFPA. Organização Didática do Desenvolvimento do Ensino do Instituto Federal de Educação, Ciência e Tecnologia, Belém, revisada em 2010.

CAMPOLINA, L. O. de. Inovação Educativa e Subjetividade: a configuração da dimensão histórico-subjetiva implicada em um projeto inovador. Tese de Doutorado. Universidade de Brasília. Faculdade de Educação. 2012. Disponível em:

<http://repositorio.unb.br/bitstream/10482/10760/1/2012_LucianaDeOliveiraCampolina.pdf> Acesso em: 15 jan. 2016.

CAMPOLINA, L.O., MITJÁNS MARTÍNEZ, A. Fatores Favoráveis à Inovação: Estudo de Caso em uma Organização Escolar. Revista Psicologia: Organizações e trabalho, 13(3) set-dez 2013, pp.325-338, 2013.

CARVALHO, O.; SOUSA F. Formação do Docente da Educação Profissional e

Tecnológica no Brasil: um diálogo com as Faculdades de Educação e o curso de Pedagogia. Educ. Soc., Campinas, v. 35, nº. 128, p. 629-982, jul.-set. 2014.

CARVALHO, O. F. Educação e formação profissional-trabalho e tempo livre. Editora Plano, 2003. 176p.

CASTANHA, André Paulo (2007). O Ato Adicional de 1834 e a educação elementar no Império: descentralização ou centralização? Tese (Doutorado), UFSCar, São Carlos.

CHEVALLARD, Yves. La transposición Didáctica: del saber sabio al saber enseñado. Traducción: Claudia Gilman;1991.

CHIZZOTTI, Antonio. Pesquisa em ciências humanas e sociais. 8. Ed. - São Paulo: Cortez, 2006 - (Biblioteca da Educação. Série 1. Escola; v. 16) 
COELHO, Ildeu M. Formação do educador: dever do estado, tarefa da Universidade. In: Formação do educador. São Paulo: Editora UNESP, v. 1, 1996.

COSTA, Maria Adélia. Política de formação de professores para a educação profissional e tecnológica: cenários contemporâneos. Tese (Doutorado em Educação), Centro de Educação/UFU, 2012.

CRESWELL, J. W. Projeto de pesquisa: métodos qualitativo, quantitativo e misto. 3. ed. Porto Alegre: Artmed, 2010.

CRESWELL, J. W. CLARK Vicki L.P. Pesquisa de Métodos Mistos. 2. ed. Porto Alegre: Penso, 2013.

DELORS, Jacques (presidente). Relatório para UNESCO da Comissão Internacional sobre Educação para o século XXI: Educação: Um tesouro a descobrir. Brasília: UNESCO/Faber-Castell,2010.

FILHO, R. A. P. Parecer técnico ao se referir aos cursos do Esquema II, MEC, 1998. Disponibilizado site do órgão federal.

FERRETI, C. J. Educação profissional. In: OLIVEIRA, D. A.; DUARTE, A. M. C.; VIEIRA, L. M. F. Dicionário: trabalho, profissão e condição docente. Belo Horizonte: UFMG/Faculdade de Educação, 2010. CDROM

FRANCO, M. L. P. B. Análise do Conteúdo. Brasília, 4ª edição: Líber Livro Editora, 96p. (série pesquisa); v.6), 2012

FREIRE, P. Educação como prática da liberdade. 19ª ed. Rio de Janeiro: Paz e Terra, 1989.

FREIRE, P. Pedagogia da Autonomia: saberes necessários à prática educativa. $48^{\mathrm{a}}$ ed. Rio de Janeiro: Paz e Terra, 2014.

GATTI, Bernadete A. Prefácio. In: KRONBAUER, Selenir C. G., SIMIONATO Margareth F. (orgs) - Formação de professores: abordagens contemporâneas. 3a. ed. São Paulo: Paulinas, 2011.

GIL, A.C. Métodos e técnicas de pesquisa social. São Paulo: Atlas, 1994.

GIL, A.C. Como elaborar projetos de pesquisa. 5a ed. São Paulo: Atlas; 2010.

GRAMSCI, Antonio. Os intelectuais e a organização da cultura. Rio de Janeiro: Civilização Brasileira, 1968.

IMBERNÓN, F. Formação docente e profissional: formar-se para a mudança e a incerteza. $8^{\mathrm{a}}$ ed. São Paulo; Cortez, 2010.

KUENZER, Acacia Z.O trabalho como princípio educativo. Caderno de Pesquisas, São Paulo (68): 21-28, fev. 1989 
LEÃO, D.M.M. Paradigmas Contemporâneos de educação: escola tradicional e escola construtivista. Cadernos de Pesquisa, nº 107, p. 187-206, julho/1999.

LIBANEO, J.C. O Dualismo perverso da escola pública brasileira: escola do conhecimento para os ricos, escola do acolhimento social para os pobres. Educação e Pesquisa, São Paulo, v. 38, n. 1, p. 13-28, 2012.

LIBÂNEO, José Carlos. Didática. São Paulo: Cortez Editora, 1994.

LOPES, A. O. Planejamento do ensino numa perspectiva crítica de educação. In: VEIGA, Ilma Passos Alcântara (Cood). Repensando a didática. Campinas: Papirus, 1991.

LOURENÇO FILHO, M. B. Introdução ao estudo da Escola Nova. São Paulo, Melhoramentos, 1978.

LÜDKE, M. e ANDRÉ, M. Pesquisa em educação: abordagens qualitativas. São Paulo: EPU, p. 99,1986.

MACHADO, Lucília Regina de Souza. Diferenciais inovadores na formação de professore para educação profissional. Revista Brasileira da Educação Profissional e Tecnológica, v.1, p. 8-22, 2008.

MARCONI, M. e LAKATOS E. Metodologia Científica. 5a ed. São Paulo: Atlas; 2011.

MANACORDA, Mário A. O princípio educativo em Gramsci. Porto Alegre: Artes Médicas, 1990.

MANFREDI, Silvia Maria. Educação Profissional no Brasil. São Paulo: Cortez, 2002 (col. Docência em Formação - Educação Profissional).

MEIRIEU, Philippe. Aprender... sim, mas como? Porto Alegre, Artmed,1998.

MELLO, Guiomar Namo de. Magistério de $\mathbf{1}^{\mathbf{0}}$ grau: da competência técnica ao compromisso político. São Paulo: Cortez, 1985.

MENEZES, Ebenezer Takuno de; SANTOS, Thais Helena dos."Bacharelado" (verbete). Dicionário Interativo da Educação Brasileira - EducaBrasil. São Paulo: Midiamix Editora, 2002, http://www.educabrasil.com.br/eb/dic/dicionario.asp?id=141, visitado em $5 / 10 / 2015$.

MINAYO. M. C. S. Análise qualitativa: teoria, passos e fidedignidade, 2011.

MORIN, Edgar. Os sete saberes necessários à educação do futuro/Tradução de Catarina Eleonora F. da Silva e Juanne Sawaya; 2.ed. ver-São Paulo: Cortez; Brasília,DF: UNESCO, 2011.

NÓVOA, Antônio. Três bases para um novo modelo de formação, ed. 027, agosto/setembro 2013. Disponível em: <http://gestaoescolar.abril.com.br/.../tres-basesnovo... >. Acesso em: 08 de outubro de 2015. 
OLIVEIRA, M. R. N. S. Formação e profissionalização dos professores do ensino técnico. In: ARANHA, Antônio (org); 2005.

PETEROSSI, Helena Gemignani. Formação de professores para o ensino técnico. São Paulo: Edições Loyola, 1994.

PONTES, A. P. F.S. Professores da Educação Profissional e Tecnológica: alguns aspectos de sua profissionalização e formação. (2014) Disponível em http://www.anpae.org.br/IBERO_AMERICANO_IV/GT4/GT4_Comunicacao/AnaPaulaFurta doSoaresPontes_GT4_integral.pdf. Acesso 20 Nov 2014

PEREIRA, A. C. A formação de professores e a capacitação de trabalhadores da educação profissional e tecnológica, 2009. Disponível em < http://portal.mec.gov.br/setec/arquivos/pdf/lic_ept.pdf >. Acesso em: 20 nov 2014

PEREIRA, J. E. D. As licenciaturas e as novas políticas educacionais para a formação docente. In: Educação \& Sociedade. Revista Quadrimestral de Ciência da Educação. Campinas: CEDES, Ano 20, n.68, p.109-125, Dezembro, 1999.

PIMENTA, S.G. Formação de professores: identidade e saberes da docência. In:(Org.). Saberes pedagógicos e atividade docente. São Paulo: Cortez, 1999.

PIMENTA, S.G. Saberes pedagógicos e atividade docente. (Org.) São Paulo: Cortez, 2012.

REHEM, C.M. Perfil e Formação do Professor de Educação Profissional Técnica. São Paulo: Editora SENAC, 2009.

ROZA, J. P. da. Desafios da docência: algumas reflexões sobre a possibilidade de uma gestão pedagógica da pesquisa. In: Kronbauer \& Simionato (orgs.) Formação de professores: abordagens contemporâneas, $3^{\text {a }}$ ed. São Paulo: Paulinas, 2011.

RIOS, T.A. Compreender e ensinar: por uma docência da melhor qualidade. $8^{a}$ Ed. São Paulo: Cortez, 2010

SANTOS, L. L. de C. P. Formação Docente: questões Atuais. In: I Congresso IberoBrasileiro, VI Congresso Luso-Brasileiro, IV Congresso do Fórum Português, 2010, Elvas/Cáceres/Méridas. Cadernos ANPAE. Lisboa: FPAE-PT/FEAE-ES/ANPAE-BR, 2010. p. 1-12. >Acesso em 28/01/2015. Disponível em: <http://www.anpae.org.br/iberolusobrasileiro2010/cdrom/62.pdf

SAVIANI, D. Escola e Democracia. São Paulo, Cortez, 1985.

SAVIANI, Dermeval (2011). "Plano Nacional de Educação, a questão Federativa e os municípios: o regime de colaboração e as perspectivas da educação brasileira. Conferência proferida na Seção de Abertura do $6^{\circ}$ Fórum Internacional de Educação da Região Metropolitana de Campinas e $1^{\circ}$ Fórum de Educação de Paulínia em 29 de agosto de 2011. 
TARDIF, M. Os professores enquanto sujeitos do conhecimento: subjetividade, prática e saberes no magistério. In: CANDAU, Vera Maria (Org.). Didática, Currículo e saberes escolares. Rio de Janeiro: DP\&A, 2000.

TARDIF M. \&. LESSARD C. O trabalho Docente; Elementos para uma teoria da docência como profissão de interações humanas. $6^{\mathrm{a}}$ ed. Trad. De João Batista Kreuch. Petrópolis, Vozes, 2011

VASCONCELLOS, C.S. Avaliação: Concepção dialética do processo de avaliação escolar $11^{a}$ ed. São Paulo: Libertad, 2000.

VASCONCELLOS, C.S. Competência Docente na Perspectiva de Paulo Freire. Revista de Educação AEC n. 143 (abril-junho de 2007) p. 66-78, 2012.

VASCONCELLOS, C.S. Desafio da qualidade da educação: gestão da sala de aula $6^{\text {a }}$ ed. São Paulo: Libertad, 2002

VEIGA I. P. A. \& D’Ávila C. Profissão Docente: Novos sentidos, Novas perspectivas. Campinas. São Paulo, 2008-Coleção Magistério: Formação e Trabalho Pedagógico).

VIDAL D. Gonçalves. 80 anos do Manifesto dos Pioneiros da Educação Nova: questões para debate. Educ. Pesquisa, São Paulo, v. 39, n. 3, p. 577-588, jul./set. 2013. Disponível em http://www.scielo.br/pdf/ep/v39n3/aop1177.pdf. Acesso em 12 de dez de 2015.

VYGOTSKY, L. S. A formação social da mente. São Paulo: Martins Fontes, 1991.

YOU TUBE, Rubem Alves - A Escola Ideal e o papel do professor. Revista digital. brasil.gov.br. Disponível em 〈https://www.youtube.com/watch?v=qjyNv42g2XU>. Acesso em: 04 nov de 2015. 


\section{Apêndice A - Carta ao Diretor Geral solicitando autorização e apoio para realização da pesquisa no Campus.}

Prezado (a) Diretor do Instituto Federal de Educação, Ciência e Tecnologia do Pará-Campus Conceição do Araguaia,

Na condição de servidora deste Campus e mestranda do Mestrado Profissional em Políticas Públicas e Gestão da Educação Profissional e Tecnológica pela UnB, matrícula nº 13/0178756, venho através deste, solicitar a Vossa Senhoria autorização e apoio para realização da pesquisa de mestrado sobre a Docência na EPT-Educação Profissional e Tecnológica, a qual tem como finalidade analisar a formação docente e sua influência no processo ensino-aprendizagem dos alunos do curso técnico subsequente no IFPA-Campus Conceição do Araguaia. Para tanto, este estudo traçou alguns objetivos específicos:

- Construir o perfil de formação dos docentes do IFPA/CDA;

- Identificar a percepção dos docentes sobre a sua formação e suas implicações na prática pedagógica;

- Identificar a percepção dos discentes sobre o processo ensino-aprendizagem;

- Analisar as repercussões das práticas pedagógicas no processo ensino-aprendizagem, conforme o perfil de formação docente;

- Elaborar um produto técnico como proposta de intervenção aos resultados da pesquisa.

Para a realização desta pesquisa, serão utilizados procedimentos próprios da pesquisa de abordagem qualitativa, em sua modalidade exploratório-descritiva e documental, através de leituras e investigação de documentos institucionais (PDI, PDC, PPI, PPP, entre outros), bem como observação e entrevistas semiestruturadas com 06(seis) professores e também será feito pesquisa junto a alguns alunos, quantidade a ser definida após levantamento dos dados de alunos frequentes.

Fica assegurado que as informações coletadas serão utilizadas para fins exclusivamente acadêmicos, evitando quaisquer atividades que causem prejuízo à Instituição e aos participantes envolvidos nesta pesquisa.

Atenciosamente,

Rosilândia Ferreira de Aguiar

Mestranda/Pesquisadora 


\section{Apêndice B- Carta ao Docente convidando-o a participar da pesquisa e conceder a entrevista.}

Prezado (a) docente,

Na condição de mestranda em Políticas Públicas e Gestão da Educação Profissional e Tecnológica pela UnB, matrícula $n^{\circ} 13 / 0178756$, estamos dando continuidade aos nossos estudos sobre a docência na EPT-Educação Profissional e Tecnológica. Desta forma, gostaria de convidá-lo (a) a colaborar de forma voluntária com esta pesquisa, nos concedendo uma entrevista, a qual tem como finalidade analisar a percepção dos participantes sobre a formação docente e suas implicações no processo ensino-aprendizagem dos alunos dos cursos técnicos no IFPA-Campus Conceição do Araguaia. Para isso, será criado um roteiro com perguntas específicas sobre o assunto.

As respostas a essas questões não terão qualquer interferência ou questionamento de minha parte. A priori, sua participação poderá proporcionar um maior conhecimento sobre o assunto que está sendo pesquisado, o que poderá beneficiá-lo futuramente assim como outros profissionais a ingressar nesta modalidade de ensino, a EPT. Não existirão despesas ou compensações pessoais para nenhum participante em qualquer fase do estudo, e não há compensação financeira relacionada à sua participação.

Você pode, a qualquer momento, obter qualquer esclarecimento sobre o estudo, bem como desistir de participar do mesmo, sem qualquer prejuízo a você.

Você tem a garantia de que as informações obtidas por meio do questionário e da entrevista serão analisadas pela pesquisadora e não será divulgada, em hipótese alguma, a identificação de nenhum dos participantes.

Você tem o direito de ser mantido atualizado sobre os resultados parciais da pesquisa e, caso seja solicitado, darei todas as informações de que precisas.

Eu me comprometo a utilizar os dados coletados somente para o estudo e escrita da dissertação de mestrado, podendo o resultado desse trabalho resultar em artigos científicos e publicação em revistas especializadas e/ou em encontros científicos e congressos, sem nunca tornar possível sua identificação, garantindo total anonimato.

No verso desta folha, está o termo de consentimento livre e esclarecido para ser assinado caso não tenha ficado dúvida e você concorde em participar.

Agradeço, antecipadamente sua participação, pois esta contribuirá de forma significativa para o delinear deste estudo, o qual tem como finalidade profissional de contribuir com as Políticas Públicas e Gestão da Educação Profissional e Tecnológica.

Atenciosamente, 


\section{Apêndice C -Termo de Consentimento Livre e Esclarecido-TCLE (assinado pelo professor)}

Acredito ter sido suficientemente informado (a) a respeito das informações que li, a respeito do estudo sobre "Docência na EPT-Educação Profissional e Tecnológica. Com a finalidade de analisar a percepção sobre a formação docente e suas implicações no processo ensino-aprendizagem dos alunos dos cursos técnicos no IFPA-Campus Conceição do Araguaia.

Ficaram claras para mim quais são os procedimentos a serem realizados, as garantias de confidencialidade e anonimato e de esclarecimentos permanentes.

Ficou claro também que minha participação é isenta de despesas e que tenho garantia do acesso aos resultados e de esclarecer minhas dúvidas em qualquer tempo.

Concordo voluntariamente em participar deste estudo, sabendo que poderei retirar o meu consentimento a qualquer momento, antes ou durante o mesmo, sem penalidade, prejuízo ou perda de qualquer benefício que eu possa ter adquirido anteriormente ao estudo.

Portanto, tendo sido orientado (a) quanto ao teor aqui mencionado e compreendido a natureza e o objetivo do já referido estudo, manifeste seu livre consentimento em participar, assinando abaixo, o qual servirá apenas como documento e registro da pesquisa, estritamente de cunho acadêmico.

Obrigada pela Colaboração!

Rosilândia Ferreira de Aguiar

Mestranda/Pesquisadora

Assinatura do livre consentimento: 


\title{
Apêndice D - Roteiro da Entrevista realizada com 06(seis) docentes.
}

\author{
Identificação \\ Prof. \\ Idade: \\ Sexo:

\section{I - PROCESSO FORMATIVO}

1. Como se deu seu processo de formação? Fale-nos desde a conclusão do ensino médio até a última formação. Quais curso? Período? E onde os realizou?

2. Como foi a escolha de seu curso de graduação e pós-graduação, as expectativas em relação a ele, suas impressões gerais sobre sua formação e se você tinha pretensão de se tornar professor?

\section{II - ATUAÇÃO E TRAJETÓRIA PROFISSIONAL}

1. Antes do início na carreira do magistério, você teve experiências profissionais? Essa atuação foi na área de sua graduação? Em caso negativo, porque não exerceu nenhuma atividade na área de formação? Você sentiu falta de ter tido esta experiencia antes de atuar como professor? Você considera que a experiência profissional na área de formação contribuiu para seu trabalho como professor? Por quê?

2. Há quantos anos você está atuando como professor de EPT? Como foi o início de seu trabalho como professor de cursos técnicos subsequentes em que se baseou para iniciar esse trabalho, qual referência buscou? Que tipos de conhecimentos são base, ou seja, são necessários para ter um bom desempenho como professor? O que você considera que o professor deve saber para ensinar aos alunos dos cursos técnicos? Quais os aspectos positivos e negativos no início de sua carreira como professor de EPT?

3. Para atuar na EPT como docente lhe foi oferecida uma preparação? Algum curso de formação pedagógica? Qual sua opinião, sobre esse início na carreira? Você considera importante a formação pedagógica para o desenvolvimento de sua prática docente?

4. Além da docência, você atua em outros cargos administrativos na instituição? Qual? Você não se sente sobrecarregado? Tem conseguido desempenhar todas as funções sem prejuízos de nenhuma delas e ou até mesmo de cunho pessoal?

5. Como você analisa suas condições de trabalho na instituição?

\section{III - PRÁTICAS PEDAGÓGICAS E O CONTEXTO INSTITUCIONAL}

1. O que você considera uma boa prática pedagógica? Que conhecimentos/saberes você considera fundamentais para a sua prática de ensino na sala de aula?

2. Como você seleciona/organiza o conteúdo a ser ensinado, em que se baseia para fazer estas atividades? Qual critério utiliza para selecionar o material didático, método ou estratégias de ensino que vai utilizar para ministrar o conteúdo? Elabora material para os alunos? Ou de que forma o aluno acompanha o conteúdo ensinado?

3. Como acontece o processo avaliativo em suas aulas? Quais instrumentos para avaliação? Em sua opinião a avaliação dos alunos serve para quê? Você costuma dar o feedback dessas avaliações, como faz isso?

4. Quais são os fatores que afetam o processo ensino-aprendizagem? Como você lida com dificuldades de aprendizagem? O que você faz quando percebe que um aluno não aprendeu?

5. Como se dá a organização das aulas práticas e das visitas técnicas? Na sua opinião elas são necessárias? O que facilita e o que dificulta nesse processo? Em todas as suas aulas você consegue estabelecer uma articulação da teoria com a prática?

6. Como se dá seu relacionamento com os alunos em sala de aula? Você considera importante ter uma interação, aproximação, além da sala de aula?

7. Você considera que a formação que os alunos recebem na Instituição são suficientes e os prepara para atuar no mundo do trabalho?

8. Para finalizar, como você percebe o exercício da docência na EPT? A instituição lhe oportuniza momentos de formação continuada e de reflexão sobre a prática pedagógica? $\mathrm{O}$ que a Instituição poderia estar promovendo para aperfeiçoar sua formação docente, visando o aprimoramento do trabalho docente e à melhoria do processo ensino-aprendizagem? 


\section{Apêndice E- Carta ao discente convidando-o a participar da pesquisa e preenchimento do questionário.}

Prezado (a) Aluno (a),

Como mestranda, estou desenvolvendo uma pesquisa que objetiva identificar a percepção dos alunos do IFPA-Campus Conceição do Araguaia, sobre o processo de ensinoaprendizagem ofertado na Instituição.

Gostaria de convidá-lo (a) a colaborar de forma voluntária conosco. Para isso, foi criado um questionário com perguntas específicas sobre o assunto a ser estudado. As respostas a essas questões não terão qualquer interferência ou questionamento de minha parte.

Não existirão despesas ou compensações financeiras para nenhum participante em qualquer fase do estudo. A qualquer momento, você pode obter qualquer esclarecimento sobre o estudo, bem como desistir de participar do mesmo, sem qualquer prejuízo.

Você tem a garantia de que as informações obtidas por meio do questionário serão analisadas por mim, não sendo divulgada, em hipótese alguma, a identificação de nenhum dos participantes e nem dos nomes dos professores citados nas respostas.

Eu me comprometo a utilizar os dados coletados somente para a dissertação. No caso, de publicação desse trabalho e ou produção de artigos científicos em revistas especializadas e/ou em encontros científicos e congressos, poderás ficar seguro que não haverá identificação pessoal de nenhum dos participantes ou nomes de professores citados, garantindo total anonimato. Para isso, teremos todo cuidado e uma ética ao tratar os dados coletados.

Abaixo está o Termo de Consentimento Livre e Esclarecido para ser lido e, caso não tenha ficado dúvida e você concorde em participar apenas responda e ao, finalizar o questionário clique em ENVIAR que será direcionado para minha conta no Google Drive.

Qualquer dúvida entre em contato somente comigo pelo e-mail: rosilandia.aguiar@hotmail.com ou pelo celular: (94) 991471136 ou (94) 981341826.

Agradeço antecipadamente sua participação e aguardo o mais rápido possível o envio de suas respostas.

Atenciosamente, 


\section{Apêndice F - Termo de Consentimento Livre e esclarecido -TCLE (enviado ao aluno)}

Acredito ter sido suficientemente esclarecido (a) a respeito das informações que li, sobre este estudo. Ficaram claros os procedimentos a serem realizados, garantias de confidencialidade, anonimato e esclarecimentos permanentes.

Ficou claro que minha participação é isenta de despesas e que tenho garantia do acesso aos resultados e de esclarecer minhas dúvidas em qualquer tempo.

Concordo voluntariamente em participar deste estudo, sabendo que poderei retirar o meu consentimento a qualquer momento, antes ou durante o mesmo, sem penalidade e ou prejuízo.

Sendo assim, em reposta ao convite, dou meu consentimento respondendo o Questionário/formulário online do google forms e ENVIANDO a mestranda/pesquisadora. 


\section{Apêndice G - Questionário enviado aos 15 alunos dos cursos técnicos subsequentes.}

Prezado aluno (a) Esta pesquisa tem o objetivo de identificar a percepção de vocês quanto ao processo de ensino- aprendizado vivenciado no curso que você frequenta no IFPACampus Conceição do Araguaia.

Por gentileza, responda com sinceridade as questões propostas. Sua opinião é muito importante e contribuirá para o estudo que estamos realizando, dissertação de Mestrado, sobre a influência da Formação do Professor de Educação Profissional e Tecnológica no processo de ensino-aprendizagem dos alunos dos cursos técnicos subsequentes.

1. Qual curso técnico você frequenta no IFPA-Campus Conceição do Araguaia? Texto Ajuda: Curso técnico que você está matriculado no ano de 2015.

2. Além de frequentar este curso no IFPA, você atualmente está estudando outro curso em outra Instituição?

Texto Ajuda: Se sim, qual Curso, Instituição e respectivo horário?

3. Qual seu Nome? Qual seu gênero? Masculino ou Feminino? Em qual faixa etária, você se encontra?

4. Qual módulo ou semestre do curso você está frequentando?

Texto de Ajuda: Informe o período em que estava FREQUENTANDO antes de iniciar a greve dos professores.

5. Qual nível de escolaridade você tem concluído?

Texto de Ajuda: Marcar o nível de escolaridade mais alto que você CONCLUIU entre as opções abaixo.

6. Atualmente você está exercendo alguma atividade profissional?

Texto de Ajuda: Marcar sua ocupação, além dos estudos, ou seja, se você possui trabalho formal ou informal.

7. Por que escolheu fazer o Curso Técnico?

Texto de Ajuda: Você pode ficar a vontade para expressar o motivo que o levou a escolher o curso. Quais eram as expectativas em relação a este curso. E se essas expectativas estão sendo atendidas ou não e por quê?

8. As aulas dos professores são planejadas e dinâmicas?

Texto de Ajuda: Percebes se os professores planejaram as aulas para facilitar o aprendizado de cada aluno? O professor utiliza várias estratégias de ensino, recursos didáticos e atividades visando a construção do conhecimento por parte de todos os alunos? Você pode até identificar o professor que haverá sigilo absoluto e facilitará a análise desta pesquisa.

9. Como se dá o relacionamento professor e aluno?

Texto Ajuda: O professor tem lhe assistido em momento extra sala para sanar suas dificuldades, você percebe uma compreensão do professor dos aspectos psicológicos e sociais envolvidos nesse processo de ensino-aprendizagem? 
10. Quando o professor percebe que os alunos não estão aprendendo o que está sendo ensinado, ele muda a maneira de apresentar os conteúdos?

Texto Ajuda: O professor demonstra preocupação em ajudar o aluno que tem dificuldades em assimilar os conteúdos? Ele retoma, faz revisão do conteúdo do Ensino Médio para que haja compreensão do conteúdo a ser ensinado?

\section{Existem visitas Técnicas?}

Texto Ajuda: Visitas técnicas é o momento que você vai visitar as empresas ou instituições para conhecer seu dia-a-dia e ouvir do técnico que lá trabalha como se dá o desenvolvimento de determinada atividade. Então, a Instituição propicia oportunidades, além da sala de aula, para enriquecer seu aprendizado?

12. Em todas as disciplinas, tem aulas práticas?

Texto Ajuda: Em todas as disciplinas o professor estabelece articulação teoria/prática? Tem havido momento de aplicar o que você aprendeu de forma a reforçar e dar vida ao seu aprendizado? Como isso acontece em sala e no laboratório? Relate as principais dificuldades.

13. Como acontece o processo avaliativo? Quais os instrumentos utilizados pelo professor para a avaliação da aprendizagem?

Texto Ajuda: O professor utiliza variadas formas? Tem o hábito de dar retorno dessas avaliações para esclarecer o que não foi demonstrado no momento da verificação do aprendizado ou apenas o utiliza para dar nota?

14. Alguma situação que influencia em seu aprendizado que não foi contemplada que você gostaria de relatar?

Texto Ajuda: Poderá, inclusive, apresentar alguma sugestão para melhorar seu aprendizado. 